Prepared in cooperation with the Arkansas Natural Resources Commission and the Arkansas Geological Survey

\title{
Water Levels and Selected Water-Quality Conditions in the Sparta-Memphis Aquifer (Middle Claiborne Aquifer) in Arkansas, Spring-Summer 2007
}

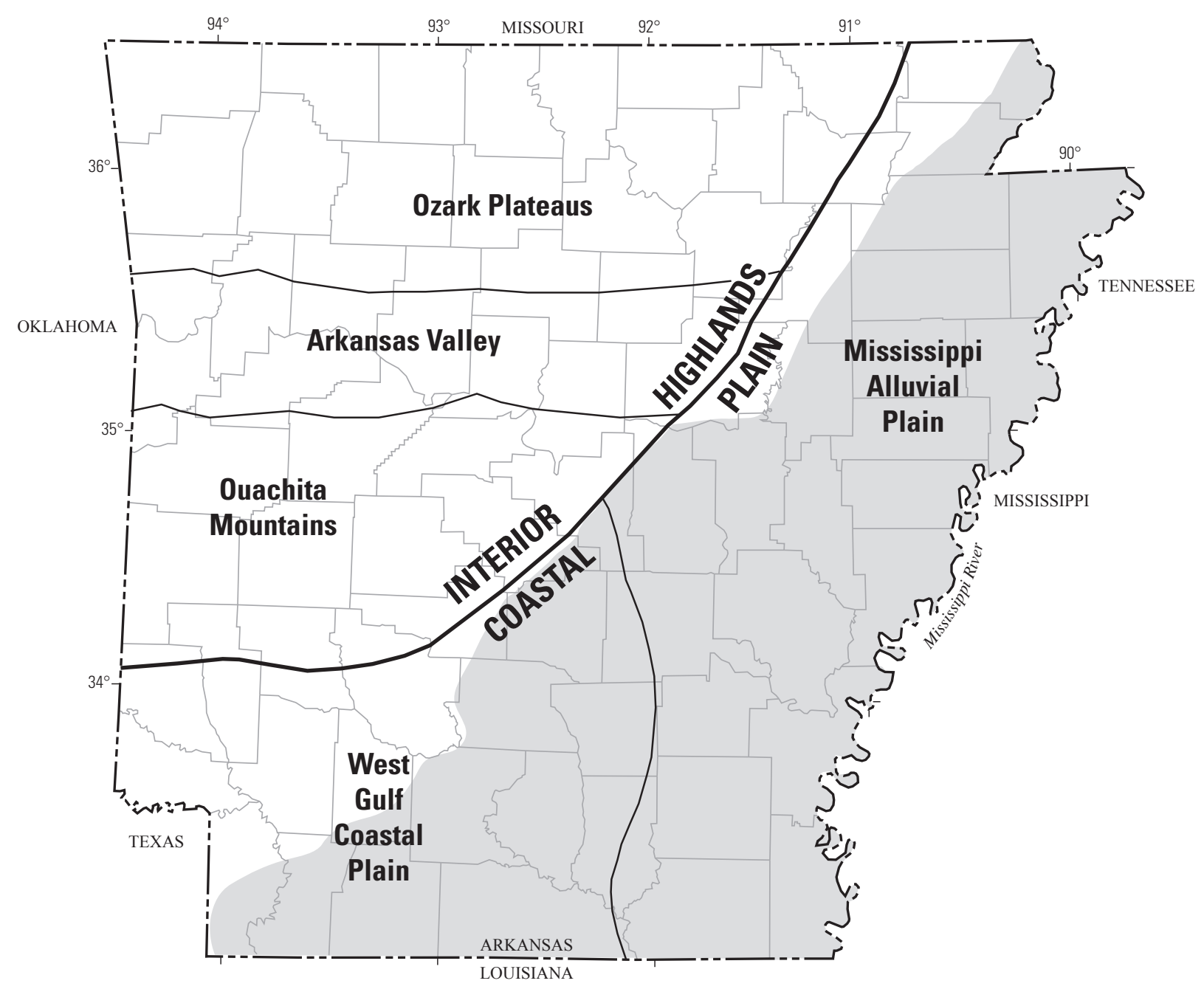

Scientific Investigations Report 2009-5207 


\section{Water Levels and Selected Water-Quality Conditions in the Sparta-Memphis Aquifer (Middle Claiborne Aquifer) in Arkansas, Spring-Summer 2007}

By T.P. Schrader

Prepared in cooperation with the Arkansas Natural Resources Commission and the Arkansas Geological Survey

Scientific Investigations Report 2009-5207 


\section{U.S. Department of the Interior \\ KEN SALAZAR, Secretary \\ U.S. Geological Survey \\ Marcia K. McNutt, Director}

\section{U.S. Geological Survey, Reston, Virginia: 2009}

For product and ordering information:

World Wide Web: http://www.usgs.gov/pubprod

Telephone: 1-888-ASK-USGS

For more information on the USGS--the Federal source for science about the Earth, its natural and living resources, natural hazards, and the environment:

World Wide Web: http://www.usgs.gov

Telephone: 1-888-ASK-USGS

Any use of trade, product, or firm names is for descriptive purposes only and does not imply endorsement by the U.S. Government.

Although this report is in the public domain, permission must be secured from the individual copyright owners to reproduce any copyrighted materials contained within this report.

Suggested citation:

Schrader, T.P., 2009, Water levels and selected water-quality conditions in the Sparta-Memphis aquifer (middle Claiborne aquifer) in Arkansas, spring-summer 2007: U.S. Geological Survey Scientific Investigations Report 2009-5207, $50 \mathrm{p}$. 


\section{Contents}

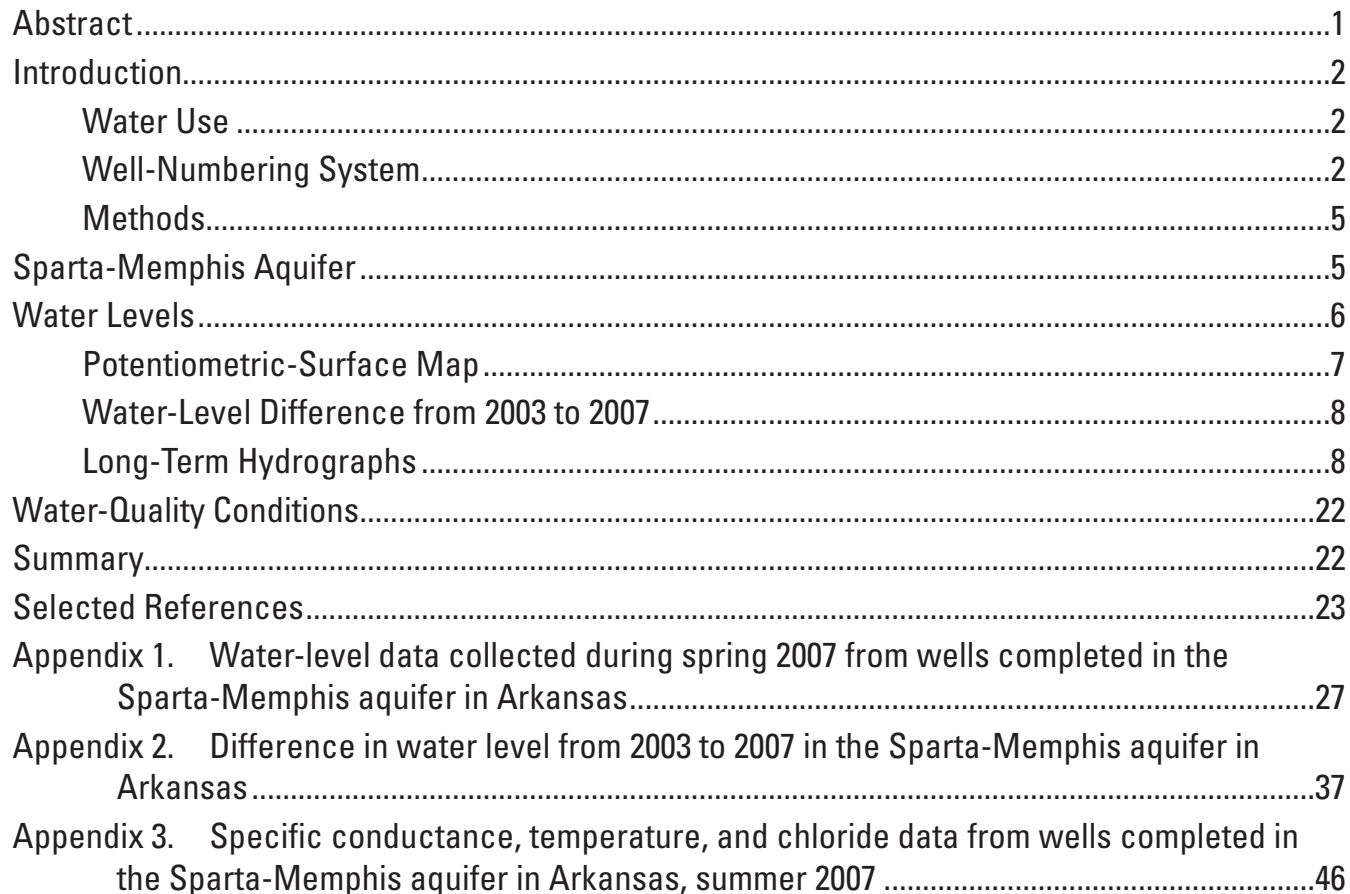

\section{Plates}

[In pocket]

1-3. Maps showing:

1. Potentiometric surface of the Sparta-Memphis aquifer in Arkansas, spring 2007

2. Water-level difference for the Sparta-Memphis aquifer in Arkansas from 2003 to 2007

3. Specific conductance for the Sparta-Memphis aquifer in Arkansas, 2007

\section{Figures}

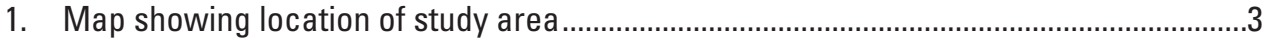

2. Graph showing water use in the Sparta-Memphis aquifer in Arkansas, 1965-2005 .........4

3. Diagram showing well-numbering system.....................................................................

4. Graphs showing water-level hydrographs for selected wells completed in the Sparta-

Memphis aquifer in Arkansas.

\section{Tables}

1. Stratigraphic correlation of the northern and southern parts of Arkansas for the study area

2. Statistical summary of annual rise-decline in water level by county for wells in the Sparta-Memphis aquifer, 1983-2007 


\section{Conversion Factors and Datums}

\begin{tabular}{lll}
\hline \multicolumn{1}{c}{ Multiply } & \multicolumn{1}{c}{ By } & \multicolumn{1}{c}{ To obtain } \\
\hline foot $(\mathrm{ft})$ & Length & \\
mile $(\mathrm{mi})$ & 0.3048 & meter $(\mathrm{m})$ \\
\hline & 1.609 & kilometer $(\mathrm{km})$ \\
\hline million gallons per day $(\mathrm{Mgal} / \mathrm{d})$ & Flow rate & \\
foot per year $(\mathrm{ft} / \mathrm{yr})$ & 0.04381 & cubic meters per second $\left(\mathrm{m}^{3} / \mathrm{s}\right)$ \\
\hline
\end{tabular}

Temperature in degrees Celsius $\left({ }^{\circ} \mathrm{C}\right)$ may be converted to degrees Fahrenheit $\left({ }^{\circ} \mathrm{F}\right)$ as follows:

${ }^{\circ} \mathrm{F}=\left(1.8 x^{\circ} \mathrm{C}\right)+32$

Temperature in degrees Fahrenheit $\left({ }^{\circ} \mathrm{F}\right)$ may be converted to degrees Celsius $\left({ }^{\circ} \mathrm{C}\right)$ as follows:

${ }^{\circ} \mathrm{C}=\left({ }^{\circ} \mathrm{F}-32\right) / 1.8$

Vertical coordinate information is referenced to the National Geodetic Vertical Datum of 1929 (NGVD 1929).

Horizontal coordinate information is referenced to the North American Datum of 1983 (NAD 1983).

Altitude as used in this report, refers to distance above the vertical datum.

Specific conductance is given in microsiemens per centimeter at 25 degrees Celsius $\left(\mu \mathrm{S} / \mathrm{cm}\right.$ at $25^{\circ} \mathrm{C}$ ).

Concentrations of chemical constituents in water are given in milligrams per liter $(\mathrm{mg} / \mathrm{L})$ or micrograms per liter $(\mu \mathrm{g} / \mathrm{L})$. 


\title{
Water Levels and Selected Water-Quality Conditions in the Sparta-Memphis Aquifer (Middle Claiborne Aquifer) in Arkansas, Spring-Summer 2007
}

\author{
By T.P. Schrader
}

\section{Abstract}

The U.S. Geological Survey in cooperation with the Arkansas Natural Resources Commission and the Arkansas Geological Survey has monitored water levels in the Sparta Sand of Claiborne Group and Memphis Sand of Claiborne Group (herein referred to as the Sparta Sand and the Memphis Sand, respectively), since the 1920s. Groundwater withdrawals have increased while water levels have declined since monitoring was initiated. Herein, aquifers in the Sparta Sand and Memphis Sand will be referred to as the Sparta-Memphis aquifer throughout Arkansas. During the spring of 2007, 309 water levels were measured in wells completed in the SpartaMemphis aquifer. During the summer of 2007, 129 waterquality samples were collected and measured for temperature and specific conductance and 102 were collected and analyzed for chloride from wells completed in the Sparta-Memphis aquifer.

Water-level measurements collected in wells screened in the Sparta-Memphis aquifer were used to produce a regional potentiometric-surface map. The regional direction of groundwater flow in the Sparta-Memphis aquifer is generally to the south-southeast in the northern half of Arkansas and to the east and south in the southern half of Arkansas, away from the outcrop area except where affected by large ground-water withdrawals. The highest water-level altitude measured in the Sparta-Memphis aquifer was 326 feet above National Geodetic Vertical Datum of 1929, located in Grant County in the outcrop at the western boundary of the study area; the lowest water-level altitude was 161 feet below National Geodetic Vertical Datum of 1929 in Union County near the southern boundary of the study area.

Eight cones of depression (generally represented by closed contours) are located in the following counties: Bradley, Drew, and Ashley; Calhoun; Cleveland; Columbia; Crittenden; Arkansas, Jefferson, and Lincoln; Cross and Poinsett; and Union. Two large depressions are shown on the 2007 potentiometric-surface map, centered in Jefferson and Union Counties, as a result of large withdrawals for industrial and public supplies. The depression centered in Jefferson County deepened and expanded in recent years into Arkansas and Prairie Counties as a result of large withdrawals for irrigation and public supply. The area enclosed within the 40 -foot contour has expanded on the 2007 potentiometric-surface map when compared with the 2005 potentiometric-surface map. In 2003, the depression in Union County was elongated east and west and beginning to coalesce with the depression in Columbia County. The deepest measurement during 2007 in the center of the depression in Union County has risen 38 feet since 2003. The area enclosed by the deepest contour, 160 feet below National Geodetic Vertical Datum of 1929, on the 2007 potentiometric-surface map is less than 10 percent of the area on the 2005 potentiometric-surface map. A broad depression in western Poinsett and Cross Counties was first shown in the 1995 potentiometric-surface map caused by withdrawals for irrigation extending north to the Poinsett-Craighead County line, and south into Cross County.

A water-level difference map was constructed using the difference between water-level measurements made during 2003 and 2007 from 283 wells. The difference in water level between 2003 and 2007 ranged from -49.8 to 60.0 feet. Areas with a general rise in water levels are shown in northern Arkansas, Columbia, southern Jefferson, and most of Union Counties. In the area around west-central Union County, water levels rose as much as 60.0 feet with water levels in 15 wells rising 20 feet or more, which is an average annual rise of 5 feet or more. Water levels generally declined throughout most of the rest of Arkansas.

Hydrographs from 157 wells were constructed with a minimum of 25 years of water-level measurements. During the period 1983-2007, the county mean annual water level rose in Calhoun, Columbia, Hot Spring, and Lafayette Counties. Mean annual declines between 0.0 and 2.1 feet per year occurred in all other counties. In western Arkansas County, a hydrograph shows a 60 -foot seasonal change in water level for the 2 years shown. The period of the 60 -foot decline in water level coincides with the spring-summer irrigation season.

Specific conductance ranged from 35 microsiemens per centimeter at 25 degrees Celsius $(\mu \mathrm{S} / \mathrm{cm})$ in Ouachita County to $1,280 \mu \mathrm{S} / \mathrm{cm}$ at two wells in Monroe County. The mean 
specific conductance was $398 \mu \mathrm{S} / \mathrm{cm}$ and the median specific conductance was $334 \mu \mathrm{S} / \mathrm{cm}$. Dissolved chloride concentrations ranged from 1.2 milligrams per liter $(\mathrm{mg} / \mathrm{L})$ in Lincoln County to $308 \mathrm{mg} / \mathrm{L}$ in Monroe County. The mean dissolved chloride concentration was $28.6 \mathrm{mg} / \mathrm{L}$ and the median dissolved chloride concentration was $8.7 \mathrm{mg} / \mathrm{L}$. Although there is a regional increase in specific conductance to the east and south, anomalous increases occur in some parts of the study area. Large specific conductance values (greater than $700 \mu \mathrm{S} /$ $\mathrm{cm}$ and less than $1,300 \mu \mathrm{S} / \mathrm{cm}$ ) occur in samples from wells in Arkansas, Ashley, Monroe, Phillips, and Union Counties.

\section{Introduction}

The U.S. Geological Survey (USGS) in cooperation with the Arkansas Natural Resources Commission and the Arkansas Geological Survey has monitored water levels in the Sparta Sand of Claiborne Group and Memphis Sand of Claiborne Group (herein referred to as the Sparta Sand and the Memphis Sand, respectively), since the 1920s. Groundwater withdrawals have increased while water levels have declined since monitoring was initiated. The USGS has produced reports, at various periodic schedules, discussing the groundwater conditions of the Sparta Sand and Memphis Sand aquifers in Arkansas from a continuing project that includes the groundwater networks and basic data collection for Arkansas to provide information for the management of this valuable resource.

This report presents a status of water levels and waterquality conditions in the aquifers in the Sparta Sand and the Memphis Sand in Arkansas. Herein, aquifers in the Sparta Sand and Memphis Sand will be referred to as the SpartaMemphis aquifer throughout Arkansas. During the spring of 2007, water levels were measured in 309 wells completed in the Sparta-Memphis aquifer. These measurements were used to describe the potentiometric surface of the Sparta-Memphis aquifer. During the summer of 2007, 129 water-quality samples were collected and measured for temperature and specific conductance, and 102 were collected and analyzed for chloride. This report presents a potentiometric-surface map, a water-level difference map comparing water levels from 2003 to 2007 , selected water-level hydrographs, a specific-conductance map, and water-level and water-quality data tables.

The study area (fig. 1) in Arkansas is bounded on the north by the Missouri State line, on the east by the Tennessee and Mississippi State lines, and on the south by the Louisiana State line. The western boundary is defined as the western extent of the outcrop and subcrop (Hosman, 1982) of the Sparta Sand and the Memphis Sand. Water levels in the aquifer in the Sparta Sand generally correlate with those in the aquifer in the Memphis Sand; therefore, the water-bearing formations are considered to be one hydrologic unit (Stanton, 1997).

\section{Water Use}

Water use in the Sparta-Memphis aquifer in Arkansas generally has increased from 1965 to 2000 (fig. 2). In 1965, water use in the Sparta-Memphis aquifer was about 112 million gallons per day $(\mathrm{Mgal} / \mathrm{d})$, increasing to $142 \mathrm{Mgal} / \mathrm{d}$ in 1970, $144 \mathrm{Mgal} / \mathrm{d}$ in 1975, and $185 \mathrm{Mgal} / \mathrm{d}$ in 1980 (Halberg, and Stephens, 1966; Halberg, 1972, Halberg, 1977, Holland and Ludwig, 1981). In 1985, water use declined to about 157 Mgal/d (Holland, 1987). Water use in the Sparta-Memphis aquifer was about $223 \mathrm{Mgal} / \mathrm{d}$ in 1990 and $284 \mathrm{Mgal} / \mathrm{d}$ in 1995 (Holland, 1993, 1999). In 2000, water use in the SpartaMemphis aquifer was about $287 \mathrm{Mgal} / \mathrm{d}$ (Holland, 2004), an increase of about 156 percent from 1965. In 2005, water use in the Sparta-Memphis aquifer declined to about $170 \mathrm{Mgal} / \mathrm{d}$ (Holland, 2007).

Water use from the Sparta-Memphis aquifer in 2005 was divided into three primary categories - irrigation, public supply, and industrial. Irrigation used about $61.0 \mathrm{Mgal} / \mathrm{d}$ (35.9 percent), public supply used about $58.9 \mathrm{Mgal} / \mathrm{d}$ (34.6 percent), and industrial used about $48.0 \mathrm{Mgal} / \mathrm{d}$ (28.2 percent). Agriculture and power generation each accounted for less than 1 percent of the water use in the Sparta-Memphis aquifer in Arkansas in 2005. Major pumping centers that use the SpartaMemphis aquifer for public supply and industry occur in Columbia, Jefferson, and Union Counties. Arkansas, Craighead, Cross, Desha, Lonoke, Monroe, Phillips, and Prairie Counties accounted for the majority of the water withdrawn for irrigation from the Sparta-Memphis aquifer in 2005 (Holland, 2007).

\section{Well-Numbering System}

The well-numbering system used in this report is based upon the location of the wells according to the Federal land survey used in Arkansas. The component parts of a well number are the township designation; the range designation; the section number; three-letter designation that indicates, respectively, the quarter section, the quarter-quarter section, and the quarter-quarter-quarter section in which the well is located; and the sequence number of the well in the quarter-quarterquarter section. The letters are assigned counterclockwise, beginning with " $\mathrm{A}$ " in the northeast quarter or quarter-quarter or quarter-quarter-quarter section in which the well is located. For example, well 01S03W04BBD16 (fig. 3) is located in Township 1 South, Range 3 West, in the southeast quarter of the northwest quarter of the northwest quarter of section 4 . This well is the 16th well in this quarter-quarter-quarter section of section 4 from which data were collected. 


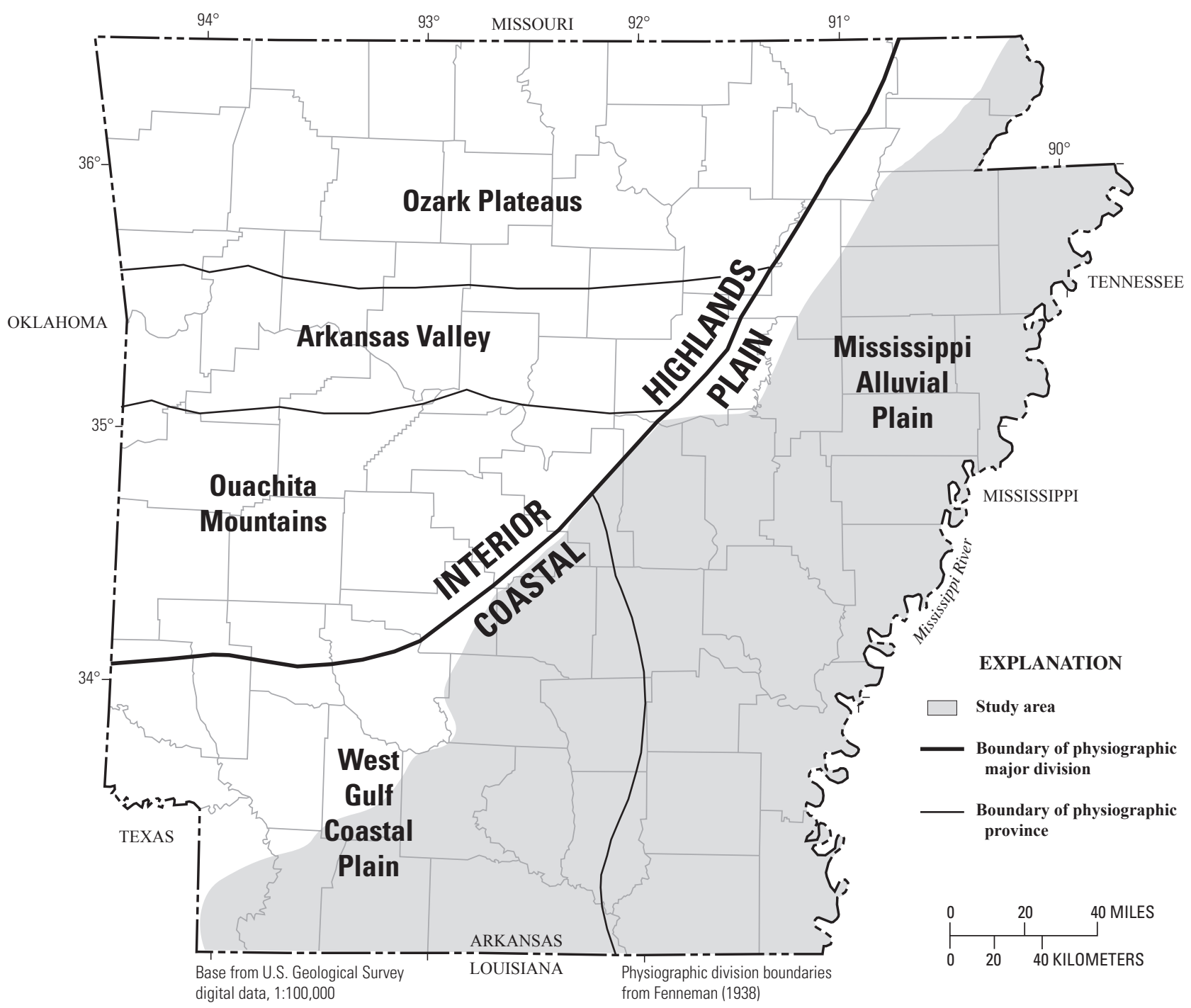

Figure 1. Location of study area. 


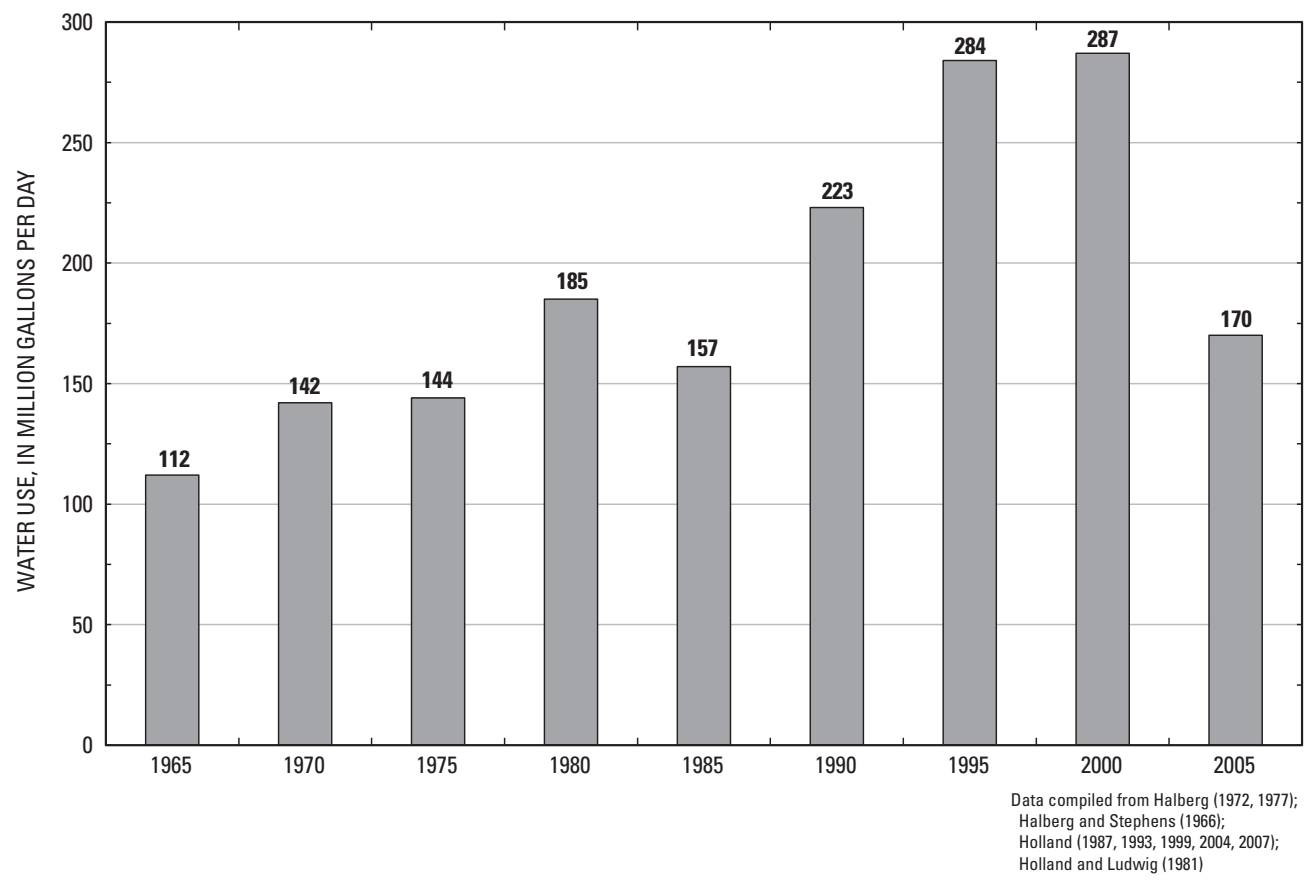

Figure 2. Water use in the Sparta-Memphis aquifer in Arkansas, 1965-2005.

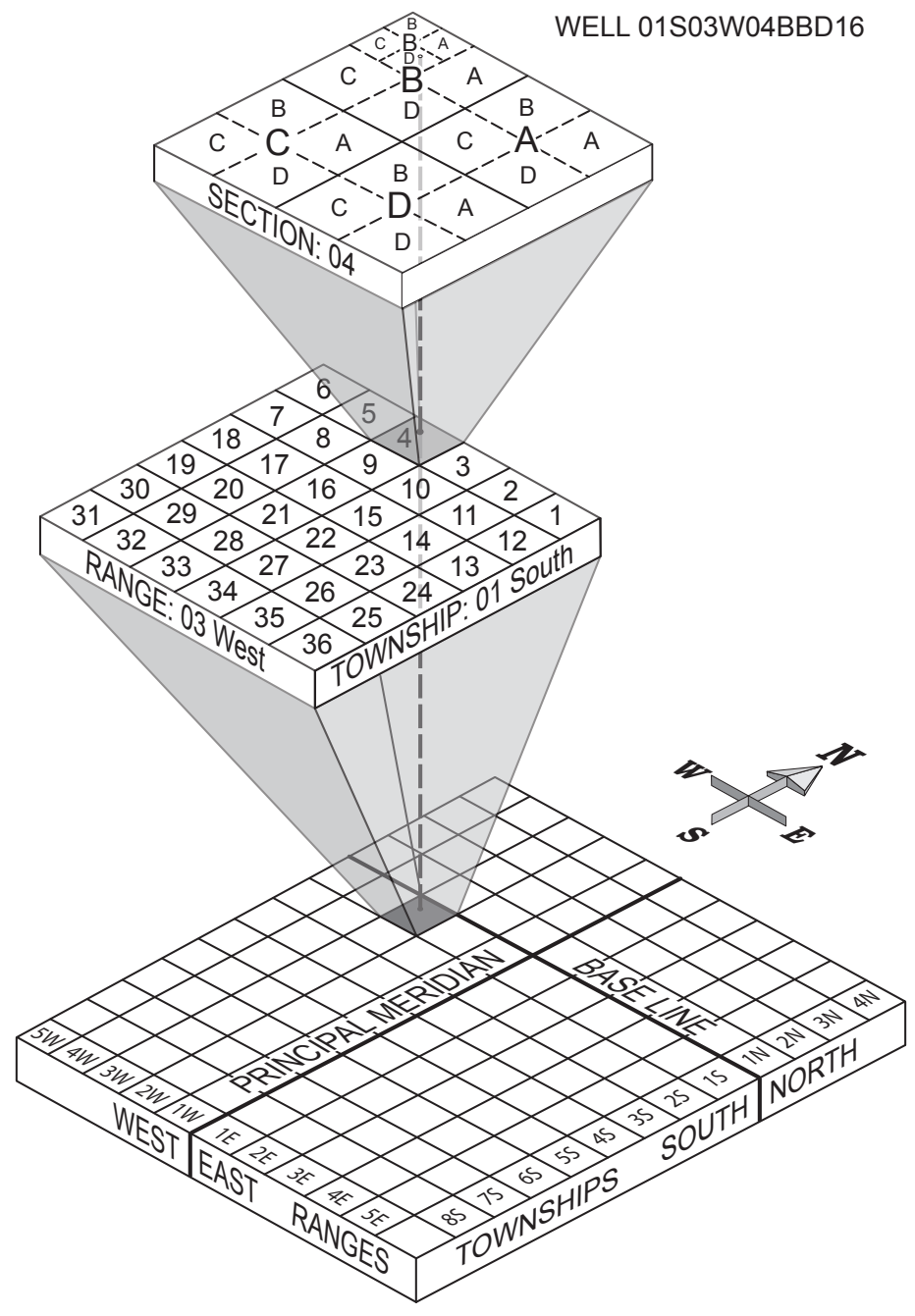

Figure 3. Well-numbering system. 


\section{Methods}

USGS personnel measured water levels from February 2007 to April 2007 from wells completed in the SpartaMemphis aquifer. Measurements were made using steel or electric tapes graduated in hundredths of a foot. The steel and electric tapes were calibrated prior to collecting water-level measurements. Calibration was performed by comparing the steel or electric tapes to a standardized steel tape used only for calibration.

Well locations were verified using Global Positioning System (GPS) receivers to acquire the horizontal-coordinate information, latitude and longitude, based on the North American Datum of 1983. The latitude and longitude of the wells in Arkansas were recorded from a GPS receiver accurate to one-tenth of a second of latitude and longitude (approximately 10-20 feet (ft)). The latitude and longitude of the well location were transferred to a topographic map and the altitude of the well (National Geodetic Vertical Datum of 1929) was determined from the topographic contours at the location on the map. Altitude is accurate to about one-half of the contour interval ( 2.5 to $5 \mathrm{ft}$ ) of the topographic map.

Two methods for calculating the annual rise or decline of water levels are used. One method is to take the difference between the final and initial water levels and divide by the period of time. This method uses two measurements and calculated values are dependent solely on the final and initial water levels. A second method uses the linear regression of water levels and time of measurement to calculate the annual rise or decline in water level. Linear regression is more robust because it includes all the measurements to determine the trend line, resulting in a value that is dependent on all water levels during the period of record. The slope, $\beta$, of the line is the annual rise or decline in water level. The intercept, $\beta_{0}$, would be the water level in the year 1900, the origin for the graph. This requires the assumption that the pumping rate was constant throughout the period of pumping. This condition is not commonly met or the data are not available to demonstrate this has occurred. The predevelopment water level will not be discussed as this condition can not be demonstrated. The $\mathrm{R}^{2}$ term is the coefficient of determination, correlation coefficient, or the fraction of variance explained by the regression. The $\mathrm{R}^{2}$ value gives the proportions of the total variability that can be accounted by the independent variable (Helsel and Hirsch, 1992). Values of $R^{2}$ can range from 0.00 to 1.00. A large value of $\mathrm{R}^{2}$ can indicate a linear change in water level. A low value of $\mathrm{R}^{2}$ can indicate a sporadic change in water level.

Five assumptions are associated with linear regression: (1) $\mathrm{Y}$ is linearly related to $\mathrm{X}$, (2) data used to fit the linear regression are representative of data of interest, (3) variance of the residuals is constant and does not depend on $\mathrm{X}$ or on anything else, (4) the residuals are independent, and (5) the residuals are normally distributed. The assumption of a normal distribution is involved only when testing hypotheses, requiring the residuals from the regression equation to be normally distributed (Helsel and Hirsch, 1992).

Water-quality samples were collected for specificconductance, temperature, and chloride analysis using the procedures described in the "National Field Manual for the Collection of Water-Quality Data" (U.S. Geological Survey, variously dated). Wells were purged a minimum of three-casing volumes. During the well purge, specific conductance and temperature were monitored until measurements stabilized. If the specific conductance and temperature were fluctuating after three volumes, the well purge continued until specificconductance and temperature values stabilized to ensure a representative sample. Chloride samples were analyzed by the USGS National Water Quality Laboratory. The analytical method was an ion-exchange chromatography, lab schedule 1571, method code IC022 (Fishman and Friedman, 1989).

Specific-conductance data were measured from selected wells using specific-conductance meters with temperature compensation. Specific-conductance meters were calibrated twice daily by comparing the measurement of two specific conductance calibration standards. Specific conductance is a measure of the electrical conductance of a solution. As the dissolved-solids concentration in groundwater increases, specific conductance increases. Most of the wells sampled were public supply and industrial wells.

\section{Sparta-Memphis Aquifer}

The Sparta-Memphis aquifer is a hydrologic unit within the Mississippi Embayment aquifer system that covers parts of seven states. Water use from the aquifer is large in four states: Arkansas, Louisiana, Mississippi, and Tennessee. Three states, Alabama, Kentucky, and Missouri, withdraw smaller amounts of water from the aquifer. Within the Mississippi Embayment the name for the Sparta-Memphis aquifer can vary depending on the location, which may include the Sparta Sand, Memphis Sand, 500-foot Sand, and the Lisbon Formation. The name used in the Mississippi Embayment aquifer system is the middle Claiborne aquifer (Hart and others, 2008).

The Sparta Sand and Memphis Sand (table 1) of Eocene age mainly consist of fine to medium sand in Arkansas. Some silt, clay, and lignite occur in the upper part of the Sparta Sand and Memphis Sand. Sands in the Sparta Sand were deposited by shifting streams on a deltaic-fluvial flood plain (Payne, 1968). These sands mostly are interconnected, but separately identifiable sands can be traced for short distances (Snider and others, 1972). The Cook Mountain Formation of Claiborne Group overlies the Sparta Sand and Memphis Sand and serves as an upper confining unit (table 1). The permeable units of the Sparta Sand and the Memphis Sand compose the Sparta and Memphis aquifers. In this report, the aquifers are referred to as the Sparta-Memphis aquifer throughout the study area. 
Table 1. Stratigraphic correlation of the northern and southern parts of Arkansas for the study area.

[Modified from Hosman and Weiss, 1991]

\begin{tabular}{|c|c|c|c|}
\hline Epoch & Group & $\begin{array}{c}\text { Formations in the southern } \\
\text { part of Arkansas }\end{array}$ & $\begin{array}{c}\text { Formations in the northeastern } \\
\text { part of Arkansas }\end{array}$ \\
\hline \multirow{6}{*}{ Eocene } & Jackson & Undifferentiated & Undifferentiated \\
\hline & \multirow{5}{*}{ Claiborne } & Cockfield Formation & Cockfield Formation \\
\hline & & Cook Mountain Formation & Cook Mountain Formation \\
\hline & & Sparta Sand & \multirow{3}{*}{ Memphis Sand } \\
\hline & & Cane River Formation & \\
\hline & & Carrizo Sand & \\
\hline \multirow{3}{*}{$\begin{array}{c}\text { Upper } \\
\text { Paleocene }\end{array}$} & \multirow{3}{*}{ Wilcox } & \multirow{3}{*}{ Undifferentiated } & Flour Island Formation \\
\hline & & & Fort Pillow Sand \\
\hline & & & Old Breastworks Formation \\
\hline
\end{tabular}

The Sparta Sand is composed of a sequence of alternating sand and clay beds between the massive clays of the overlying Cook Mountain Formation of Claiborne Group and the underlying Cane River Formation of Claiborne Group confining units (Hosman and others, 1968) shown in table 1. The Sparta Sand is in the southern part of the study area (south of about 35 degrees latitude, plate 1) where the Cane River Formation of Claiborne Group is composed predominantly of clay. The Memphis Sand is in the northern part of the study area (north of about 35 degrees latitude), and the Cane River Formation of Claiborne Group or equivalent facies is composed predominantly of sand. Moving south to north in the area, the Cane River Formation undergoes a facies change northward at about 35 degrees latitude, and the marine clays become sand. The transitional zone of interfingering sands and clays is narrow. The northern sand facies of the Cane River Formation is the middle part of the Memphis Sand (Hosman and others, 1968). In the southern area, the Claiborne Group is subdivided into the Carrizo Sand, Cane River Formation, Sparta Sand, Cook Mountain Formation, and the Cockfield Formation (table 1). The equivalent section in the northern area is subdivided into the Memphis Sand, the Cook Mountain Formation, and the Cockfield Formation. The Memphis Sand in the northern area is equivalent to the Carrizo Sand, the Cane River Formation, and the Sparta Sand in the southern area. The Memphis Sand is underlain by a thick layer of clay in the upper part of the Wilcox Group (Hosman and others, 1968).
The Sparta Sand and Memphis Sand generally thicken and groundwater increases in salinity as depth increases to the southeast. The Sparta Sand is 50 to $200 \mathrm{ft}$ thick within the outcrop area (along the western limit) and thickens easterly to nearly $900 \mathrm{ft}$. The Sparta Sand contains freshwater throughout most of its extent in Arkansas. However, saltwater is present in the extreme southeastern part of the State in parts of Ashley, Chicot, and Union Counties (Payne, 1968).

\section{Water Levels}

Water-level measurements in wells screened in the Sparta-Memphis aquifer (appendix 1) were used to produce a regional potentiometric-surface map (plate 1), water-level difference map (plate 2), and hydrographs (fig. 4). Water levels measured during the spring of 2007 were subtracted from water levels measured during the spring of 2003 at selected Sparta-Memphis aquifer wells (appendix 2) and were used to create the water-level difference map. Data from 157 wells that have water-level measurements with a minimum 25-year period of record were used to produce hydrographs compiled by county; hydrographs for 24 of the wells are shown in figure 4. The water levels shown in the hydrographs indicate longterm changes in hydrologic conditions. Long term water-level declines shown in the hydrographs reflect the development of the depressions on the potentiometric surface. 


\section{Potentiometric-Surface Map}

A potentiometric-surface map was constructed using 309 water-level measurements from wells completed in the SpartaMemphis aquifer. Hydrologic principles, water-use data, and historical information were interpreted with the water-level data to delineate the potentiometric-surface contours. The number and location of wells used to construct potentiometricsurface maps differ from year to year. The combined information will result in variations and similarities in potentiometric contours that define the surface depicted on the maps produced in different years.

The potentiometric-surface map of the Sparta-Memphis aquifer shows the altitude of which water would have stood in tightly cased wells completed in the aquifer (plate 1). The map is based upon water-level data collected in 309 wells (appendix 1) in the Sparta-Memphis aquifer during the spring of 2007. The surface is mapped by determining the altitude of the water levels measured in the wells and is represented on the map by contours that connect points of equal water-level altitude. The general direction of groundwater flow in the Sparta-Memphis aquifer is perpendicular to the contours in the direction of decreasing hydraulic gradient.

The natural direction of flow, which historically was eastward and then southward, in the Sparta-Memphis aquifer is altered in areas by large groundwater withdrawals. The regional direction of groundwater flow in the Sparta-Memphis aquifer in 2007 is generally to the south-southeast in the northern half of Arkansas and to the east and south in the southern half of Arkansas, away from the outcrop area except where affected by large groundwater withdrawals. The highest water-level altitude measured in Sparta-Memphis aquifer was $326 \mathrm{ft}$ above NGVD of 1929, located in Grant County in the outcrop at the western boundary of the study area; the lowest water-level altitude was $161 \mathrm{ft}$ below NGVD of 1929 in Union County (appendix 1) near the southern boundary of the study area. The water level at this well in Union County was $14 \mathrm{ft}$ higher than in 2005 (Schrader, 2006).

Eight cones of depression (generally represented by closed contours) are located in the following counties: Bradley, Drew, and Ashley; Calhoun; Cleveland; Columbia; Crittenden; Arkansas, Jefferson, and Lincoln; Cross and Poinsett; and Union. Cones of depression usually are caused by withdrawals rates that exceed the recharge rates within the aquifer over an extended period of time. When a well is pumped, the water level in and around the well declines, creating a depression in the potentiometric surface. Groundwater flows toward the depression at a rate that is proportional to the slope of the depression and the transmissivity of the aquifer; if withdrawal rates exceed the recharge rates to the aquifer, the area of the declining water level expands to form a cone of depression.

Two large cones of depression, centered in Jefferson and Union Counties, are the result of large withdrawals for industrial and public supplies. The cone of depression centered in Jefferson County has deepened and expanded in recent years into Arkansas and Prairie Counties as a result of large withdrawals for irrigation and public supply. This depression is approximately $5 \mathrm{ft}$ shallower in 2007 than in 2005 (Schrader and Jones, 2007). The area enclosed within the $40-\mathrm{ft}$ contour on the 2007 potentiometric-surface map has expanded when compared with the 2005 potentiometric-surface map. The $40-\mathrm{ft}$ contour has extended further east into Arkansas County and further south into Lincoln County. The depression in Union County is roughly circular within the $-60-\mathrm{ft}$ contour. In 2003, this depression was elongated east and west and beginning to coalesce with the depression in Columbia County. Decreasing withdrawals in Columbia and Union Counties have resulted in a separation of these two depressions.

The deepest measured water level in the center of the depression in Union County during 2007 has risen 38 feet since 2003. The location of the deepest water level can vary through time. Changes in pumping rates and well efficiency can affect the location of the deepest water level. The deepest measurement in 2007 is from a different well than the deepest measurement in 2003. On the 2005 potentiometric-surface map, the area enclosed by the deepest contour, $180 \mathrm{ft}$ below NGVD of 1929, is not evident on the 2007 potentiometricsurface map. The area enclosed by the deepest contour, $160 \mathrm{ft}$ below NGVD of 1929 , on the 2007 potentiometricsurface map is less than 10 percent of the area on the 2005 potentiometric-surface map (Schrader and Jones, 2007). The depression in Union County has receded from Union Parish, Louisiana. The -100-ft contour had extended into Union Parish on the 2001 potentiometric-surface map (Schrader, 2004). The -60-ft contour on the 2007 potentiometric-surface map is near the Arkansas-Louisiana State border.

A broad depression in western Poinsett and Cross Counties was first shown in the 1995 potentiometric-surface map (Stanton, 1997) and has been variable in size since 1995. The depression expanded in area in 1997 and 1999, and then decreased in area in 2003 and 2005. In 1995, this depression was enclosed within the 150 -foot contour in the southwestern corner of Poinsett County. In 1997, the depression covered most of the western half of Poinsett County (Joseph, 1998). In 1999 and 2001, the depression extended from Poinsett County through Cross County into St. Francis County (Joseph, 2000; Schrader, 2004). In 2003, the depression covered most of the western half of Poinsett County (Schrader, 2006). In the 2005 potentiometric-surface map, the depression covers part of western Poinsett County and extends into northwestern Cross County. In the 2007 potentiometric-surface map, the 140-ft contour has expanded to the largest area, extending north to the Poinsett-Craighead County line, further east, and the farthest extent south into Cross County.

Unlike other depressions, the depression in Poinsett and Cross Counties is caused by withdrawals for irrigation, instead of withdrawals for public supply and industrial uses. The Mississippi Embayment Regional Aquifer Study project has identified an area near Poinsett and Cross Counties where the Sparta-Memphis aquifer and the Mississippi River Valley alluvial aquifer (herein referred to as the alluvial aquifer) are hydrologically connected. Borehole geophysical logs show 
that the Jackson Formation, the unit that underlies the alluvial aquifer; the Cockfield Formation of Claiborne Group; and the Cook Mountain Formation of Claiborne Group, the unit that confines the Sparta-Memphis aquifer are absent in this area (Rheannon M. Hart, U.S. Geological Survey, written commun., 2007). Irrigation withdrawals from the alluvial aquifer have resulted in water-level declines in the Sparta-Memphis aquifer (Schrader, 2008).

Five other depressions are shown on the 2007 potentiometric surface. The depression in Columbia County was first shown on the 1996-97 potentiometric-surface map (Joseph, 1998). An initial perception of this depression on the 2007 potentiometric-surface map is that the area has greatly decreased, with water levels rising about $21 \mathrm{ft}$ since 2005 in the well with the deepest measurement. Further investigation revealed that fewer data points were collected in 2007 in this area. The two sites that historically had the deepest water levels were not measured in 2007; therefore, the apparent changes in this depression may be the result of the distribution and number of data points in 2007. The depression in Calhoun County was first shown on the 1999 potentiometric-surface map (Joseph, 2000). The area and depth remained reasonably consistent from 2001 to 2005 (Schrader, 2004, 2006; Schrader and Jones, 2007). This depression has expanded and deepened on the 2007 potentiometric-surface map. The depression in Bradley, Drew, and Ashley Counties was not evident on previous potentiometric-surface maps. The depression shown in eastern Crittenden County is the western edge of the cone of depression in western Tennessee (Schrader, 2008). The depression in Cleveland County was first shown on the 2003 potentiometric-surface map (Schrader, 2006). This depression has deepened from 24 to $18 \mathrm{ft}$ above NGVD of 1929 from 2003 to 2007 . The area enclosed by the $40-\mathrm{ft}$ contour has remained reasonably consistent from 2003 to 2007.

\section{Water-Level Difference from 2003 to 2007}

A water-level difference map (plate 2) was constructed using the difference between water-level measurements made during 2003 and 2007 from 283 wells (appendix 2). The difference in water level was calculated by subtracting the 2007 depth-to-water level from the 2003 depth-to-water level. Negative values indicate a decline and positive values indicate a rise in water level. Rises in the water level are indicated on plate 2 with blue triangles pointing upward; declines in the water level are indicated with red triangles pointing downward. Triangles are scaled to the relative value of the rise or decline. Water-level differences do not necessarily indicate a long-term water-level trend, but are intended to show where water levels have increased or decreased from 2003 to 2007.

The difference in water level between 2003 and 2007 ranged from -49.8 to $60.0 \mathrm{ft}$. The largest measured rise $(60.0$ $\mathrm{ft}$ ) in water level was in Union County. The largest measured decline (-49.8 ft) in water level was in Lincoln County. Areas with a general rise in water levels occur in northern Arkansas
County, central Columbia County, southern Jefferson County, and most of Union County (plate 2). The inset area on plate 2 shows a more detailed view of part of Union County. In the area around west-central Union County (plate 2), water levels in 15 wells rose $20 \mathrm{ft}$ or more, which is an average annual rise of $5 \mathrm{ft}$ or more. The rising water level around west-central Union County coincides with water conservation measures initiated in 1999 and the conversion of large industrial groundwater users to surface water from the Ouachita River beginning in December 2004 (Freiwald and Johnson, 2008). Water levels generally declined throughout most of the SpartaMemphis aquifer.

\section{Long-Term Hydrographs}

Hydrographs from 157 wells were constructed with a minimum of 25 years of water-level measurements. Selected hydrographs are shown in figure 4 with locations indicated on plate 1 . The minimum 25 -year period of record is used to evaluate long-term trends not dominated by variations in climate and localized pumping rates on water levels in a single well. A trend line using linear regression was calculated for the period from 1983 to 2007 to determine the slope in feet per year (ft/yr) for water levels in each well. The slope of the trend line represents the typical annual decline or rise in water level during the 25-year period. A statistical summary of the number of wells, the range of the annual rise or decline in water level for the county, the mean, the median, and the range of the R2 values for each county are listed in table 2 . Negative values denote a decline in water level.

During the period 1983-2007, county mean annual water levels generally declined. The county mean annual water level rose in Calhoun, Columbia, Hot Spring, and Lafayette Counties (table 2). Mean annual declines were between $0.5 \mathrm{ft} /$ yr and $0.0 \mathrm{ft} / \mathrm{yr}$ in Crittenden, Dallas, Grant, Monroe, Ouachita, Phillips, and Woodruff Counties. Mean annual declines were between $1.0 \mathrm{ft} / \mathrm{yr}$ and $0.5 \mathrm{ft} / \mathrm{yr}$ in Craighead, Cross, Desha, Drew, and Union Counties. Mean annual declines were between $1.5 \mathrm{ft} / \mathrm{yr}$ and $1.0 \mathrm{ft} / \mathrm{yr}$ in Arkansas, Bradley, Cleveland, Jefferson, Poinsett, and Prairie Counties. The mean annual decline for Lincoln County was $2.11 \mathrm{ft} / \mathrm{yr}$. The data set for Lincoln County wells was skewed by a single well having an annual decline of $4.38 \mathrm{ft} / \mathrm{yr}$. The median annual decline for Lincoln County was $1.48 \mathrm{ft} / \mathrm{yr}$.

Water levels in the Sparta-Memphis aquifer may change substantially throughout the year. In western Arkansas County, hydrograph B (fig. 4, plate 1) shows a 2-year period of daily water levels. In September 2006, a transducer was installed at this site to collect hourly water levels. These data are transmitted four times a day for display on the USGS water data web site (http://waterdata.usgs.gov). The hydrograph shows about a $60-\mathrm{ft}$ seasonal change in water level for both years shown. The period of the $60-\mathrm{ft}$ decline in water level coincides with the spring-summer irrigation season. 


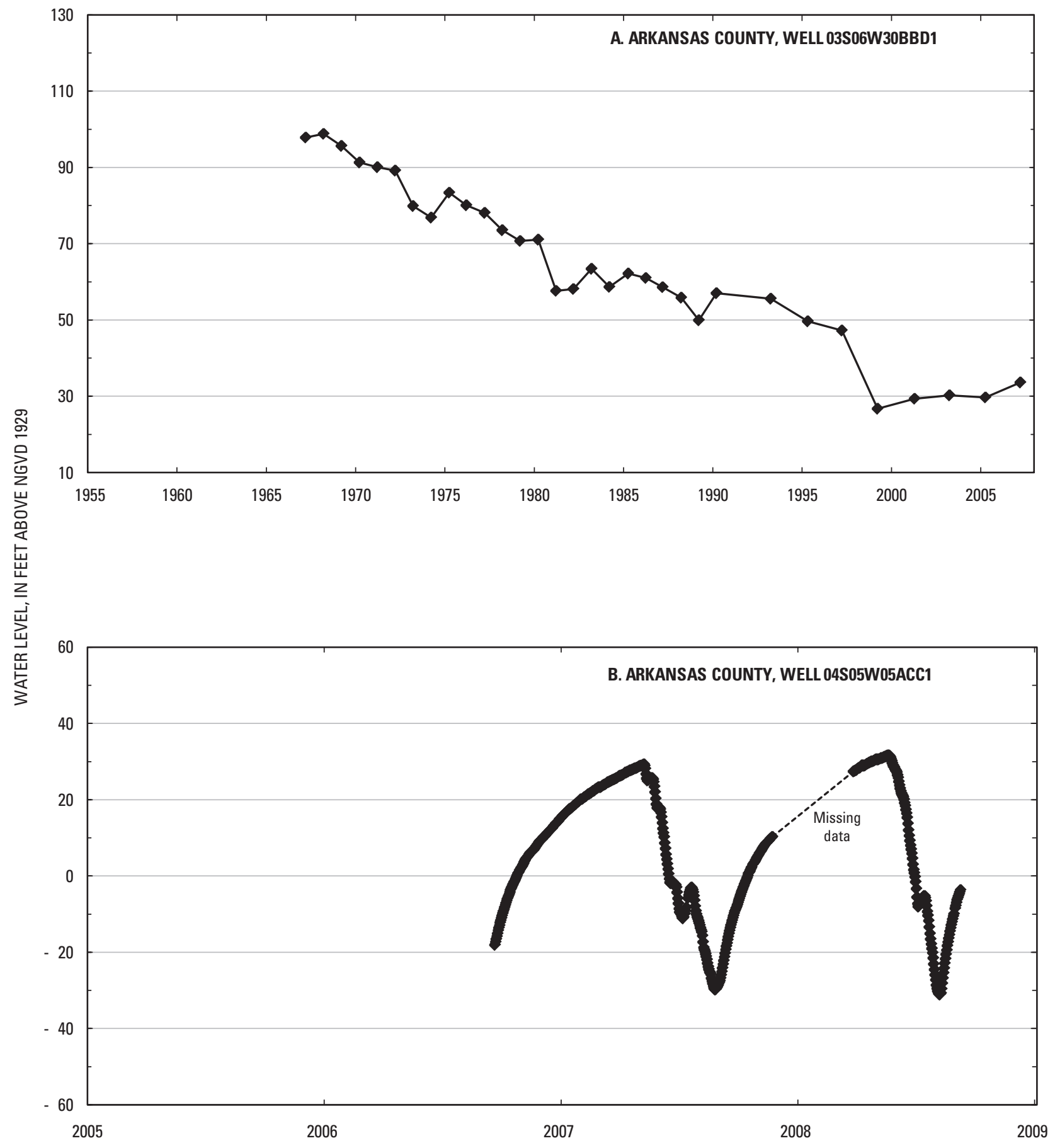

Figure 4. Water-level hydrographs for selected wells completed in the Sparta-Memphis aquifer in Arkansas. Well location listed in appendix 1. 


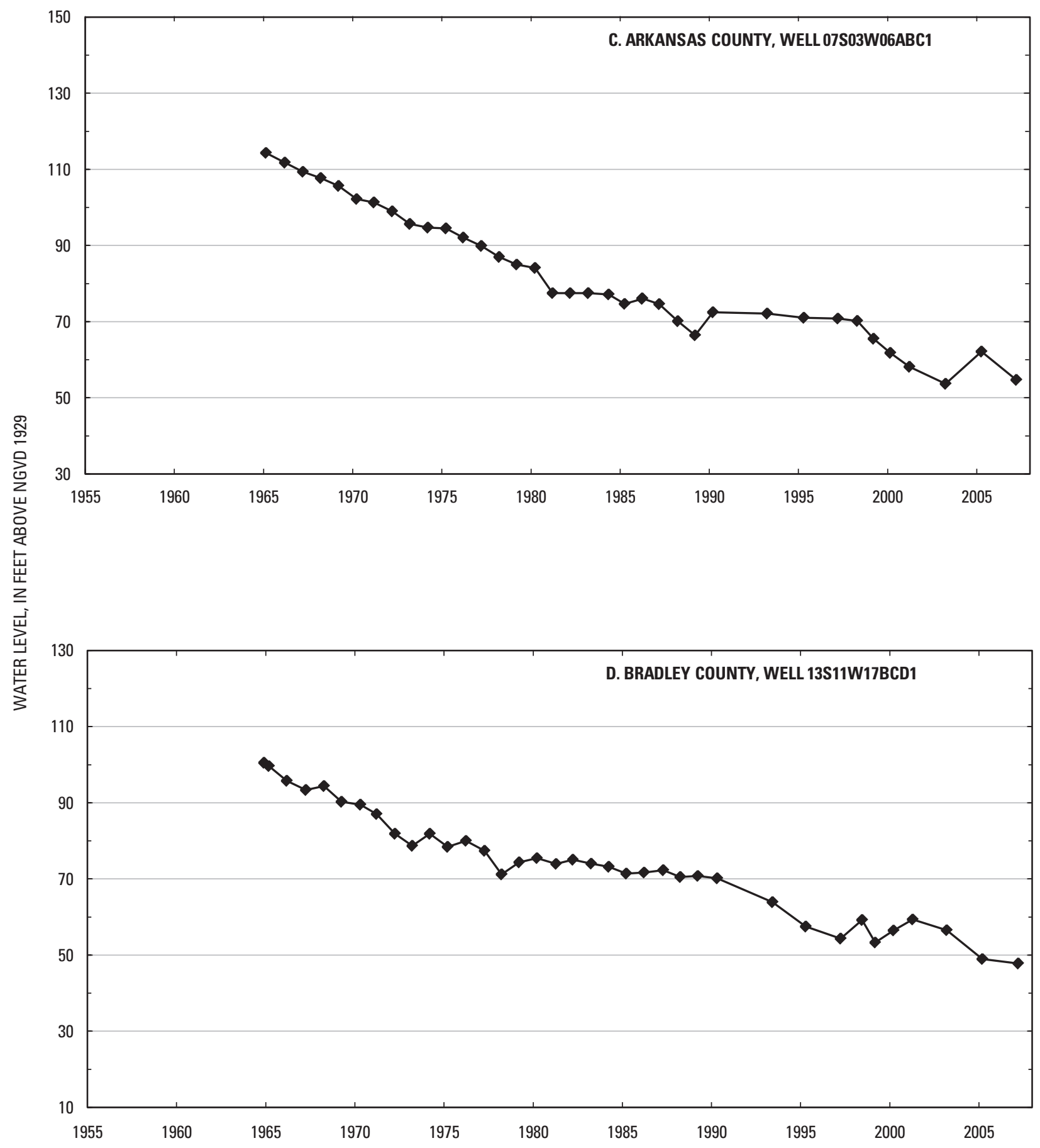

Figure 4. Water-level hydrographs for selected wells completed in the Sparta-Memphis aquifer in Arkansas. Well location listed in appendix 1.-Continued 


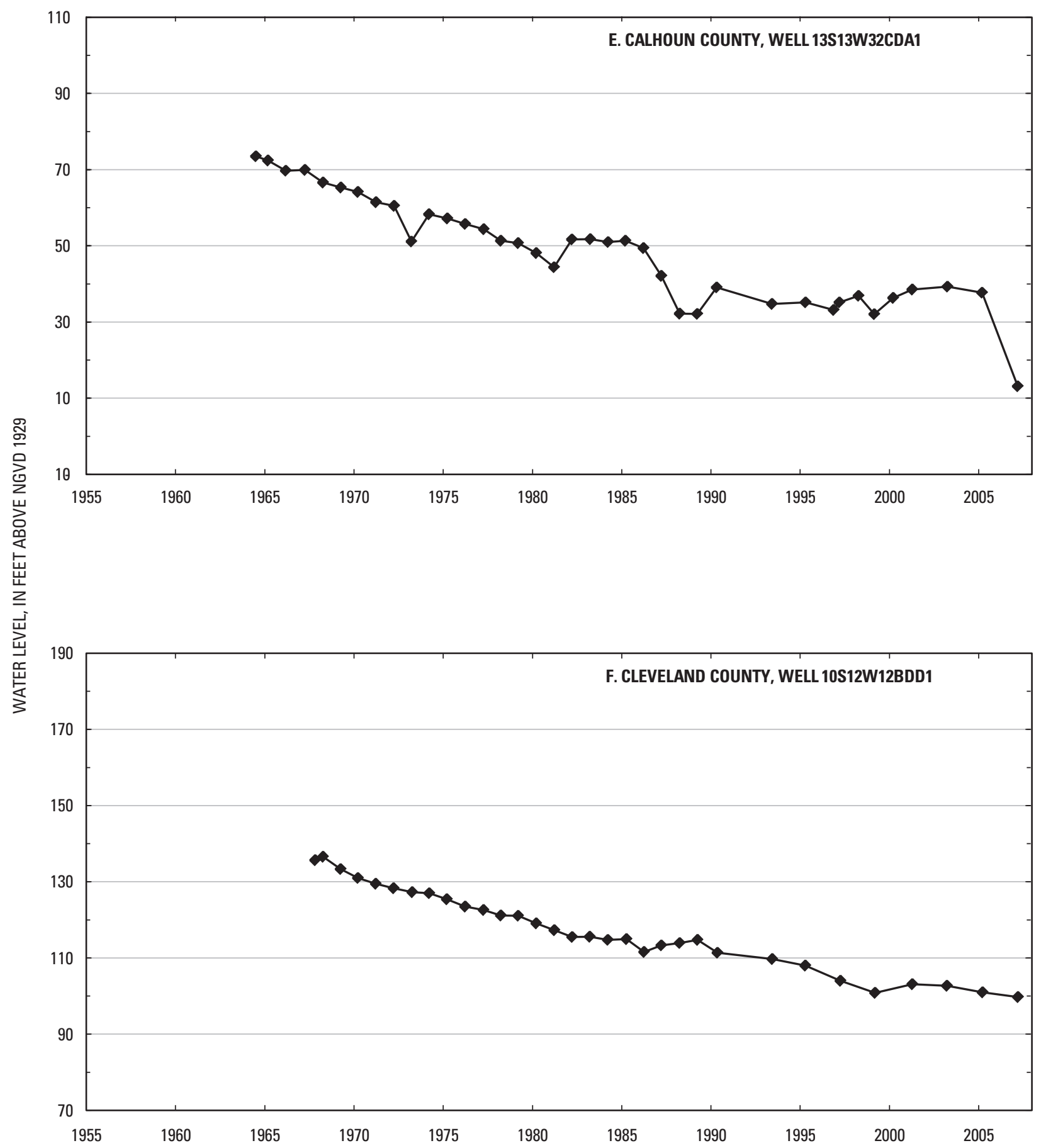

Figure 4. Water-level hydrographs for selected wells completed in the Sparta-Memphis aquifer in Arkansas. Well location listed in appendix 1.-Continued 


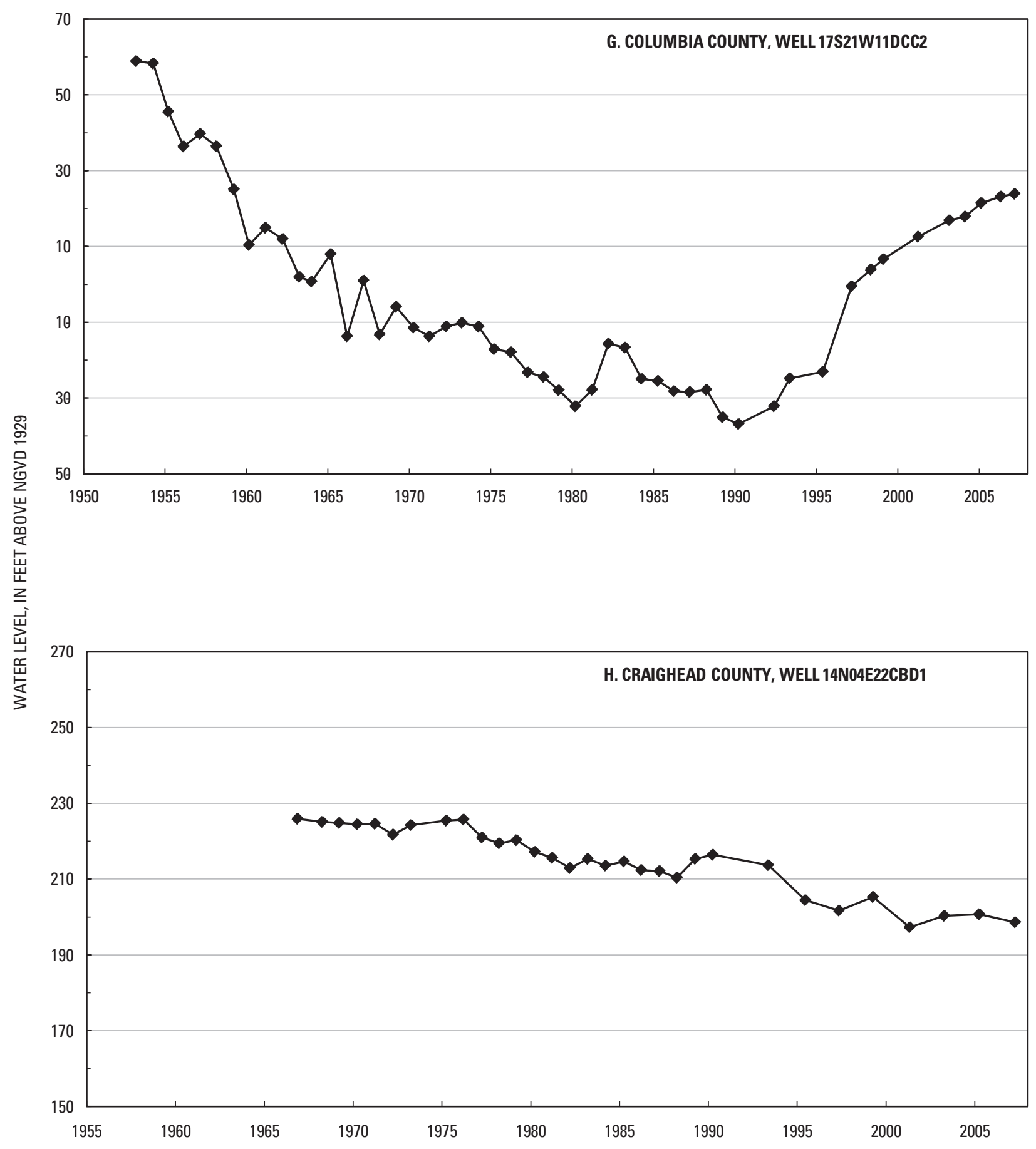

Figure 4. Water-level hydrographs for selected wells completed in the Sparta-Memphis aquifer in Arkansas. Well location listed in appendix 1.-Continued 


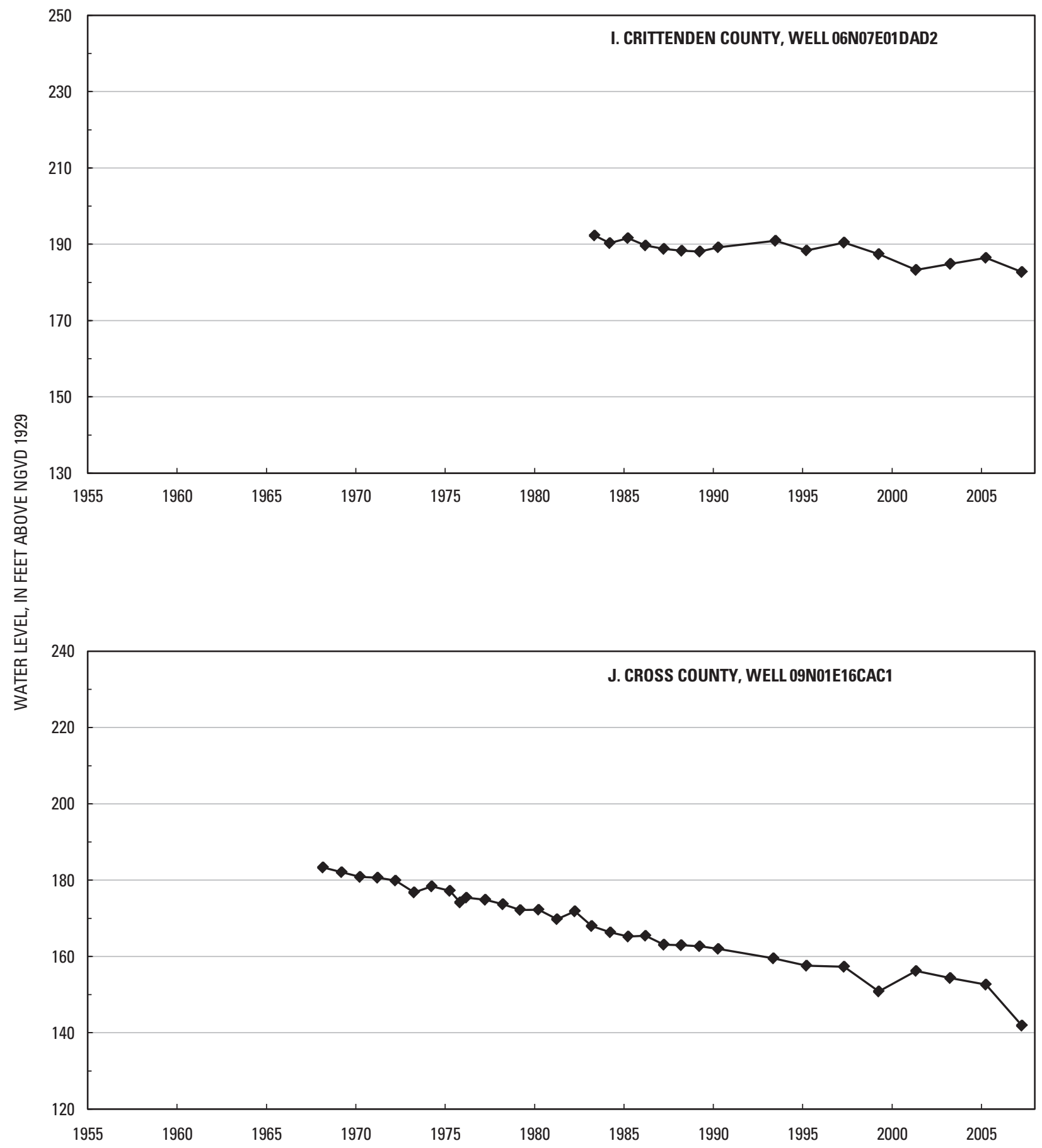

Figure 4. Water-level hydrographs for selected wells completed in the Sparta-Memphis aquifer in Arkansas. Well location listed in appendix 1.-Continued 


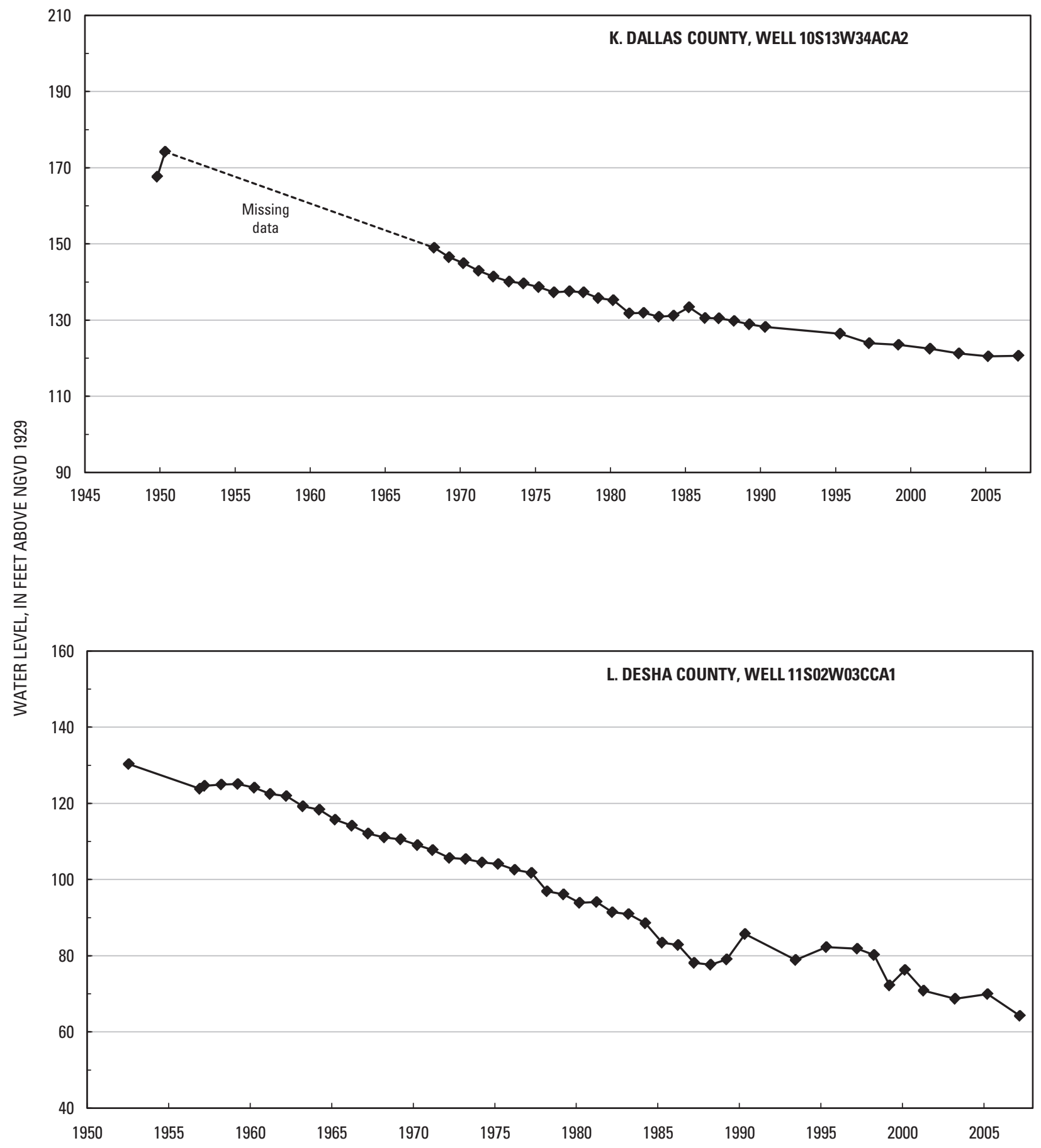

Figure 4. Water-level hydrographs for selected wells completed in the Sparta-Memphis aquifer in Arkansas. Well location listed in appendix 1.-Continued 


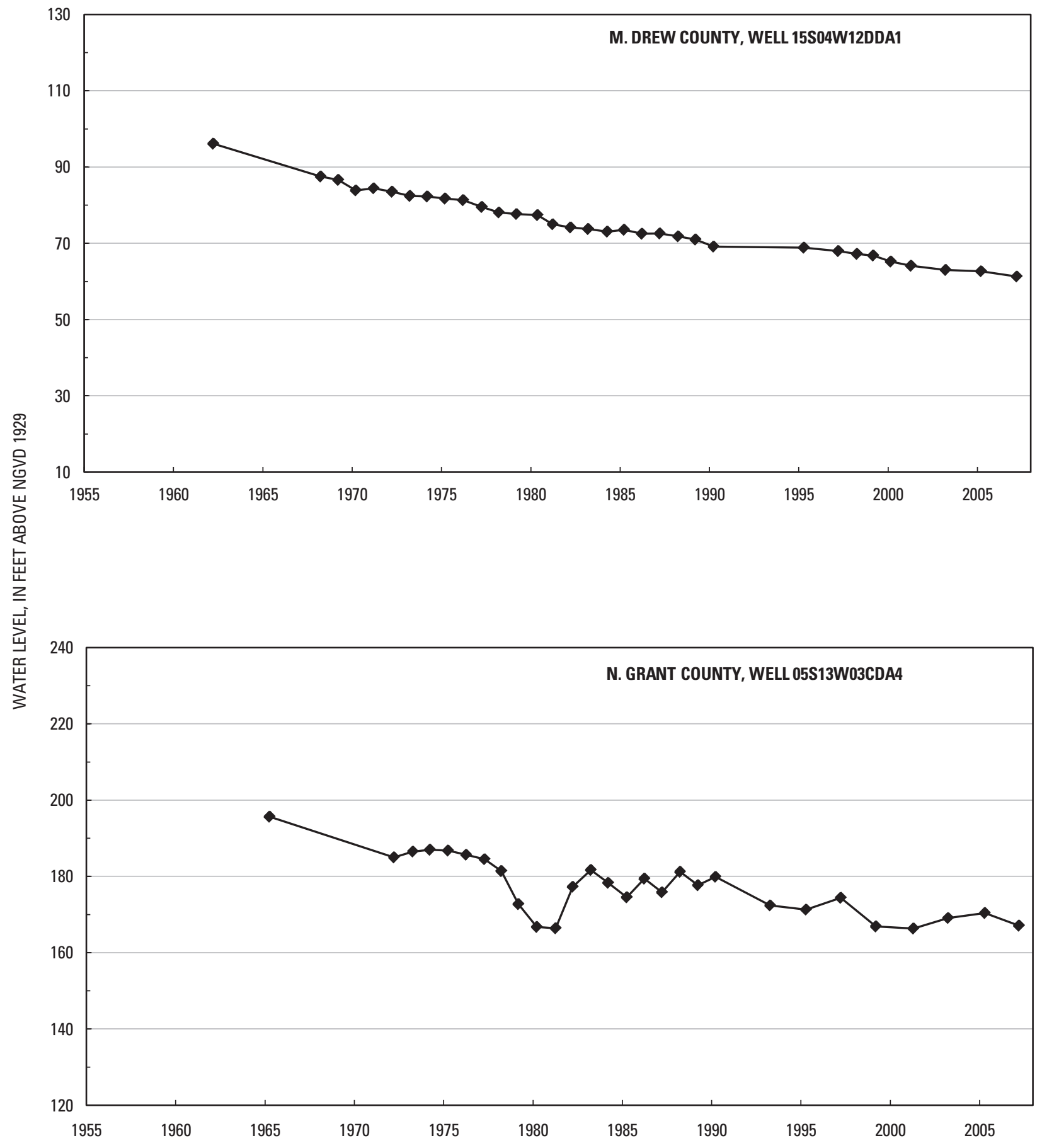

Figure 4. Water-level hydrographs for selected wells completed in the Sparta-Memphis aquifer in Arkansas. Well location listed in appendix 1.-Continued 


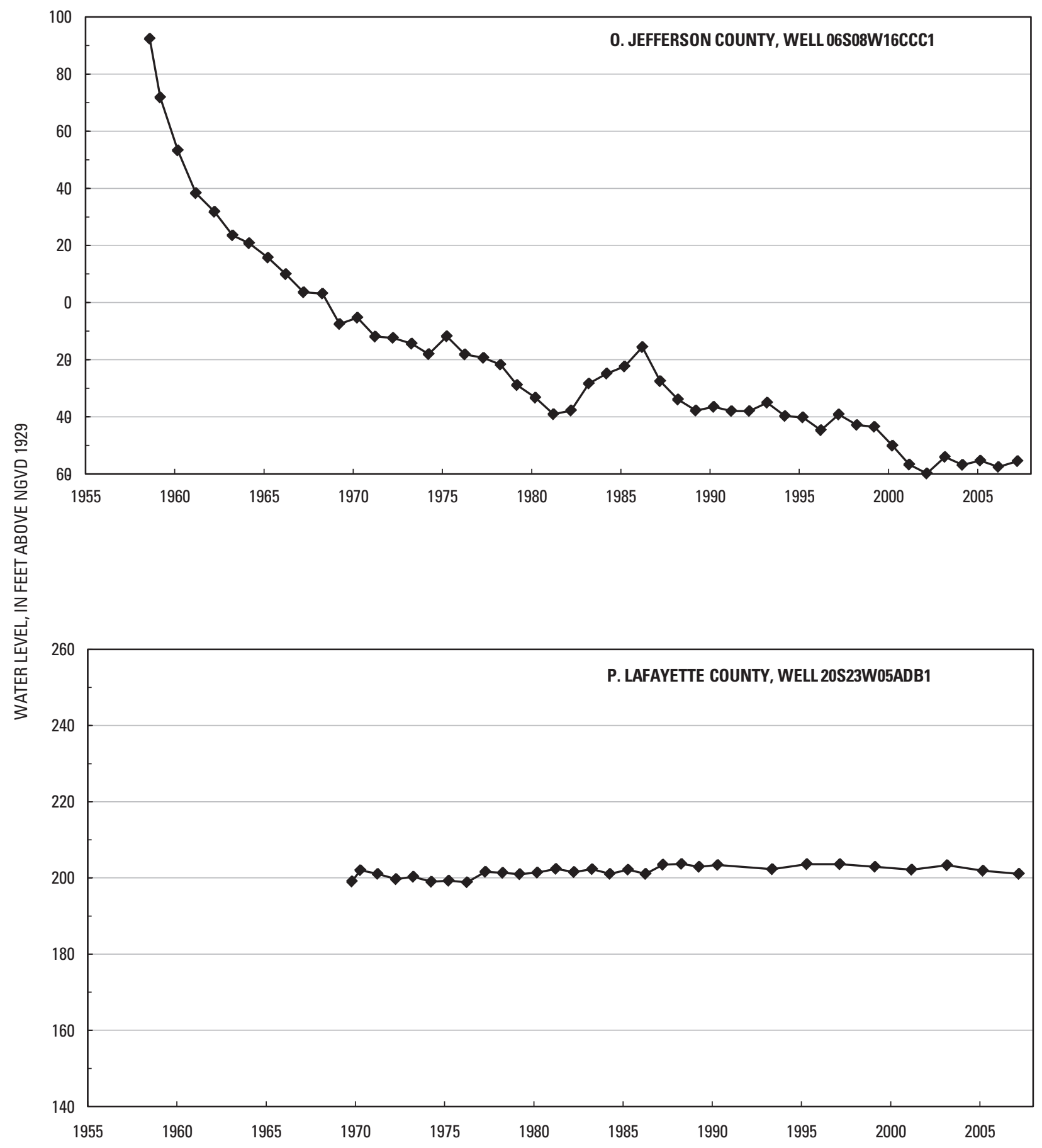

Figure 4. Water-level hydrographs for selected wells completed in the Sparta-Memphis aquifer in Arkansas. Well location listed in appendix 1.-Continued 


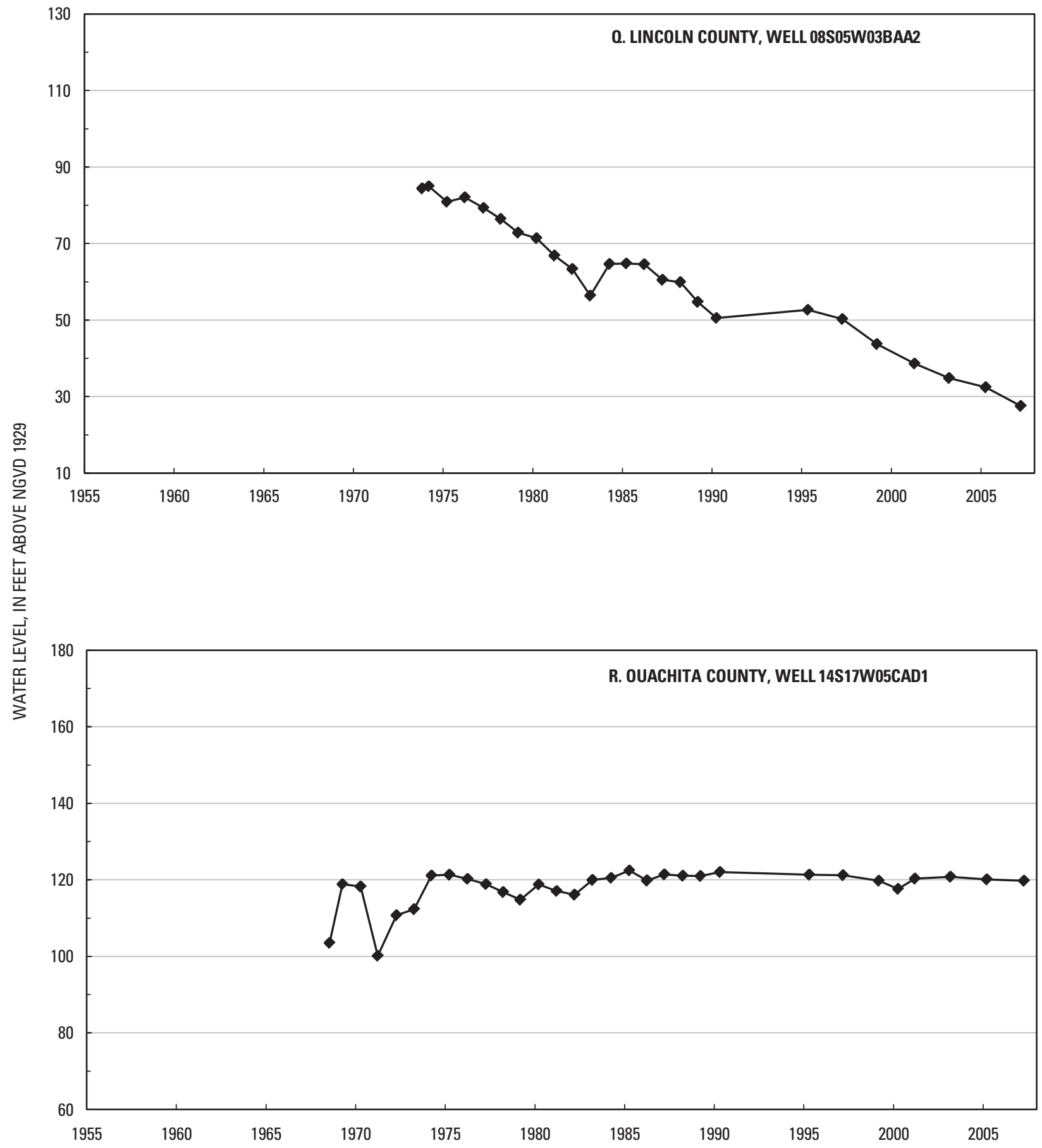

Figure 4. Water-level hydrographs for selected wells completed in the Sparta-Memphis aquifer in Arkansas. Well location listed in appendix 1.-Continued 


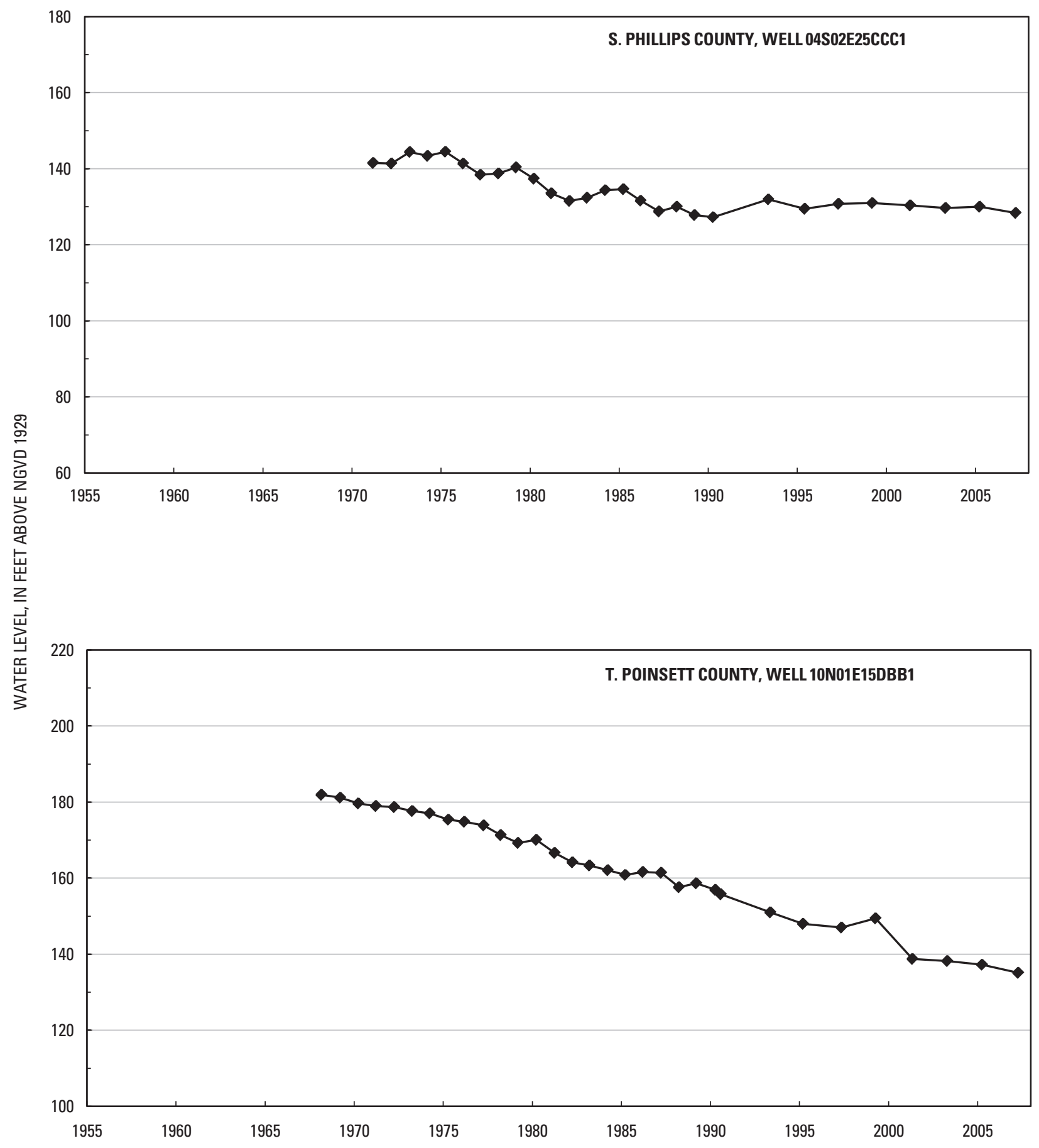

Figure 4. Water-level hydrographs for selected wells completed in the Sparta-Memphis aquifer in Arkansas. Well location listed in appendix 1.-Continued 


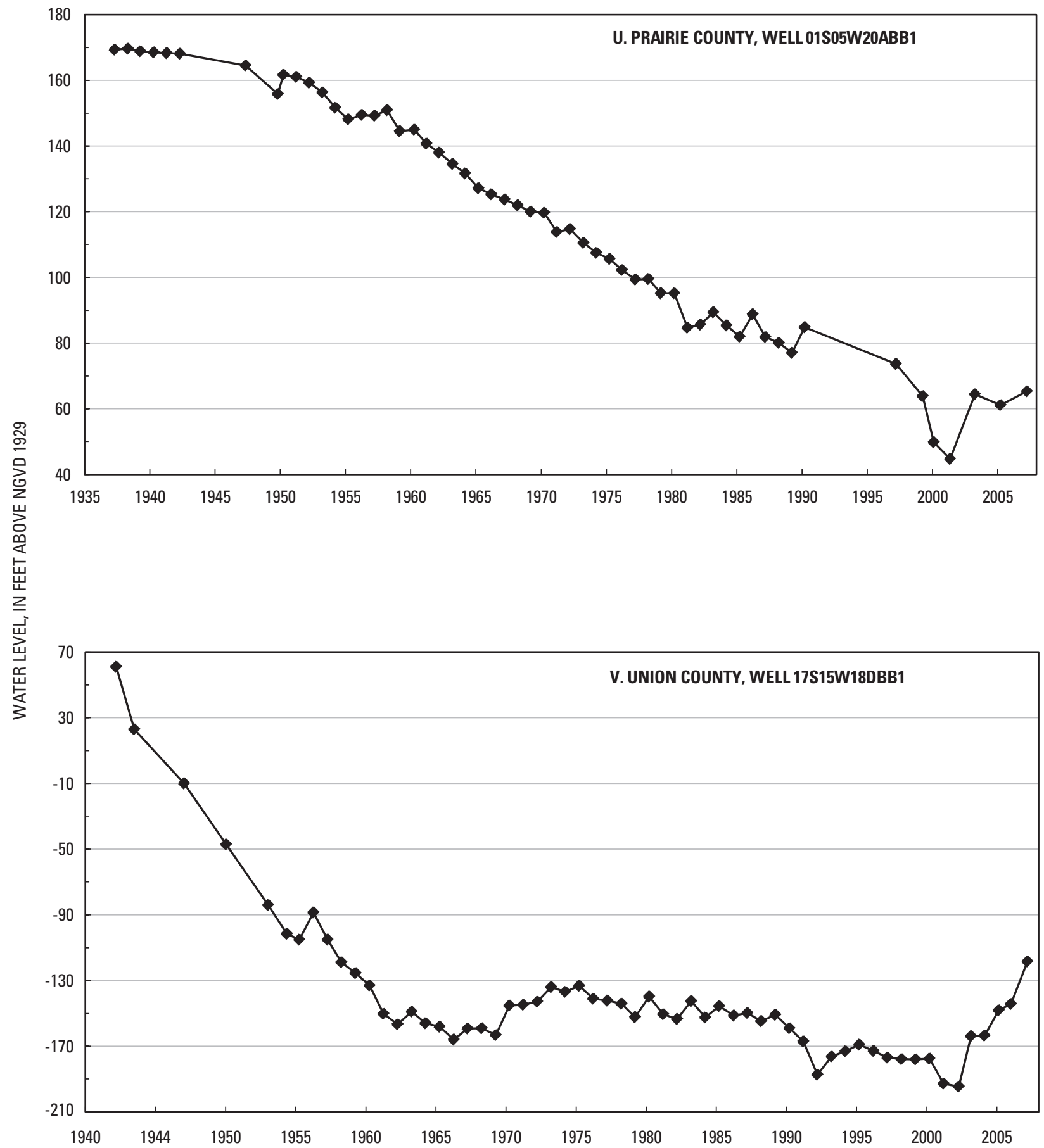

Figure 4. Water-level hydrographs for selected wells completed in the Sparta-Memphis aquifer in Arkansas. Well location listed in appendix 1.-Continued 


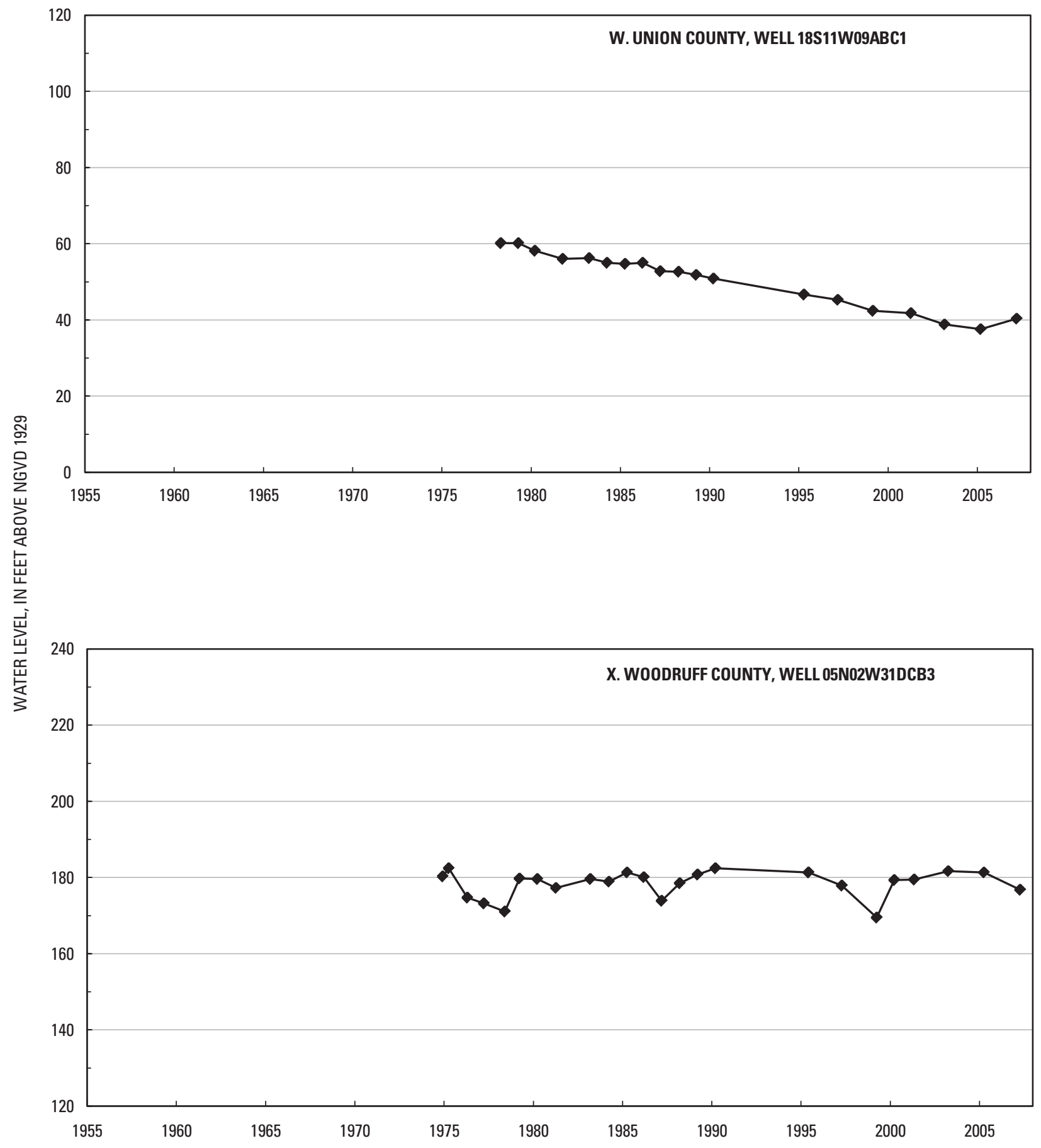

Figure 4. Water-level hydrographs for selected wells completed in the Sparta-Memphis aquifer in Arkansas. Well location listed in appendix 1.-Continued 
Table 2. Statistical summary of annual rise-decline in water level by county for wells in the Sparta-Memphis aquiifer, 1983-2007.

[Annual rise or decline in water level for each well is calculated using linear regression; negative value indicates decline; positive value indicates rise]

\begin{tabular}{|c|c|c|c|c|c|}
\hline County & $\begin{array}{l}\text { Number } \\
\text { of wells }\end{array}$ & $\begin{array}{l}\text { Range of annual } \\
\text { rise-decline in } \\
\text { water level } \\
\text { (feet/year) }\end{array}$ & $\begin{array}{l}\text { Mean annual } \\
\text { rise-decline in } \\
\text { water level } \\
\text { (feet/year) }\end{array}$ & $\begin{array}{l}\text { Median annual } \\
\text { rise-decline in } \\
\text { water level } \\
\text { (feet/year) }\end{array}$ & $\begin{array}{l}\text { Range of } R^{2} \text { values } \\
\text { for trend line }\end{array}$ \\
\hline Arkansas & 23 & -2.25 to 0.18 & -1.15 & -1.28 & 0.50 to 0.88 \\
\hline Bradley & 4 & -1.61 to -0.77 & -1.26 & -1.33 & 0.38 to 0.97 \\
\hline Calhoun & 2 & -0.84 to -0.80 & 0.82 & 0.82 & 0.48 to 0.77 \\
\hline Cleveland & 3 & -1.79 to -0.73 & -1.11 & -0.80 & 0.90 to 0.92 \\
\hline Columbia & 8 & -0.58 to 2.52 & 0.24 & -0.18 & 0.11 to 0.80 \\
\hline Craighead & 3 & -0.80 to -0.03 & -0.53 & -0.77 & 0.73 to 0.81 \\
\hline Crittenden & 4 & -0.29 to 0.07 & -0.16 & -0.20 & 0.11 to 0.66 \\
\hline Cross & 4 & -1.28 to -0.69 & -1.00 & -1.00 & 0.68 to 0.94 \\
\hline Dallas & 7 & -0.51 to 0.15 & -0.23 & -0.22 & 0.14 to 0.97 \\
\hline Desha & 5 & -1.61 to -0.69 & -0.91 & -0.73 & 0.37 to 0.92 \\
\hline Drew & 5 & -0.91 to -0.37 & -0.62 & -0.51 & 0.83 to 0.98 \\
\hline Grant & 6 & -1.46 to -0.07 & -0.50 & -0.38 & 0.18 to 0.93 \\
\hline Hot Spring & 1 & 0.15 & 0.15 & 0.15 & 0.41 \\
\hline Jefferson & 14 & -2.15 to -0.47 & -1.27 & -1.26 & 0.37 to 0.89 \\
\hline Lafayette & 2 & 0.00 to 0.07 & 0.04 & 0.04 & 0.04 \\
\hline Lincoln & 6 & -4.38 to -1.13 & -2.11 & -1.48 & 0.42 to 0.94 \\
\hline Monroe & 3 & -0.95 to 0.80 & -0.11 & -0.18 & 0.20 to 0.87 \\
\hline Ouachita & 9 & -1.06 to 0.84 & -0.06 & -0.01 & 0.12 to 0.92 \\
\hline Phillips & 6 & -0.73 to 0.47 & -0.29 & -0.44 & 0.18 to 0.95 \\
\hline Poinsett & 2 & -1.24 to -0.88 & -1.02 & -1.02 & 0.68 to 0.95 \\
\hline Prairie & 9 & -1.61 to -0.29 & -1.23 & -1.31 & 0.11 to 0.97 \\
\hline Union & 30 & -1.57 to 2.52 & -0.66 & -0.84 & 0.12 to 0.97 \\
\hline Woodruff & 1 & -0.04 & -0.04 & -0.04 & 0.71 \\
\hline
\end{tabular}




\section{Water-Quality Conditions}

Water samples were collected in the summer of 2007 from 129 Sparta-Memphis wells and measured onsite for specific conductance and temperature. Samples were collected from 102 wells for dissolved chloride analysis at the USGS National Water Quality Laboratory (appendix 3).

Specific-conductance data indicate regionally diverse zones of mineralized water across the study area (plate 3 ). Specific conductance ranged from 35 microsiemens per centimeter at 25 degrees Celsius $(\mu \mathrm{S} / \mathrm{cm})$ in Ouachita County to $1,280 \mu \mathrm{S} / \mathrm{cm}$ at two wells in Monroe County. The mean specific conductance was $398 \mu \mathrm{S} / \mathrm{cm}$ and the median specific conductance was $334 \mu \mathrm{S} / \mathrm{cm}$. Dissolved chloride concentrations ranged from 1.2 milligrams per liter $(\mathrm{mg} / \mathrm{L})$ in Lincoln County to $308 \mathrm{mg} / \mathrm{L}$ in Monroe County. The mean chloride concentration was $28.6 \mathrm{mg} / \mathrm{L}$ and the median chloride concentration was $8.7 \mathrm{mg} / \mathrm{L}$. Along the western border of the SpartaMemphis aquifer near the outcrop area, specific conductance is low-generally less than $200 \mu \mathrm{S} / \mathrm{cm}$. Specific conductance generally increases to the east and south. Recharge occurs within the outcrop, subcrop, and from infiltration of overlying or underlying formations into the Sparta-Memphis aquifer. As water flows through the Sparta-Memphis aquifer, chemical interactions (mineralization) occur with the sediment of the aquifer. The chemical interactions may cause changes in water quality. The residence time of the water within the aquifer will increase along the flow direction from the recharge area causing increased specific conductance and chloride concentrations. This gradual increase of specific conductance continues south to the Louisiana State line.

Although there is a regional increase in specific conductance to the east and south, anomalous increases occur in some parts of the study area. Relatively large specific conductance values (greater than $700 \mu \mathrm{S} / \mathrm{cm}$ and less than $1,300 \mu \mathrm{S} / \mathrm{cm}$ ) occur in samples from wells in Arkansas, Ashley, Monroe, Phillips, and Union Counties. Morris and Bush (1986) and Broom and others (1984) cited upward leakage of saltwater from the Nacatoch aquifer of Cretaceous age into the Sparta aquifer through a fault or abandoned oil and gas wells as possible explanations for these anomalies. Large specific conductance values occur near the water-level cone of depression (plate 1) in Union County and increase eastward toward Ashley County. This increase in specific conductance may be because of leakage of water with greater conductance from an underlying aquifer. A previous study documented several specific-conductance values greater than 2,000 $\square \mathrm{S} / \mathrm{cm}$ for groundwater from the Sparta aquifer in Union County (Broom and others, 1984).

\section{Summary}

The U.S. Geological Survey in cooperation with the Arkansas Natural Resources Commission and the Arkansas
Geological Survey has monitored water levels since the 1920 's. Groundwater withdrawals have increased while water levels have declined since monitoring was initiated. During the spring of 2007, 309 water levels were measured in wells completed in the Sparta-Memphis aquifer. During the summer of 2007, 129 water-quality samples were collected and measured for temperature and specific conductance and 102 were collected and analyzed for chloride from wells completed in the Sparta-Memphis aquifer.

Water use in the Sparta-Memphis aquifer in Arkansas generally increased from 1965 to 2000. In 2000, water use in the Sparta-Memphis aquifer was about $287 \mathrm{Mgal} / \mathrm{d}$, an increase of about 156 percent from 1965. In 2005, water use in the Sparta-Memphis aquifer declined to about $170 \mathrm{Mgal} / \mathrm{d}$.

The Sparta Sand is composed of a sequence of alternating sand and clay beds between the massive clays of the overlying Cook Mountain Formation of Claiborne Group and the underlying Cane River Formation of Claiborne Group confining units. The Sparta Sand is in the southern part of the study area (south of about 35 degrees latitude). The Memphis Sand is in the northern part of the study area (north of about 35 degrees latitude). The Memphis Sand is underlain by a thick layer of clay in the upper part of the Wilcox Group.

The regional direction of groundwater flow in the SpartaMemphis aquifer is generally to the south-southeast in the northern half of Arkansas and to the east and south in the southern half of Arkansas, away from the outcrop area except where affected by large groundwater withdrawals. The highest water-level altitude measured in the Sparta-Memphis aquifer was $326 \mathrm{ft}$ above NGVD of 1929 in the outcrop at the western boundary of the study area; the lowest water-level altitude was $161 \mathrm{ft}$ below NGVD of 1929 in Union County.

Eight cones of depression (generally represented by closed contours) are located in the study area. Two large cones of depression, centered in Jefferson and Union Counties, are the result of large withdrawals for industrial and public supplies. The depression centered in Jefferson County has deepened and expanded in recent years into Arkansas and Prairie Counties are the result of large withdrawals for irrigation and public supply. The area enclosed within the $40-\mathrm{ft}$ contour on the 2007 potentiometric-surface map has expanded when compared with the 2005 potentiometric-surface map. In 2003, the depression in Union County was elongated east and west and beginning to coalesce with the depression in Columbia County. The deepest measurement during 2007 in the center of the depression in Union County has risen $38 \mathrm{ft}$ since 2003. The area enclosed by the deepest contour, $160 \mathrm{ft}$ below NGVD of 1929 , on the 2007 potentiometric-surface map is less than 10 percent of the area on the 2005 potentiometric-surface map. A broad depression in western Poinsett and Cross Counties was first shown in the 1995 potentiometric-surface map caused by withdrawals for irrigation extending north to the PoinsettCraighead County line, and south into Cross County.

A water-level difference map was constructed using the difference between water-level measurements made during 2003 and 2007 from 283 wells. The difference in water level 
between 2003 and 2007 ranged from -49.8 to $60.0 \mathrm{ft}$. Areas with a general rise in water levels are shown in northern Arkansas, central Columbia, southern Jefferson, and most of Union Counties. In the area around west-central Union County, water levels rose as much as $60.0 \mathrm{ft}$, with water levels in 15 wells rising $20 \mathrm{ft}$ or more, which is an average annual rise of $5 \mathrm{ft}$ or more. Water levels generally declined throughout most of the rest of Arkansas.

Hydrographs from 157 wells were constructed with a minimum of 25 years of water-level measurements. During the period 1983-2007, the county mean annual water level rose in Calhoun, Columbia, Hot Spring, and Lafayette Counties. Mean annual declines between $0.0 \mathrm{ft} / \mathrm{yr}$ and $2.1 \mathrm{ft} / \mathrm{yr}$ occurred in all the other counties. In western Arkansas County, a hydrograph shows a 60 -ft seasonal change in water level for both years shown. The period of the $60-\mathrm{ft}$ decline in water level coincides with the spring-summer irrigation season.

Specific-conductance data indicate regionally diverse zones of mineralized water within the aquifers across the study area. Specific conductance ranged from $35 \mu \mathrm{S} / \mathrm{cm}$ in Ouachita County to $1,280 \mu \mathrm{S} / \mathrm{cm}$ at two wells in Monroe County. The mean specific conductance was $398 \mu \mathrm{S} / \mathrm{cm}$ and the median specific conductance was $334 \mu \mathrm{S} / \mathrm{cm}$. Dissolved chloride concentrations ranged from $1.2 \mathrm{mg} / \mathrm{L}$ in Lincoln County to $308 \mathrm{mg} / \mathrm{L}$ in Monroe County. The mean dissolved chloride concentration was $28.6 \mathrm{mg} / \mathrm{L}$ and the median dissolved chloride concentration was $8.7 \mathrm{mg} / \mathrm{L} A$ Although there is a regional increase in specific conductance to the east and south, anomalous increases occur in some parts of the study area. Relatively large specific conductance values (greater than $700 \mu \mathrm{S} / \mathrm{cm}$ and less than $1,300 \mu \mathrm{S} / \mathrm{cm}$ ) occur in samples from wells in Arkansas, Ashley, Monroe, Phillips, and Union Counties.

\section{Selected References}

Broom, M.E., Kraemer, T.F., and Bush, W.V., 1984, A reconnaissance study of saltwater contamination in the El Dorado aquifer, Union County, Arkansas: U.S. Geological Survey Water-Resources Investigations Report 84-4012, 47 p.

Edds, Joe, and Fitzpatrick, D.J., 1985, Maps showing altitude of the potentiometric surface and changes in water levels of the Sparta Sand and Memphis Sand aquifers in eastern Arkansas, spring 1984: U.S. Geological Survey WaterResources Investigations Report 85-4223, 1 sheet.

Edds, Joe, and Fitzpatrick, D.J., 1989, Altitude of the potentiometric surface and changes in water levels in the SpartaMemphis aquifer in eastern and southern Arkansas, spring 1986: U.S. Geological Survey Water-Resources Investigations Report 88-4042, 1 sheet.

Fenneman, N.M., 1938, Physiography of eastern United States: New York, McGraw-Hill Book Co., Inc., 689 p.
Fishman, M.J., and Friedman, L.C., 1989, Methods for determination of inorganic substances in water and fluvial sediments: U.S. Geological Survey Techniques of WaterResources Investigations, book 5, chap. A1, 545 p.

Freiwald, D.A., and Johnson, S.F., 2008, Monitoring of Sparta aquifer recovery in southern Arkansas and Northern Louisiana, 2003-07: U.S. Geological Survey Fact Sheet 2007$3102,4 \mathrm{p}$.

Halberg, H.N., 1972, Use of water in Arkansas, 1970: Arkansas Geological Commission, Water Resources Summary Number 7, $17 \mathrm{p}$.

Halberg, H.N., 1977, Use of water in Arkansas, 1975: Arkansas Geological Commission, Water Resources Summary Number 9, 28 p.

Halberg, H.N., and Stephens, J.W., 1966, Use of water in Arkansas, 1965: Arkansas Geological Commission, Water Resources Summary Number 5, 12 p.

Hart, R. M., Clark, B. R., and Bolyard, S. E., 2008, Digital surfaces and thicknesses of selected hydrogeologic units within the Mississippi Embayment regional aquifer study (MERAS): U.S. Geological Survey Scientific Investigations Report 2008-5098, accessed March 9, 2009, at http://pubs.usgs.gov/sir/2008/5098/

Helsel, D.R., and Hirsch, R.M., 1992, Statistical methods in water resources: New York, N.Y., Elsevier Science Publishing Co., 522 p.

Holland, T.W., 1987, Use of water in Arkansas, 1985: Arkansas Geological Commission Water Resources Summary Number 14, $30 \mathrm{p}$.

Holland, T.W., 1993, Use of water in Arkansas, 1990: U.S. Geological Survey Open-File Report 93-48, pamphlet.

Holland, T.W., 1999, Water use in Arkansas, 1995: U.S. Geological Survey Open-File Report 99-188, 1 sheet.

Holland, T.W., 2004, Estimated water use in Arkansas, 2000: U.S. Geological Survey Scientific Investigations Report 2004-5230, $31 \mathrm{p}$.

Holland, T.W., 2007, Water use in Arkansas, 2005: U.S. Geological Survey Scientific Investigations Report 2007-5241, $31 \mathrm{p}$.

Holland, T.W., and Ludwig, A.H., 1981, Use of water in Arkansas: Arkansas Geological Commission, Water Resources Summary Number 14, 30 p.

Hosman, R.L., 1982, Outcropping Tertiary units in southern Arkansas: U.S. Geological Survey Miscellaneous Investigations Series I-1405, 1 sheet. 
Hosman, R.L., Long, A.T., Lambert, T.W., and others, 1968, Tertiary aquifers in the Mississippi Embayment: U.S. Geological Survey Professional Paper 448-D, 29 p.

Hosman, R.L., and Weiss, J.S., 1991, Geohydrologic units of the Mississippi Embayment and Texas Coastal Uplands aquifer systems, South-Central United States: U.S. Geological Survey Professional Paper 1416-B, 19 p.

Joseph, R.L., 1998, Potentiometric surface of the Sparta aquifer in eastern and south-central Arkansas and northcentral Louisiana, and the Memphis aquifer in east-central Arkansas, October 1996-July 1997: U.S. Geological Survey Water-Resources Investigations Report 97-4282, 19 p.

Joseph, R.L., 2000, Status of water levels and selected waterquality conditions in the Sparta and Memphis aquifers in eastern and south-central Arkansas, 1999: U.S. Geological Survey Water-Resources Investigations Report 00-4009, 34 p.

Morris, E.E., and Bush, W.V., 1986, Extent and source of saltwater intrusion into the alluvial aquifer near Brinkley, Arkansas, 1984: U.S. Geological Survey Water-Resources Investigations Report 85-4322, 123 p.

Payne, J.N., 1968, Hydrologic significance of the lithofacies of the Sparta Sand in Arkansas, Louisiana, Mississippi, and Texas: U.S. Geological Survey Professional Paper 569-A, $17 \mathrm{p}$.

Petersen, J.C., Broom, M.E., and Bush, W.V., 1985, Geohydrologic units of the Gulf Coastal Plain in Arkansas: U.S. Geological Survey Water-Resources Investigations Report 85-4116, 20 p.
Schrader, T.P., 2004, Status of water levels and selected water-quality conditions in the Sparta-Memphis aquifer in Arkansas and the Sparta aquifer in Louisiana, spring-summer 2001: U.S. Geological Survey Scientific Investigations Report 2004-5055, 52 p.

Schrader, T.P., 2006, Status of water levels and selected water-quality conditions in the Sparta-Memphis aquifer in Arkansas, spring-summer, 2003: U.S. Geological Survey Scientific Investigations Report 2006-5021, 43 p.

Schrader, T.P., 2008, Potentiomentric surface in the SpartaMemphis aquifer of the Mississippi Embayment, spring 2007: U.S. Geological Survey Scientific Investigations Map 3014, 1 plate.

Schrader, T.P., and Jones, J.S., 2007, Status of water levels and selected water-quality conditions in the Sparta-Memphis aquifer in Arkansas and the status of water levels in the Sparta aquifer in Louisiana, spring 2005: U.S. Geological Survey Scientific Investigations Report 2007-5029, 66 p.

Snider, J.L., Calandro, A.J., and Shampine, W.J., 1972, Water resources of Union Parish, Louisiana: Department of Conservation, Louisiana Geological Survey, and Louisiana Department of Public Works Water Resources Bulletin No. $17,68 \mathrm{p}$.

Stanton, G.P., 1997, Potentiometric surface and specific conductance of the Sparta and Memphis aquifers in eastern and south-central Arkansas, 1995: U.S. Geological Survey Water-Resources Investigations Report 97-4119, 16 p.

U.S. Geological Survey, variously dated, National field manual for the collection of water-quality data: U.S. Geological Survey Techniques of Water-Resources Investigations, book 9, chaps. A1-A9, available online at http://pubs.water.usgs. gov/twri9A. 
APPENDIXES 1-3 
Appendix 1. Water-level data collected during spring 2007 from wells completed in the Sparta-Memphis aquifer in Arkansas.

[NGVD of 1929, National Geodetic Vertical Datum; Horizontal datum is North American Datum of 1983]

\begin{tabular}{|c|c|c|c|c|c|c|}
\hline Station name & $\begin{array}{l}\text { Latitude } \\
\text { (degrees, } \\
\text { minutes, } \\
\text { seconds) }\end{array}$ & $\begin{array}{c}\text { Longitude } \\
\text { (degrees, } \\
\text { minutes, } \\
\text { seconds) }\end{array}$ & $\begin{array}{l}\text { Water-level } \\
\text { altitude } \\
\text { (feet above } \\
\text { NGVD of 1929) }\end{array}$ & $\begin{array}{l}\text { Depth to water } \\
\text { (feet below } \\
\text { land surface) }\end{array}$ & $\begin{array}{c}\text { Land-surface } \\
\text { datum } \\
\text { (feet above } \\
\text { NGVD of 1929) }\end{array}$ & $\begin{array}{c}\text { Date of } \\
\text { measurement }\end{array}$ \\
\hline \multicolumn{7}{|c|}{ Arkansas County } \\
\hline 02S04W06CDB1 & 343312 & 912849 & 53 & 159.24 & 212 & 03/29/07 \\
\hline 02S04W23DAA1 & 343044 & 912355 & 63 & 144.91 & 208 & 03/29/07 \\
\hline 02S04W33BBB1 & 342922 & 912703 & 36 & 168.78 & 205 & $03 / 29 / 07$ \\
\hline 02S05W16CBB1 & 343144 & 913319 & 40 & 172.95 & 213 & 03/29/07 \\
\hline 02S05W27BBB1 & 343028 & 913230 & 37 & 178.79 & 216 & $03 / 29 / 07$ \\
\hline 02S05W34BDA1 & 342925 & 913148 & 36 & 180.13 & 216 & 03/29/07 \\
\hline 02S05W35AAB 1 & 342930 & 913035 & 41 & 174.89 & 216 & 03/29/07 \\
\hline 03S04W02CCB1 & 342748 & 912458 & 49 & 153.40 & 202 & 03/29/07 \\
\hline 03S04W26CDA1 & 342421 & 912438 & 55 & 147.52 & 203 & 03/27/07 \\
\hline 03S05W02AAB 1 & 342842 & 913034 & 37 & 173.32 & 210 & 03/29/07 \\
\hline 03S05W13BDC1 & 342631 & 913005 & 27 & 183.01 & 210 & 03/28/07 \\
\hline 03S05W15CBB1 & 342633 & 913229 & 27 & 179.22 & 206 & 03/28/07 \\
\hline 03S05W28DAB 1 & 342447 & 913240 & 31 & 172.86 & 204 & 03/28/07 \\
\hline 03S06W30BBD1 & 342516 & 914216 & 34 & 157.40 & 191 & 03/28/07 \\
\hline 04S01W04CBD1 & 342225 & 910808 & 83 & 113.42 & 196 & 03/27/07 \\
\hline 04S01W28BAA1 & 341927 & 910748 & 83 & 106.52 & 190 & 03/27/07 \\
\hline 04S04W11BCC1 & 342157 & 912502 & 43 & 155.10 & 198 & 03/27/07 \\
\hline 04S04W19CBB1 & 342004 & 912929 & 31 & 163.58 & 195 & 03/28/07 \\
\hline 04S04W22DAA1 & 342007 & 912515 & 36 & 159.48 & 195 & 03/27/07 \\
\hline 04S05W01BAA1 & 342322 & 912956 & 39 & 156.85 & 196 & 03/28/07 \\
\hline 04S05W05ACC1 & 342303 & 913413 & 27 & 159.40 & 186 & 03/26/07 \\
\hline 04S05W15AAA1 & 342132 & 913133 & 33 & 167.55 & 201 & $03 / 28 / 07$ \\
\hline 04S05W36DCC1 & 341752 & 913004 & 30 & 166.15 & 196 & $03 / 26 / 07$ \\
\hline 05S01W17BAA1 & 341551 & 910745 & 83 & 93.46 & 176 & 03/27/07 \\
\hline 05S03W04ADB1 & 341734 & 912007 & 48 & 140.31 & 188 & 03/27/07 \\
\hline 05S04W26ACA1 & 341358 & 912434 & 48 & 140.06 & 188 & $03 / 26 / 07$ \\
\hline 05S05W36DAA1 & 341245 & 912947 & 35 & 145.24 & 180 & 03/26/07 \\
\hline 06S02W06ABB1 & 341228 & 911620 & 66 & 115.17 & 181 & 03/27/07 \\
\hline 06S02W17ADA1 & 341023 & 911453 & 73 & 115.11 & 188 & 03/27/07 \\
\hline 06S02W22CDB1 & 340904 & 911331 & 74 & 112.18 & 186 & 03/27/07 \\
\hline 06S03W27BAA1 & 340859 & 912009 & 61 & 119.92 & 181 & 03/27/07 \\
\hline 07S02W28ABA1 & 340340 & 911411 & 75 & 106.08 & 181 & $03 / 27 / 07$ \\
\hline 07S03W06ABC1 & 340702 & 912248 & 55 & 130.28 & 185 & 03/26/07 \\
\hline 08S02W09BCC1 & 340031 & 911448 & 73 & 100.92 & 174 & 03/27/07 \\
\hline
\end{tabular}


Appendix 1. Water-level data collected during spring 2007 from wells completed in the Sparta-Memphis aquifer in Arkansas.-Continued

[NGVD of 1929, National Geodetic Vertical Datum; Horizontal datum is North American Datum of 1983]

\begin{tabular}{|c|c|c|c|c|c|c|}
\hline Station name & $\begin{array}{l}\text { Latitude } \\
\text { (degrees, } \\
\text { minutes, } \\
\text { seconds) }\end{array}$ & $\begin{array}{l}\text { Longitude } \\
\text { (degrees, } \\
\text { minutes, } \\
\text { seconds) }\end{array}$ & $\begin{array}{c}\text { Water-level } \\
\text { altitude } \\
\text { (feet above } \\
\text { NGVD of 1929) }\end{array}$ & $\begin{array}{l}\text { Depth to water } \\
\text { (feet below } \\
\text { land surface) }\end{array}$ & $\begin{array}{c}\text { Land-surface } \\
\text { datum } \\
\text { (feet above } \\
\text { NGVD of 1929) }\end{array}$ & $\begin{array}{c}\text { Date of } \\
\text { measurement }\end{array}$ \\
\hline \multicolumn{7}{|c|}{ Ashley County } \\
\hline 15S07W32CDD1 & 332118 & 915101 & 42 & 148.25 & 190 & 03/20/07 \\
\hline 17S09W15ACC1 & 331334 & 920116 & 82 & 17.59 & 100 & $03 / 20 / 07$ \\
\hline \multicolumn{7}{|c|}{ Bradley County } \\
\hline 12S09W31CCB1 & 333711 & 920444 & 36 & 194.72 & 231 & 03/19/07 \\
\hline 13S09W06ACA1 & 333648 & 920437 & 15 & 220.18 & 235 & $04 / 25 / 07$ \\
\hline 13S09W06ACB2 & 333647 & 920417 & 29 & 179.00 & 208 & 03/19/07 \\
\hline 13S11W17BCD1 & 333454 & 921607 & 48 & 202.22 & 250 & 03/19/07 \\
\hline 16S12W21CAA1 & 331839 & 922052 & 21 & 79.02 & 100 & 03/19/07 \\
\hline \multicolumn{7}{|c|}{ Calhoun County } \\
\hline 11S14W12CAC3 & 334630 & 922928 & 175 & 138.00 & 313 & 03/29/07 \\
\hline 13S13W32CDA1 & 333227 & 922742 & 13 & 194.83 & 208 & 03/16/07 \\
\hline 13S15W36CBD1 & 333227 & 923532 & 76 & 82.47 & 158 & 03/20/07 \\
\hline 14S13W03CAB1 & 333145 & 922551 & 34 & 167.59 & 202 & 03/20/07 \\
\hline 14S13W05BBD1 & 333207 & 922802 & 32 & 156.80 & 189 & 03/20/07 \\
\hline 14S13W12CCB1 & 333040 & 922404 & 33 & 171.60 & 205 & 03/20/07 \\
\hline 15S13W20BDC1 & 332411 & 922807 & 85 & 24.42 & 109 & 03/20/07 \\
\hline \multicolumn{7}{|c|}{ Chicot County } \\
\hline 13S03W22DAD1 & 333312 & 912308 & 65 & 70.10 & 135 & 03/19/07 \\
\hline 15S03W07BCC1 & 332445 & 912723 & 64 & 65.11 & 129 & 03/20/07 \\
\hline \multicolumn{7}{|c|}{ Cleveland County } \\
\hline 09S09W04BBD1 & 335820 & 920237 & 85 & 223.20 & 308 & 03/21/07 \\
\hline 09S11W01DCA1 & 335729 & 921134 & 18 & 206.97 & 225 & $03 / 21 / 07$ \\
\hline 09S11W11CDB1 & 335623 & 921251 & 70 & 162.62 & 233 & 03/21/07 \\
\hline 10S09W23CDC1 & 334918 & 920021 & 56 & 164.12 & 220 & $03 / 21 / 07$ \\
\hline 10S09W35ACD1 & 334758 & 915957 & 63 & 156.42 & 219 & $03 / 21 / 07$ \\
\hline 10S12W12BDD1 & 335133 & 921743 & 100 & 120.26 & 220 & 03/21/07 \\
\hline 11S11W16AAB1 & 334543 & 921423 & 99 & 204.31 & 303 & 03/21/07 \\
\hline \multicolumn{7}{|c|}{ Columbia County } \\
\hline 16S20W08DCC1 & 332114 & 931141 & 83 & 319.33 & 402 & 03/16/07 \\
\hline 16S20W18ACD1 & 332053 & 931237 & 73 & 263.82 & 337 & 03/16/07 \\
\hline 17S19W15AAB1 & 331546 & 930318 & 42 & 265.73 & 318 & 03/16/07 \\
\hline 17S19W19BCA1 & 331433 & 930705 & 32 & 268.97 & 301 & 03/21/07 \\
\hline 17S20W17CDA1 & 331520 & 931201 & 11 & 313.96 & 325.1 & $03 / 21 / 07$ \\
\hline 17S20W36ABC1 & 331307 & 930755 & 42 & 292.66 & 335 & 03/21/07 \\
\hline 17S21W11DCC2 & 331609 & 931449 & 24 & 276.11 & 300 & 03/14/07 \\
\hline 17S21W11DCC3 & 331609 & 931449 & 20 & 277.89 & 298 & $03 / 21 / 07$ \\
\hline
\end{tabular}


Appendix 1. Water-level data collected during spring 2007 from wells completed in the Sparta-Memphis aquifer in Arkansas.-Continued

[NGVD of 1929, National Geodetic Vertical Datum; Horizontal datum is North American Datum of 1983]

\begin{tabular}{|c|c|c|c|c|c|c|}
\hline Station name & $\begin{array}{l}\text { Latitude } \\
\text { (degrees, } \\
\text { minutes, } \\
\text { seconds) }\end{array}$ & $\begin{array}{l}\text { Longitude } \\
\text { (degrees, } \\
\text { minutes, } \\
\text { seconds) }\end{array}$ & $\begin{array}{l}\text { Water-level } \\
\text { altitude } \\
\text { (feet above } \\
\text { NGVD of 1929) }\end{array}$ & $\begin{array}{l}\text { Depth to water } \\
\text { (feet below } \\
\text { land surface) }\end{array}$ & $\begin{array}{c}\text { Land-surface } \\
\text { datum } \\
\text { (feet above } \\
\text { NGVD of 1929) }\end{array}$ & $\begin{array}{c}\text { Date of } \\
\text { measurement }\end{array}$ \\
\hline \multicolumn{7}{|c|}{ Columbia County-Continued } \\
\hline 18S21W17ACD1 & 331034 & 931759 & 85 & 230.38 & 315 & $03 / 21 / 07$ \\
\hline 19S20W09CBD1 & 330555 & 931129 & 69 & 263.22 & 332 & $03 / 21 / 07$ \\
\hline 19S21W16DBB1 & 330517 & 931724 & 109 & 175.30 & 284 & 03/15/07 \\
\hline 19S23W10ABD1 & 330644 & 932833 & 196 & 45.57 & 242 & 03/15/07 \\
\hline 19S23W11CDA2 & 330609 & 932744 & 195 & 53.07 & 248 & 03/15/07 \\
\hline 19S23W11DDB1 & 330605 & 932722 & 192 & 53.82 & 246 & 03/15/07 \\
\hline 19S23W14BAB2 & 330555 & 932752 & 191 & 52.58 & 244 & 03/15/07 \\
\hline 20S22W03DCC1 & 330138 & 932236 & 161 & 52.85 & 214 & 03/15/07 \\
\hline 20S22W11ACD1 & 330109 & 932133 & 163 & 108.04 & 271 & 03/15/07 \\
\hline \multicolumn{7}{|c|}{ Craighead County } \\
\hline 13N03E23CDD1 & 354404 & 904433 & 159 & 88.76 & 248 & 04/18/07 \\
\hline 14N04E22CBD1 & 354929 & 903921 & 199 & 57.38 & 256 & 04/18/07 \\
\hline 14N04E28DBD1 & 354837 & 903953 & 192 & 62.48 & 254 & $04 / 18 / 07$ \\
\hline 14N05E36CBC1 & 354751 & 903100 & 208 & 12.40 & 220 & 04/18/07 \\
\hline 15N05E29DBB1 & 355360 & 903433 & 234 & 23.89 & 258 & 04/18/07 \\
\hline 15N06E18ACA1 & 355544 & 902858 & 213 & 17.26 & 230 & $04 / 18 / 07$ \\
\hline \multicolumn{7}{|c|}{ Crittenden County } \\
\hline 05N08E11CCA2 & 350345 & 901300 & 183 & 27.91 & 211 & $04 / 12 / 07$ \\
\hline 06N07E01DAD2 & 350958 & 901738 & 183 & 26.28 & 209 & $04 / 12 / 07$ \\
\hline 06N09E23AAB1 & 350745 & 900553 & 167 & 54.51 & 222 & $04 / 12 / 07$ \\
\hline 07N09E14BAC1 & 351348 & 900628 & 185 & 32.26 & 217 & $04 / 12 / 07$ \\
\hline 09N07E21BBB1 & 352341 & 902131 & 191 & 24.87 & 216 & $04 / 12 / 07$ \\
\hline Ar:C-001 & 350958 & 901738 & 185 & 26.60 & 212 & $03 / 29 / 07$ \\
\hline Ar:H-002 & 350344 & 901300 & 183 & 28.08 & 211 & 03/29/07 \\
\hline \multicolumn{7}{|c|}{ Cross County } \\
\hline 06N04E06ACA1 & 351004 & 904238 & 152 & 206.34 & 358 & 04/13/07 \\
\hline 07N05E04ADD1 & 351538 & 903330 & 173 & 35.51 & 209 & $04 / 19 / 07$ \\
\hline 09N01E16CAC1 & 352405 & 905951 & 142 & 92.09 & 234 & $04 / 13 / 07$ \\
\hline 09N01E25AAD1 & 352244 & 905554 & 138 & 89.48 & 227 & $04 / 13 / 07$ \\
\hline 09N03E22AAB2 & 352404 & 904518 & 149 & 127.98 & 277 & 04/17/07 \\
\hline 09N03E22AAD1 & 352403 & 904512 & 145 & 133.06 & 278 & $04 / 17 / 07$ \\
\hline 09N04E30DCA1 & 352232 & 904218 & 158 & 271.73 & 429.32 & 04/19/07 \\
\hline \multicolumn{7}{|c|}{ Dallas County } \\
\hline 07S14W30DCC1 & 340431 & 923360 & 215 & 120.35 & 335 & 03/13/07 \\
\hline 07S14W31AAA1 & 340425 & 923334 & 219 & 111.07 & 330 & 03/13/07 \\
\hline 07S16W20CAB1 & 340555 & 924545 & 294 & 28.46 & 322 & 03/13/07 \\
\hline
\end{tabular}


Appendix 1. Water-level data collected during spring 2007 from wells completed in the Sparta-Memphis aquifer in Arkansas.-Continued

[NGVD of 1929, National Geodetic Vertical Datum; Horizontal datum is North American Datum of 1983]

\begin{tabular}{|c|c|c|c|c|c|c|}
\hline Station name & $\begin{array}{l}\text { Latitude } \\
\text { (degrees, } \\
\text { minutes, } \\
\text { seconds) }\end{array}$ & $\begin{array}{l}\text { Longitude } \\
\text { (degrees, } \\
\text { minutes, } \\
\text { seconds) }\end{array}$ & $\begin{array}{c}\text { Water-level } \\
\text { altitude } \\
\text { (feet above } \\
\text { NGVD of 1929) }\end{array}$ & $\begin{array}{l}\text { Depth to water } \\
\text { (feet below } \\
\text { land surface) }\end{array}$ & $\begin{array}{c}\text { Land-surface } \\
\text { datum } \\
\text { (feet above } \\
\text { NGVD of 1929) }\end{array}$ & $\begin{array}{c}\text { Date of } \\
\text { measurement }\end{array}$ \\
\hline \multicolumn{7}{|c|}{ Dallas County-Continued } \\
\hline 08S15W34BDC1 & 335859 & 923730 & 213 & 26.67 & 240 & 03/13/07 \\
\hline 08S16W18ACC1 & 340152 & 924639 & 235 & 16.86 & 252 & 03/13/07 \\
\hline 08S16W27DDD1 & 335937 & 924307 & 241 & 33.66 & 275 & 03/13/07 \\
\hline 09S13W35CCD1 & 335309 & 922413 & 128 & 71.62 & 200 & 03/13/07 \\
\hline 09S14W01BDC1 & 335754 & 922919 & 182 & 82.92 & 265 & 03/13/07 \\
\hline 09S16W19CAA1 & 335605 & 924701 & 253 & 7.31 & 260 & 03/14/07 \\
\hline 10S13W34ACA2 & 334829 & 922458 & 121 & 151.38 & 272 & 03/13/07 \\
\hline 10S14W27CDB1 & 334908 & 923138 & 237 & 33.44 & 270 & 03/13/07 \\
\hline 10S15W18BCC1 & 335120 & 924120 & 249 & 79.05 & 328 & 03/14/07 \\
\hline \multicolumn{7}{|c|}{ Desha County } \\
\hline 09S02W26AAC1 & 335346 & 911521 & 80 & 72.64 & 153 & 03/19/07 \\
\hline 09S04W28DDD1 & 335310 & 913007 & 50 & 115.48 & 165 & 03/19/07 \\
\hline 10S02W26CCC2 & 334750 & 911624 & 72 & 75.97 & 148 & 03/19/07 \\
\hline 10S04W11CBC1 & 335034 & 912905 & 55 & 105.61 & 161 & 03/19/07 \\
\hline 11S02W03CCA1 & 334616 & 911711 & 64 & 74.73 & 139 & 03/19/07 \\
\hline 12S03W26CBB1 & 333749 & 912259 & 43 & 100.29 & 143 & 03/19/07 \\
\hline 12S03W34DAD1 & 333643 & 912305 & 65 & 82.21 & 147 & 03/19/07 \\
\hline \multicolumn{7}{|c|}{ Drew County } \\
\hline 11S04W02ACA2 & 334632 & 912827 & 57 & 96.09 & 153 & 03/20/07 \\
\hline 11S04W25CB2 & 334249 & 912707 & 60 & 88.18 & 148 & 03/20/07 \\
\hline 11S06W11DBC1 & 334607 & 914122 & 52 & 150.59 & 203 & 03/20/07 \\
\hline 12S06W30BBD1 & 333807 & 914543 & 44 & 226.62 & 271 & 03/20/07 \\
\hline 12S06W32DAD1 & 333649 & 914402 & 38 & 177.16 & 215 & 03/20/07 \\
\hline 13S05W36ACB1 & 333151 & 913408 & 77 & 92.23 & 169 & 03/20/07 \\
\hline 15S04W12DDA1 & 332429 & 912724 & 61 & 63.68 & 125 & 03/20/07 \\
\hline \multicolumn{7}{|c|}{ Grant County } \\
\hline 03S13W12AAA1 & 342846 & 922106 & 229 & 132.41 & 361 & 03/22/07 \\
\hline 03S15W26DAA1 & 342601 & 923447 & 326 & 11.02 & 337 & 03/22/07 \\
\hline 04S14W14CCC1 & 342201 & 922932 & 219 & 83.59 & 303 & $03 / 22 / 07$ \\
\hline 05S13W03CAA1 & 341844 & 922400 & 172 & 88.26 & 260 & $03 / 22 / 07$ \\
\hline 05S13W03CDA4 & 341838 & 922402 & 167 & 113.93 & 281 & $03 / 22 / 07$ \\
\hline 05S13W07ADB1 & 341810 & 922650 & 188 & 81.75 & 270 & 03/22/07 \\
\hline 05S13W30AAA1 & 341550 & 922650 & 201 & 129.14 & 330 & $03 / 22 / 07$ \\
\hline 05S14W06DCC1 & 341843 & 923327 & 205 & 87.64 & 293 & 03/22/07 \\
\hline 05S15W05ABD1 & 341924 & 923827 & 222 & 14.29 & 236 & 03/22/07 \\
\hline
\end{tabular}


Appendix 1. Water-level data collected during spring 2007 from wells completed in the Sparta-Memphis aquifer in Arkansas.-Continued

[NGVD of 1929, National Geodetic Vertical Datum; Horizontal datum is North American Datum of 1983]

\begin{tabular}{|c|c|c|c|c|c|c|}
\hline Station name & $\begin{array}{l}\text { Latitude } \\
\text { (degrees, } \\
\text { minutes, } \\
\text { seconds) }\end{array}$ & $\begin{array}{c}\text { Longitude } \\
\text { (degrees, } \\
\text { minutes, } \\
\text { seconds) }\end{array}$ & $\begin{array}{c}\text { Water-level } \\
\text { altitude } \\
\text { (feet above } \\
\text { NGVD of 1929) }\end{array}$ & $\begin{array}{l}\text { Depth to water } \\
\text { (feet below } \\
\text { land surface) }\end{array}$ & $\begin{array}{c}\text { Land-surface } \\
\text { datum } \\
\text { (feet above } \\
\text { NGVD of 1929) }\end{array}$ & $\begin{array}{c}\text { Date of } \\
\text { measurement }\end{array}$ \\
\hline \multicolumn{7}{|c|}{ Grant County-Continued } \\
\hline 06S11W05ACD1 & 341341 & 921413 & 53 & 216.06 & 269 & $03 / 22 / 07$ \\
\hline 06S15W26ACA1 & 341022 & 923538 & 207 & 72.77 & 280 & $03 / 22 / 07$ \\
\hline 07S12W21BDB1 & 340558 & 921953 & 219 & 4.12 & 223 & $03 / 22 / 07$ \\
\hline \multicolumn{7}{|c|}{ Hot Spring County } \\
\hline 05S16W35ACA1 & 341460 & 924151 & 307 & 34.78 & 342 & 03/13/07 \\
\hline \multicolumn{7}{|c|}{ Jefferson County } \\
\hline 03S08W19BAD1 & 342624 & 915444 & 43 & 173.95 & 217 & 03/27/07 \\
\hline 03S08W19BBD1 & 342628 & 915505 & 34 & 181.23 & 215 & $03 / 27 / 07$ \\
\hline 03S08W19BDB1 & 342619 & 915455 & 37 & 177.88 & 215 & $03 / 27 / 07$ \\
\hline 03S09W23BBD1 & 342627 & 915713 & 37 & 186.85 & 224 & 03/27/07 \\
\hline 03S10W14CAD1 & 342659 & 920330 & 100 & 120.60 & 221 & 03/27/07 \\
\hline 03S10W27AAD1 & 342502 & 920434 & 85 & 136.63 & 222 & $03 / 27 / 07$ \\
\hline 03S11W22ABC1 & 342651 & 921058 & 134 & 176.45 & 310 & 03/27/07 \\
\hline 04S07W17BCC1 & 342140 & 914742 & -5 & 205.35 & 200 & 04/03/07 \\
\hline 04S08W35BBD1 & 341909 & 915056 & -16 & 215.50 & 200 & 03/27/07 \\
\hline 04S10W17BDA1 & 342212 & 920646 & 59 & 205.51 & 265 & $03 / 29 / 07$ \\
\hline 04S11W14BAD1 & 342220 & 921000 & 86 & 313.67 & 400 & $03 / 29 / 07$ \\
\hline 05S08W30ADB1 & 341452 & 915440 & -78 & 298.66 & 221 & 04/03/07 \\
\hline 05S09W19BAA3 & 341609 & 920131 & -48 & 273.60 & 226 & $03 / 29 / 07$ \\
\hline 05S09W24DBD1 & 341530 & 915556 & -71 & 279.23 & 208.17 & 04/03/07 \\
\hline 05S09W31DDC1 & 341337 & 920109 & -48 & 274.55 & 227 & 03/28/07 \\
\hline 05S10W11ACA1 & 341741 & 920322 & 9 & 225.57 & 235 & $03 / 29 / 07$ \\
\hline 05S10W16BAD1 & 341700 & 920549 & 31 & 246.27 & 277 & 03/29/07 \\
\hline 05S10W16DBB1 & 341635 & 920543 & 3 & 312.25 & 315 & 03/29/07 \\
\hline 05S10W16DBD1 & 341635 & 920534 & -9 & 311.38 & 302 & $03 / 29 / 07$ \\
\hline 06S08W16CCC1 & 341143 & 915517 & -53 & 255.56 & 202.42 & 04/03/07 \\
\hline 06S08W25ADC1 & 341025 & 915116 & -22 & 225.35 & 203.48 & 04/03/07 \\
\hline 06S09W17CAD1 & 341159 & 920207 & -31 & 263.78 & 233 & 03/28/07 \\
\hline 06S09W17CCA1 & 341152 & 920221 & -23 & 257.38 & 234.34 & 03/28/07 \\
\hline 06S10W23ACD1 & 341116 & 920508 & 8 & 230.84 & 239 & $03 / 28 / 07$ \\
\hline 06S10W23DBA1 & 341105 & 920506 & 4 & 248.12 & 252 & 03/28/07 \\
\hline 07S07W24BAB1 & 340633 & 914523 & 17 & 170.85 & 188 & 03/28/07 \\
\hline 07S10W24CAC1 & 340549 & 920421 & 52 & 258.80 & 311 & 03/28/07 \\
\hline \multicolumn{7}{|c|}{ Lafayette County } \\
\hline 16S23W12CAD1 & 332143 & 932609 & 244 & 77.88 & 322 & 03/14/07 \\
\hline 16S24W26AAC1 & 331950 & 933303 & 209 & 57.61 & 267 & $03 / 14 / 07$ \\
\hline
\end{tabular}


Appendix 1. Water-level data collected during spring 2007 from wells completed in the Sparta-Memphis aquifer in Arkansas.-Continued

[NGVD of 1929, National Geodetic Vertical Datum; Horizontal datum is North American Datum of 1983]

\begin{tabular}{|c|c|c|c|c|c|c|}
\hline Station name & $\begin{array}{l}\text { Latitude } \\
\text { (degrees, } \\
\text { minutes, } \\
\text { seconds) }\end{array}$ & $\begin{array}{l}\text { Longitude } \\
\text { (degrees, } \\
\text { minutes, } \\
\text { seconds) }\end{array}$ & $\begin{array}{c}\text { Water-level } \\
\text { altitude } \\
\text { (feet above } \\
\text { NGVD of 1929) }\end{array}$ & $\begin{array}{l}\text { Depth to water } \\
\text { (feet below } \\
\text { land surface) }\end{array}$ & $\begin{array}{c}\text { Land-surface } \\
\text { datum } \\
\text { (feet above } \\
\text { NGVD of 1929) }\end{array}$ & $\begin{array}{c}\text { Date of } \\
\text { measurement }\end{array}$ \\
\hline \multicolumn{7}{|c|}{ Lafayette County-Continued } \\
\hline 17S23W19ACC1 & 331520 & 933128 & 237 & 53.95 & 291 & 03/14/07 \\
\hline 17S24W23BBD1 & 331526 & 933403 & 226 & 35.42 & 261 & 03/14/07 \\
\hline 18S23W29ACC1 & 330911 & 933039 & 242 & 13.26 & 255 & $03 / 15 / 07$ \\
\hline 19S23W29BDB1 & 330352 & 933103 & 207 & 43.16 & 250 & $03 / 15 / 07$ \\
\hline 19S25W13CAB1 & 330555 & 933922 & 215 & 40.23 & 255 & 03/15/07 \\
\hline 20S23W05ADA1 & 330223 & 933026 & 207 & 34.97 & 242 & $03 / 15 / 07$ \\
\hline 20S23W05ADB1 & 330223 & 933036 & 201 & 40.96 & 242 & 03/15/07 \\
\hline \multicolumn{7}{|c|}{ Lee County } \\
\hline 01N04E09CDD1 & 344210 & 904119 & 146 & 62.21 & 208 & 04/09/07 \\
\hline 02N01E10CAD1 & 344743 & 905925 & 147 & 54.44 & 201 & 04/09/07 \\
\hline \multicolumn{7}{|c|}{ Lincoln County } \\
\hline 07S07W30CDC1 & 340444 & 915043 & 18 & 190.05 & 208 & 03/26/07 \\
\hline 08S05W03BAA2 & 340310 & 913454 & 28 & 152.46 & 180 & $03 / 26 / 07$ \\
\hline 08S05W35ACC1 & 335907 & 913337 & 14 & 152.15 & 166 & 03/26/07 \\
\hline 08S08W35DBB1 & 335858 & 915222 & 21 & 228.88 & 250 & $03 / 26 / 07$ \\
\hline 08S08W35DCB1 & 335851 & 915217 & 10 & 260.17 & 270 & $03 / 26 / 07$ \\
\hline 09S07W07DAD1 & 335634 & 915128 & 16 & 279.86 & 296 & 03/26/07 \\
\hline 09S07W08BCC & 335644 & 915118 & 33 & 259.39 & 292 & 03/26/07 \\
\hline \multicolumn{7}{|c|}{ Lonoke County } \\
\hline 01N07W03BCC1 & 344425 & 914503 & 92 & 131.22 & 223 & 04/02/07 \\
\hline 01S08W02DBD1 & 343855 & 914960 & 112 & 98.31 & 210 & 04/03/07 \\
\hline 02N07W06ACD1 & 344939 & 914737 & 115 & 125.85 & 241 & 04/04/07 \\
\hline 02N07W09AAA1 & 344906 & 914500 & 131 & 101.45 & 232 & 04/04/07 \\
\hline 02N07W22DBA1 & 344651 & 914426 & 95 & 131.71 & 227 & 04/02/07 \\
\hline 02N07W24DAC1 & 344650 & 914209 & 81 & 149.65 & 231 & 04/02/07 \\
\hline 02S07W08DCC1 & 343235 & 914700 & 59 & 143.40 & 202 & 04/04/07 \\
\hline 02S09W15BBB2 & 343247 & 915825 & 144 & 81.97 & 226 & 04/03/07 \\
\hline 03N07W03CAA1 & 345445 & 914426 & 155 & 79.98 & 235 & 04/04/07 \\
\hline 03N08W11ACD1 & 345403 & 914935 & 154 & 93.65 & 248 & $05 / 22 / 07$ \\
\hline 03N08W22DAD1 & 345205 & 915024 & 136 & 97.42 & 233 & $05 / 22 / 07$ \\
\hline 03N08W22DAD2 & 345205 & 915024 & 133 & 99.53 & 233 & $05 / 22 / 07$ \\
\hline 03N08W22DDD2 & 345152 & 915025 & 133 & 101.98 & 235 & 05/23/07 \\
\hline \multicolumn{7}{|c|}{ Miller County } \\
\hline 17S25W18CDB1 & 331605 & 934402 & 213 & 7.04 & 220 & 03/15/07 \\
\hline 19S27W10BBA1 & 330719 & 935345 & 319 & 1.48 & 320 & 03/15/07 \\
\hline
\end{tabular}


Appendix 1. Water-level data collected during spring 2007 from wells completed in the Sparta-Memphis aquifer in Arkansas.-Continued

[NGVD of 1929, National Geodetic Vertical Datum; Horizontal datum is North American Datum of 1983]

\begin{tabular}{|c|c|c|c|c|c|c|}
\hline Station name & $\begin{array}{c}\text { Latitude } \\
\text { (degrees, } \\
\text { minutes, } \\
\text { seconds) }\end{array}$ & $\begin{array}{c}\text { Longitude } \\
\text { (degrees, } \\
\text { minutes, } \\
\text { seconds) } \\
\end{array}$ & $\begin{array}{c}\text { Water-level } \\
\text { altitude } \\
\text { (feet above } \\
\text { NGVD of 1929) }\end{array}$ & $\begin{array}{l}\text { Depth to water } \\
\text { (feet below } \\
\text { land surface) }\end{array}$ & $\begin{array}{c}\text { Land-surface } \\
\text { datum } \\
\text { (feet above } \\
\text { NGVD of 1929) } \\
\end{array}$ & $\begin{array}{c}\text { Date of } \\
\text { measurement }\end{array}$ \\
\hline \multicolumn{7}{|c|}{ Mississippi County } \\
\hline 11N09E26AAD3 & 353302 & 900523 & 214 & 25.96 & 240 & $04 / 18 / 07$ \\
\hline \multicolumn{7}{|c|}{ Monroe County } \\
\hline 11N09E26ABA2 & 353304 & 900539 & 211 & 24.88 & 236 & 04/18/07 \\
\hline 01N03W14CCB1 & 344144 & 911801 & 96 & 75.96 & 172 & 04/04/07 \\
\hline 03N02W26DAB1 & 345042 & 911026 & 143 & 49.02 & 192 & 04/09/07 \\
\hline 04N02W28DDD4 & 345535 & 911221 & 159 & 32.68 & 192 & 04/09/07 \\
\hline 04N02W30BAC1 & 345617 & 911504 & 170 & 11.80 & 182 & 04/09/07 \\
\hline 04N02W30BAD1 & 345617 & 911515 & 161 & 15.07 & 176 & $04 / 09 / 07$ \\
\hline \multicolumn{7}{|c|}{ Ouachita County } \\
\hline 11S15W27ABD1 & 334441 & 923726 & 131 & 69.34 & 200 & $03 / 22 / 07$ \\
\hline 11S17W14CAC1 & 334631 & 924927 & 124 & 22.32 & 146 & 03/22/07 \\
\hline 11S17W36CCA1 & 334341 & 924834 & 124 & 9.43 & 133 & $04 / 26 / 07$ \\
\hline 12S15W09BBA1 & 334223 & 923922 & 160 & 52.90 & 213 & 03/22/07 \\
\hline 12S16W25BDC1 & 333929 & 924211 & 108 & 32.42 & 140 & $03 / 21 / 07$ \\
\hline 12S16W26ABD1 & 333946 & 924304 & 102 & 34.63 & 137 & $03 / 21 / 07$ \\
\hline 12S18W19CDC1 & 334014 & 925951 & 204 & 30.63 & 235 & 03/26/07 \\
\hline 12S18W25CAB1 & 333937 & 925442 & 108 & 78.56 & 187 & $04 / 30 / 07$ \\
\hline 12S19W14AAA1 & 334143 & 930105 & 230 & 7.45 & 237 & $03 / 26 / 07$ \\
\hline 12S19W35BDD1 & 333901 & 930146 & 190 & 160.25 & 350 & $03 / 26 / 07$ \\
\hline 13S16W28ADD1 & 333416 & 924451 & 73 & 33.28 & 106 & 03/21/07 \\
\hline 13S18W31BDD1 & 333343 & 925956 & 171 & 71.18 & 242 & 03/15/07 \\
\hline 13S19W28BCD1 & 333434 & 930418 & 192 & 38.21 & 230 & $03 / 26 / 07$ \\
\hline 14S17W02ABB1 & 333253 & 924927 & 114 & 16.80 & 131 & $04 / 26 / 07$ \\
\hline 14S17W05CAD1 & 333238 & 925255 & 120 & 37.24 & 157 & 04/17/07 \\
\hline 14S17W32CAD1 & 332803 & 925251 & 141 & 79.06 & 220 & $03 / 21 / 07$ \\
\hline 14S19W29ABB1 & 332941 & 930513 & 192 & 88.16 & 280 & 03/15/07 \\
\hline 15S15W32DBB2 & 332234 & 924027 & -50 & 169.42 & 119 & 03/15/07 \\
\hline 15S16W23DAC1 & 332417 & 924314 & 44 & 126.15 & 170 & $04 / 26 / 07$ \\
\hline 15S18W36ADD1 & 332311 & 925436 & 66 & 94.40 & 160 & 03/21/07 \\
\hline 15S19W10DCC1 & 332618 & 930318 & 140 & 69.86 & 210 & 04/26/07 \\
\hline 15S19W21CDD2 & 332438 & 930432 & 73 & 198.82 & 272 & $04 / 17 / 07$ \\
\hline \multicolumn{7}{|c|}{ Phillips County } \\
\hline 01S02E32DDC1 & 343324 & 905455 & 127 & 84.17 & 211 & 04/10/07 \\
\hline 02S02E01ADC1 & 343323 & 905056 & 141 & 35.17 & 176 & $04 / 10 / 07$ \\
\hline 02S04E02DAA1 & 343243 & 903844 & 126 & 132.52 & 259 & $04 / 10 / 07$ \\
\hline
\end{tabular}


Appendix 1. Water-level data collected during spring 2007 from wells completed in the Sparta-Memphis aquifer in Arkansas.-Continued

[NGVD of 1929, National Geodetic Vertical Datum; Horizontal datum is North American Datum of 1983]

\begin{tabular}{|c|c|c|c|c|c|c|}
\hline Station name & $\begin{array}{l}\text { Latitude } \\
\text { (degrees, } \\
\text { minutes, } \\
\text { seconds) }\end{array}$ & $\begin{array}{l}\text { Longitude } \\
\text { (degrees, } \\
\text { minutes, } \\
\text { seconds) }\end{array}$ & $\begin{array}{c}\text { Water-level } \\
\text { altitude } \\
\text { (feet above } \\
\text { NGVD of 1929) }\end{array}$ & $\begin{array}{l}\text { Depth to water } \\
\text { (feet below } \\
\text { land surface) }\end{array}$ & $\begin{array}{c}\text { Land-surface } \\
\text { datum } \\
\text { (feet above } \\
\text { NGVD of 1929) }\end{array}$ & $\begin{array}{c}\text { Date of } \\
\text { measurement }\end{array}$ \\
\hline \multicolumn{7}{|c|}{ Phillips County-Continued } \\
\hline 02S04E02DBA1 & 343243 & 903907 & 121 & 129.19 & 250 & 04/10/07 \\
\hline 02S05E16BCB1 & 343108 & 903526 & 155 & 35.11 & 190 & 04/10/07 \\
\hline 02S05E29CCC1 & 342851 & 903635 & 155 & 23.56 & 179 & 04/10/07 \\
\hline 03S03E30DAA1 & 342403 & 904915 & 137 & 35.05 & 172 & $04 / 11 / 07$ \\
\hline 04S02E25CCC1 & 341824 & 905121 & 128 & 37.67 & 166 & 04/10/07 \\
\hline \multicolumn{7}{|c|}{ Poinsett County } \\
\hline 10N01E12BDC1 & 353026 & 905630 & 134 & 100.38 & 234 & 04/18/07 \\
\hline 10N01E15DBB1 & 352931 & 905825 & 135 & 96.92 & 232 & 04/18/07 \\
\hline 10N01E33ABA1 & 352725 & 905924 & 142 & 79.50 & 221 & 04/18/07 \\
\hline 10N03E02BCD1 & 353139 & 904447 & 139 & 111.68 & 251 & 04/18/07 \\
\hline 10N03E23CAC1 & 352850 & 904432 & 145 & 113.12 & 258 & 04/18/07 \\
\hline 11N02E16CCC1 & 353448 & 905321 & 134 & 108.69 & 243 & 04/18/07 \\
\hline 11N03E25BDD & 353328 & 904323 & 150 & 126.96 & 277 & 04/18/07 \\
\hline 11N03E25BDD1 & 353325 & 904323 & 148 & 121.45 & 269 & 04/17/07 \\
\hline 12N03E12BBB1 & 354137 & 904340 & 134 & 112.28 & 246 & 04/18/07 \\
\hline 12N03E35BCC1 & 353745 & 904456 & 143 & 100.53 & 244 & 04/18/07 \\
\hline 12N03E35DDA1 & 353727 & 904353 & 144 & 102.95 & 247 & 04/18/07 \\
\hline \multicolumn{7}{|c|}{ Prairie County } \\
\hline 01N05W19CDC1 & 344113 & 913505 & 67 & 145.15 & 212 & $04 / 12 / 07$ \\
\hline 01N06W02ABB1 & 344442 & 913701 & 93 & 128.34 & 221 & $04 / 12 / 07$ \\
\hline 01N06W34CBB1 & 343943 & 913846 & 56 & 169.70 & 226 & $04 / 12 / 07$ \\
\hline 01S05W06BCB1 & 343904 & 913532 & 43 & 177.20 & 220 & $04 / 12 / 07$ \\
\hline 01S05W20ABB1 & 343640 & 913352 & 65 & 154.65 & 220 & 04/06/07 \\
\hline 01S06W11DBD1 & 343749 & 913654 & 48 & 177.82 & 226 & $04 / 12 / 07$ \\
\hline 02N04W19ACB1 & 344649 & 912802 & 145 & 66.13 & 211 & $04 / 11 / 07$ \\
\hline 02N06W04DBB1 & 344928 & 913852 & 129 & 106.45 & 235 & 04/19/07 \\
\hline 02N06W19AAB1 & 344718 & 914050 & 85 & 150.58 & 236 & 04/11/07 \\
\hline 02N06W20BCB1 & 344707 & 914033 & 89 & 147.18 & 236 & 04/11/07 \\
\hline 02N06W21DAD1 & 344644 & 913829 & 99 & 132.92 & 232 & $04 / 11 / 07$ \\
\hline 02N06W22BDD1 & 344654 & 913801 & 105 & 127.90 & 233 & 04/11/07 \\
\hline 03N05W03ADA2 & 345452 & 913043 & 145 & 59.90 & 205 & 04/06/07 \\
\hline 03N05W20CCC1 & 345145 & 913356 & 141 & 71.89 & 213 & 04/06/07 \\
\hline 03N06W20CDD1 & 345140 & 914004 & 139 & 85.88 & 225 & 04/06/07 \\
\hline \multicolumn{7}{|c|}{ St Francis County } \\
\hline 04N04E18BAB1 & 345743 & 904319 & 155 & 65.29 & 220 & 04/19/07 \\
\hline 03N01W33CDD1 & 345446 & 910635 & 139 & 71.24 & 210 & 04/04/07 \\
\hline
\end{tabular}


Appendix 1. Water-level data collected during spring 2007 from wells completed in the Sparta-Memphis aquifer in Arkansas.-Continued

[NGVD of 1929, National Geodetic Vertical Datum; Horizontal datum is North American Datum of 1983]

\begin{tabular}{|c|c|c|c|c|c|c|}
\hline Station name & $\begin{array}{c}\text { Latitude } \\
\text { (degrees, } \\
\text { minutes, } \\
\text { seconds) }\end{array}$ & $\begin{array}{c}\text { Longitude } \\
\text { (degrees, } \\
\text { minutes, } \\
\text { seconds) }\end{array}$ & $\begin{array}{c}\text { Water-level } \\
\text { altitude } \\
\text { (feet above } \\
\text { NGVD of 1929) }\end{array}$ & $\begin{array}{l}\text { Depth to water } \\
\text { (feet below } \\
\text { land surface) }\end{array}$ & $\begin{array}{c}\text { Land-surface } \\
\text { datum } \\
\text { (feet above } \\
\text { NGVD of 1929) }\end{array}$ & $\begin{array}{c}\text { Date of } \\
\text { measurement }\end{array}$ \\
\hline \multicolumn{7}{|c|}{ Union County } \\
\hline 16S14W15CAB1 & 331944 & 923218 & -56 & 149.70 & 94 & 03/08/07 \\
\hline 16S15W20DAA1 & 331860 & 923958 & -65 & 254.70 & 190 & $02 / 23 / 07$ \\
\hline 16S15W31ACC1 & 331717 & 924129 & -98 & 265.72 & 168 & 03/15/07 \\
\hline 16S16W02ABC1 & 332206 & 924329 & -47 & 162.53 & 116 & 03/14/07 \\
\hline 16S18W34ABC2 & 331806 & 925709 & 41 & 209.53 & 251 & $02 / 23 / 07$ \\
\hline 17S12W31DDD1 & 331206 & 922226 & -8 & 228.07 & 220 & $03 / 22 / 07$ \\
\hline 17S12W32BBC1 & 331202 & 922219 & -11 & 241.54 & 231 & 02/23/07 \\
\hline 17S13W31BAC1 & 331200 & 922916 & -93 & 309.04 & 216 & 03/08/07 \\
\hline 17S14W22BAB1 & 331354 & 923224 & -97 & 297.61 & 201 & 03/14/07 \\
\hline 17S15W08CDD1 & 331505 & 924027 & -115 & 289.65 & 174.92 & $03 / 22 / 07$ \\
\hline 17S15W18DBB1 & 331439 & 924129 & -118 & 301.33 & 182.93 & $03 / 14 / 07$ \\
\hline 17S15W28DBA1 & 331246 & 923910 & -116 & 345.83 & 230 & 03/14/07 \\
\hline 17S15W28DCC1 & 331233 & 923924 & -138 & 422.88 & 285 & $03 / 22 / 07$ \\
\hline 17S15W29CDC1 & 331229 & 924039 & -142 & 361.79 & 220 & $03 / 22 / 07$ \\
\hline 17S15W31DCA1 & 331145 & 924117 & -125 & 396.61 & 272 & 03/07/07 \\
\hline 17S15W31DDA1 & 331144 & 924105 & -122 & 383.42 & 261 & 03/14/07 \\
\hline 17S16W01BAA1 & 331649 & 924233 & -83 & 271.73 & 188.84 & $03 / 21 / 07$ \\
\hline 17S16W02CCC1 & 331559 & 924403 & -134 & 316.37 & 182 & $03 / 22 / 07$ \\
\hline 17S16W02DCD1 & 331602 & 924326 & -154 & 375.78 & 222 & $03 / 22 / 07$ \\
\hline 17S16W12CDD1 & 331506 & 924232 & -161 & 382.38 & 221.58 & $03 / 22 / 07$ \\
\hline 17S16W24BDB1 & 331357 & 924248 & -139 & 343.85 & 205 & 03/09/07 \\
\hline 17S17W25DBA2 & 331256 & 924838 & -86 & 336.42 & 250 & 03/14/07 \\
\hline 17S17W30DCD1 & 331257 & 925356 & -44 & 323.53 & 280 & $03 / 21 / 07$ \\
\hline 18S11W09ABC1 & 331012 & 921443 & 40 & 94.64 & 135 & $03 / 22 / 07$ \\
\hline 18S12W33BBB1 & 330651 & 922120 & -28 & 139.56 & 112 & $02 / 23 / 07$ \\
\hline 18S14W06CCD1 & 331039 & 923531 & -111 & 342.80 & 232 & $02 / 23 / 07$ \\
\hline 18S15W03DAB1 & 331104 & 923802 & -106 & 346.05 & 240 & 03/14/07 \\
\hline 18S15W07BAC2 & 331035 & 924139 & -92 & 344.62 & 253 & $03 / 21 / 07$ \\
\hline 18S15W33ADA1 & 330659 & 923858 & -107 & 359.87 & 253 & 03/21/07 \\
\hline 18S15W35DAC1 & 330636 & 923707 & -83 & 283.78 & 201 & $03 / 21 / 07$ \\
\hline 18S16W10CDD1 & 331000 & 924445 & -133 & 314.68 & 182 & $03 / 21 / 07$ \\
\hline 18S16W11AAB1 & 331041 & 924314 & -112 & 337.30 & 225 & 03/14/07 \\
\hline 18S16W11DAC1 & 331011 & 924316 & -141 & 412.75 & 272 & $03 / 21 / 07$ \\
\hline 18S16W12ACB1 & 331029 & 924232 & -131 & 433.04 & 302 & 03/07/07 \\
\hline 18S16W28BBB1 & 330809 & 924611 & -94 & 319.20 & 225 & 03/07/07 \\
\hline 18S17W22BDD1 & 330856 & 925056 & -56 & 340.69 & 285 & 03/14/07 \\
\hline
\end{tabular}


Appendix 1. Water-level data collected during spring 2007 from wells completed in the Sparta-Memphis aquifer in Arkansas.-Continued

[NGVD of 1929, National Geodetic Vertical Datum; Horizontal datum is North American Datum of 1983]

\begin{tabular}{rcccccc}
\hline & $\begin{array}{c}\text { Latitude } \\
\text { (degrees, } \\
\text { minutes, } \\
\text { Seconds) }\end{array}$ & $\begin{array}{c}\text { Longitude } \\
\text { (degrees, } \\
\text { minutes, } \\
\text { seconds) }\end{array}$ & $\begin{array}{c}\text { Water-level } \\
\text { altitude } \\
\text { (feet above } \\
\text { NGVD of 1929) }\end{array}$ & $\begin{array}{c}\text { Depth to water } \\
\text { (feet below } \\
\text { land surface) }\end{array}$ & $\begin{array}{c}\text { Land-surface } \\
\text { datum } \\
\text { (feet above } \\
\text { NGVD of 1929) }\end{array}$ & $\begin{array}{c}\text { Date of } \\
\text { measurement }\end{array}$ \\
\hline 18S18W11ACD2 & 331051 & 925615 & -28 & 267.28 & 239 & $03 / 21 / 07$ \\
19S10W16CBC1 & 330329 & 920904 & -6 & 88.33 & 82 & $02 / 23 / 07$ \\
19S11W23ACA1 & 330255 & 921229 & -10 & 152.44 & 142 & $02 / 23 / 07$ \\
19S11W25AAA1 & 330218 & 921113 & -16 & 151.20 & 135 & $02 / 23 / 07$ \\
19S12W13AAA1 & 330411 & 921717 & 49 & 142.37 & 191 & $02 / 23 / 07$ \\
19S16W35DDC1 & 330109 & 924326 & -60 & 235.15 & 175 & $03 / 07 / 07$ \\
19S18W14ADA1 & 330452 & 925608 & 50 & 192.57 & 243 & $02 / 20 / 07$ \\
\hline & & & Woodruff County & & & \\
\hline 05N01W11ABA1 & 350426 & 910407 & 151 & 60.00 & 211 & $04 / 19 / 07$ \\
05N01W17DBB1 & 350311 & 910727 & 163 & 47.36 & 210 & $04 / 17 / 07$ \\
05N02W31DCB3 & 350027 & 911456 & 177 & 16.24 & 193 & $04 / 17 / 07$ \\
06N01W13ABA1 & 350852 & 910254 & 144 & 68.46 & 212 & $04 / 17 / 07$ \\
06N01W13ADC1 & 350827 & 910247 & 144 & 68.38 & 212 & $04 / 17 / 07$ \\
07N01W12BCB1 & 351442 & 910326 & 154 & 67.94 & 222 & $04 / 17 / 07$ \\
08N01W12CDA1 & 351934 & 910311 & 150 & 74.86 & 225 & $04 / 17 / 07$ \\
08N02W26ADC1 & 351726 & 911004 & 178 & 33.83 & 212 & $04 / 17 / 07$ \\
\hline
\end{tabular}


Appendix 2. Difference in water level from 2003 to 2007 in the Sparta-Memphis aquifer in Arkansas.

[Horizontal dautm is North American Datum of 1983; Negative values denote a decline, 2003 depth to water level from Schrader (2006)]

\begin{tabular}{|c|c|c|c|c|c|}
\hline Station name & $\begin{array}{l}\text { Latitude } \\
\text { (degrees, } \\
\text { minutes, } \\
\text { seconds) }\end{array}$ & $\begin{array}{l}\text { Longitude } \\
\text { (degrees, } \\
\text { minutes, } \\
\text { seconds) }\end{array}$ & $\begin{array}{c}2003 \text { depth } \\
\text { to water } \\
\text { (feet below land- } \\
\text { surface datum }\end{array}$ & $\begin{array}{c}2007 \text { depth } \\
\text { to water } \\
\text { (feet below land- } \\
\text { surface datum }\end{array}$ & $\begin{array}{c}\text { Difference in } \\
\text { water level from } \\
2003 \text { to } 2007 \\
\text { (feet) }\end{array}$ \\
\hline \multicolumn{6}{|c|}{ Arkansas County } \\
\hline 02S04W06CDB1 & 343312 & 912849 & 160.87 & 159.24 & 1.6 \\
\hline 02S04W23DAA1 & 343044 & 912355 & 149.72 & 144.91 & 4.8 \\
\hline 02S04W33BBB1 & 342922 & 912703 & 171.01 & 168.78 & 2.2 \\
\hline 02S05W16CBB1 & 343144 & 913319 & 178.88 & 172.95 & 5.9 \\
\hline 02S05W27BBB1 & 343028 & 913230 & 180.27 & 178.79 & 1.5 \\
\hline 02S05W34BDA1 & 342925 & 913148 & 179.8 & 180.13 & -0.3 \\
\hline 02S05W35AAB1 & 342930 & 913035 & 174.85 & 174.89 & 0.0 \\
\hline 03S04W02CCB1 & 342748 & 912458 & 162.24 & 153.4 & 8.8 \\
\hline 03S04W26CDA1 & 342421 & 912438 & 137.3 & 147.52 & -10.2 \\
\hline 03S05W02AAB1 & 342842 & 913034 & 173.43 & 173.32 & 0.1 \\
\hline 03S05W13BDC1 & 342631 & 913005 & 178.86 & 183.01 & -4.1 \\
\hline 03S05W15CBB1 & 342633 & 913229 & 171.95 & 179.22 & -7.3 \\
\hline 03S05W28DAB1 & 342447 & 913240 & 172.62 & 172.86 & -0.2 \\
\hline 03S06W30BBD1 & 342516 & 914216 & 160.74 & 157.4 & 3.3 \\
\hline 04S01W04CBD1 & 342225 & 910808 & 113.14 & 113.42 & -0.3 \\
\hline 04S01W28BAA1 & 341927 & 910748 & 106.16 & 106.52 & -0.4 \\
\hline 04S04W11BCC1 & 342157 & 912502 & 155.5 & 155.1 & 0.4 \\
\hline 04S04W19CBB1 & 342004 & 912929 & 162.72 & 163.58 & -0.9 \\
\hline 04S04W22DAA1 & 342007 & 912515 & 159.99 & 159.48 & 0.5 \\
\hline 04S05W05ACC1 & 342303 & 913413 & 157.42 & 159.4 & -2.0 \\
\hline 04S05W15AAA1 & 342132 & 913133 & 166.7 & 167.55 & -0.9 \\
\hline 04S05W36DCC1 & 341752 & 913004 & 163.18 & 166.15 & -3.0 \\
\hline 05S01W17BAA1 & 341551 & 910745 & 93.49 & 93.46 & 0.0 \\
\hline 05S03W04ADB1 & 341734 & 912007 & 160.84 & 140.31 & 20.5 \\
\hline 05S04W26ACA1 & 341358 & 912434 & 128.98 & 140.06 & -11.1 \\
\hline 06S02W06ABB1 & 341228 & 911620 & 114.76 & 115.17 & -0.4 \\
\hline 06S02W17ADA1 & 341023 & 911453 & 114.77 & 115.11 & -0.3 \\
\hline 06S02W22CDB1 & 340904 & 911331 & 105.86 & 112.18 & -6.3 \\
\hline 06S03W27BAA1 & 340859 & 912009 & 119.62 & 119.92 & -0.3 \\
\hline 07S02W28ABA1 & 340340 & 911411 & 105.64 & 106.08 & -0.4 \\
\hline 07S03W06ABC1 & 340702 & 912248 & 131.33 & 130.28 & 1.1 \\
\hline 08S02W09BCC1 & 340031 & 911448 & 100.22 & 100.92 & -0.7 \\
\hline \multicolumn{6}{|c|}{ Ashley County } \\
\hline 15S07W32CDD1 & 332118 & 915101 & 137.84 & 148.25 & -10.4 \\
\hline
\end{tabular}


Appendix 2. Difference in water level from 2003 to 2007 in the Sparta-Memphis aquifer in Arkansas.—Continued

[Horizontal dautm is North American Datum of 1983; Negative values denote a decline, 2003 depth to water level from Schrader (2006)]

\begin{tabular}{|c|c|c|c|c|c|}
\hline Station name & $\begin{array}{l}\text { Latitude } \\
\text { (degrees, } \\
\text { minutes, } \\
\text { seconds) }\end{array}$ & $\begin{array}{l}\text { Longitude } \\
\text { (degrees, } \\
\text { minutes, } \\
\text { seconds) }\end{array}$ & $\begin{array}{c}2003 \text { depth } \\
\text { to water } \\
\text { (feet below land- } \\
\text { surface datum }\end{array}$ & $\begin{array}{c}2007 \text { depth } \\
\text { to water } \\
\text { (feet below land- } \\
\text { surface datum }\end{array}$ & $\begin{array}{c}\text { Difference in } \\
\text { water level from } \\
2003 \text { to } 2007 \\
\text { (feet) }\end{array}$ \\
\hline \multicolumn{6}{|c|}{ Bradley County } \\
\hline 12S09W31CCB1 & 333711 & 920444 & 183.54 & 194.72 & -11.2 \\
\hline 13S09W06ACA1 & 333648 & 920437 & 183.67 & 220.18 & -36.5 \\
\hline 13S09W06ACB2 & 333647 & 920417 & 157.75 & 179 & -21.3 \\
\hline 13S11W17BCD1 & 333454 & 921607 & 193.43 & 202.22 & -8.8 \\
\hline 16S12W21CAA1 & 331839 & 922052 & 75.29 & 79.02 & -3.7 \\
\hline \multicolumn{6}{|c|}{ Calhoun County } \\
\hline 11S14W12CAC3 & 334630 & 922928 & 146 & 138 & 8.0 \\
\hline 13S13W32CDA1 & 333227 & 922742 & 168.68 & 194.83 & -26.2 \\
\hline 13S15W36CBD1 & 333227 & 923532 & 80.51 & 82.47 & -2.0 \\
\hline 14S13W05BBD1 & 333207 & 922802 & 154.13 & 156.8 & -2.7 \\
\hline 14S13W12CCB1 & 333040 & 922404 & 168.45 & 171.6 & -3.2 \\
\hline 15S13W20BDC1 & 332411 & 922807 & 34.11 & 24.42 & 9.7 \\
\hline \multicolumn{6}{|c|}{ Chicot County } \\
\hline 13S03W22DAD1 & 333312 & 912308 & 67.03 & 70.1 & -3.1 \\
\hline \multicolumn{6}{|c|}{ Cleveland County } \\
\hline 09S11W01DCA1 & 335729 & 921134 & 206.18 & 206.97 & -0.8 \\
\hline 10S09W23CDC1 & 334918 & 920021 & 161.88 & 164.12 & -2.2 \\
\hline 10S09W35ACD1 & 334758 & 915957 & 154.2 & 156.42 & -2.2 \\
\hline 10S12W12BDD1 & 335133 & 921743 & 117.29 & 120.26 & -3.0 \\
\hline 11S11W16AAB1 & 334543 & 921423 & 205.99 & 204.31 & 1.7 \\
\hline \multicolumn{6}{|c|}{ Columbia County } \\
\hline 16S20W08DCC1 & 332114 & 931141 & 315.1 & 319.33 & -4.2 \\
\hline 16S20W18ACD1 & 332053 & 931237 & 263.2 & 263.82 & -0.6 \\
\hline 17S19W15AAB1 & 331546 & 930318 & 272.37 & 275.73 & -3.4 \\
\hline 17S19W19BCA1 & 331433 & 930705 & 274.59 & 268.97 & 5.6 \\
\hline 17S20W17CDA1 & 331520 & 931201 & 303.03 & 313.96 & -10.9 \\
\hline 17S20W36ABC1 & 331307 & 930755 & 297 & 292.66 & 4.3 \\
\hline 17S21W11DCC2 & 331609 & 931449 & 283.08 & 275.09 & 8.0 \\
\hline 17S21W11DCC3 & 331609 & 931449 & 280.97 & 277.89 & 3.1 \\
\hline 18S21W17ACD1 & 331034 & 931759 & 236.4 & 230.38 & 6.0 \\
\hline 19S20W09CBD1 & 330555 & 931129 & 266.01 & 263.22 & 2.8 \\
\hline 19S21W16DBB1 & 330517 & 931724 & 174.42 & 175.3 & -0.9 \\
\hline 19S23W10ABD1 & 330644 & 932833 & 45.22 & 45.57 & -0.4 \\
\hline 19S23W11CDA2 & 330609 & 932744 & 52.65 & 53.07 & -0.4 \\
\hline 19S23W11DDB1 & 330605 & 932722 & 53.76 & 53.82 & -0.1 \\
\hline 19S23W14BAB2 & 330555 & 932752 & 49.99 & 52.58 & -2.6 \\
\hline
\end{tabular}


Appendix 2. Difference in water level from 2003 to 2007 in the Sparta-Memphis aquifer in Arkansas.-Continued

[Horizontal dautm is North American Datum of 1983; Negative values denote a decline, 2003 depth to water level from Schrader (2006)]

\begin{tabular}{|c|c|c|c|c|c|}
\hline Station name & $\begin{array}{l}\text { Latitude } \\
\text { (degrees, } \\
\text { minutes, } \\
\text { seconds) }\end{array}$ & $\begin{array}{c}\text { Longitude } \\
\text { (degrees, } \\
\text { minutes, } \\
\text { seconds) }\end{array}$ & $\begin{array}{c}2003 \text { depth } \\
\text { to water } \\
\text { (feet below land- } \\
\text { surface datum }\end{array}$ & $\begin{array}{c}2007 \text { depth } \\
\text { to water } \\
\text { (feet below land- } \\
\text { surface datum }\end{array}$ & $\begin{array}{c}\text { Difference in } \\
\text { water level from } \\
2003 \text { to } 2007 \\
\text { (feet) }\end{array}$ \\
\hline \multicolumn{6}{|c|}{ Columbia County-Continued } \\
\hline 20S22W11ACD1 & 330109 & 932133 & 107.17 & 108.04 & -0.9 \\
\hline \multicolumn{6}{|c|}{ Craighead County } \\
\hline 13N03E23CDD1 & 354404 & 904433 & 86.89 & 88.76 & -1.9 \\
\hline 14N04E22CBD1 & 354929 & 903921 & 55.7 & 57.38 & -1.7 \\
\hline 14N04E28DBD1 & 354837 & 903953 & 61.17 & 62.48 & -1.3 \\
\hline 14N05E36CBC1 & 354751 & 903100 & 12.1 & 12.4 & -0.3 \\
\hline 15N05E29DBB1 & 355360 & 903433 & 23.47 & 23.89 & -0.4 \\
\hline 15N06E18ACA1 & 355544 & 902858 & 18.36 & 17.26 & 1.1 \\
\hline \multicolumn{6}{|c|}{ Crittenden County } \\
\hline 05N08E11CCA2 & 350345 & 901300 & 25.97 & 27.91 & -1.9 \\
\hline 06N07E01DAD2 & 350958 & 901738 & 24.16 & 26.28 & -2.1 \\
\hline 06N09E23AAB1 & 350745 & 900553 & 64.36 & 54.51 & 9.9 \\
\hline 07N09E14BAC1 & 351348 & 900628 & 37.33 & 32.26 & 5.1 \\
\hline \multicolumn{6}{|c|}{ Cross County } \\
\hline 06N04E06ACA1 & 351004 & 904238 & 201.88 & 206.34 & -4.5 \\
\hline 07N05E04ADD1 & 351538 & 903330 & 35.26 & 35.51 & -0.3 \\
\hline 09N01E16CAC1 & 352405 & 905951 & 79.65 & 92.09 & -12.4 \\
\hline 09N01E25AAD1 & 352244 & 905554 & 84.32 & 89.48 & -5.2 \\
\hline 09N03E22AAB2 & 352404 & 904518 & 122.52 & 127.98 & -5.5 \\
\hline 09N03E22AAD1 & 352403 & 904512 & 134.5 & 133.06 & 1.4 \\
\hline 09N04E30DCA1 & 352232 & 904218 & 263.74 & 271.73 & -8.0 \\
\hline \multicolumn{6}{|c|}{ Dallas County } \\
\hline 07S14W30DCC1 & 340431 & 923360 & 119.75 & 120.35 & -0.6 \\
\hline 07S14W31AAA1 & 340425 & 923334 & 109.46 & 111.07 & -1.6 \\
\hline 07S16W20CAB1 & 340555 & 924545 & 24.37 & 28.46 & -4.1 \\
\hline 08S15W34BDC1 & 335859 & 923730 & 25.74 & 26.67 & -0.9 \\
\hline 08S16W18ACC1 & 340152 & 924639 & 15.78 & 16.86 & -1.1 \\
\hline 08S16W27DDD1 & 335937 & 924307 & 32.93 & 33.66 & -0.7 \\
\hline 09S13W35CCD1 & 335309 & 922413 & 71.61 & 71.62 & 0.0 \\
\hline 09S14W01BDC1 & 335754 & 922919 & 78.8 & 82.92 & -4.1 \\
\hline 09S16W19CAA1 & 335605 & 924701 & 6.51 & 7.31 & -0.8 \\
\hline 10S13W34ACA2 & 334829 & 922458 & 150.74 & 151.38 & -0.6 \\
\hline 10S14W27CDB1 & 334908 & 923138 & 35.03 & 33.44 & 1.6 \\
\hline 10S15W18BCC1 & 335120 & 924120 & 75.39 & 79.05 & -3.7 \\
\hline \multicolumn{6}{|c|}{ Desha County } \\
\hline 09S02W26AAC1 & 335346 & 911521 & 69.98 & 72.64 & -2.7 \\
\hline
\end{tabular}


Appendix 2. Difference in water level from 2003 to 2007 in the Sparta-Memphis aquifer in Arkansas.—Continued

[Horizontal dautm is North American Datum of 1983; Negative values denote a decline, 2003 depth to water level from Schrader (2006)]

\begin{tabular}{|c|c|c|c|c|c|}
\hline Station name & $\begin{array}{l}\text { Latitude } \\
\text { (degrees, } \\
\text { minutes, } \\
\text { seconds) }\end{array}$ & $\begin{array}{l}\text { Longitude } \\
\text { (degrees, } \\
\text { minutes, } \\
\text { seconds) }\end{array}$ & $\begin{array}{c}2003 \text { depth } \\
\text { to water } \\
\text { (feet below land- } \\
\text { surface datum }\end{array}$ & $\begin{array}{c}2007 \text { depth } \\
\text { to water } \\
\text { (feet below land- } \\
\text { surface datum }\end{array}$ & $\begin{array}{c}\text { Difference in } \\
\text { water level from } \\
2003 \text { to } 2007 \\
\text { (feet) }\end{array}$ \\
\hline \multicolumn{6}{|c|}{ Desha County-Continued } \\
\hline 09S04W28DDD1 & 335310 & 913007 & 112.42 & 115.48 & -3.1 \\
\hline 10S02W26CCC2 & 334750 & 911624 & 72.14 & 75.97 & -3.8 \\
\hline 10S04W11CBC1 & 335034 & 912905 & 102.45 & 105.61 & -3.2 \\
\hline 11S02W03CCA1 & 334616 & 911711 & 70.32 & 74.73 & -4.4 \\
\hline 12S03W26CBB1 & 333749 & 912259 & 96.12 & 100.29 & -4.2 \\
\hline 12S03W34DAD1 & 333643 & 912305 & 78.45 & 82.21 & -3.8 \\
\hline \multicolumn{6}{|c|}{ Drew County } \\
\hline 11S04W02ACA2 & 334632 & 912827 & 92.38 & 96.09 & -3.7 \\
\hline 11S04W25CB2 & 334249 & 912707 & 84.28 & 88.18 & -3.9 \\
\hline 11S06W11DBC1 & 334607 & 914122 & 149.95 & 150.59 & -0.6 \\
\hline 12S06W30BBD1 & 333807 & 914543 & 222.63 & 226.62 & -4.0 \\
\hline 12S06W32DAD1 & 333649 & 914402 & 168.02 & 177.16 & -9.1 \\
\hline 13S05W36ACB1 & 333151 & 913408 & 89.13 & 92.23 & -3.1 \\
\hline 15S04W12DDA1 & 332429 & 912724 & 62.02 & 63.68 & -1.7 \\
\hline \multicolumn{6}{|c|}{ Grant County } \\
\hline 03S13W12AAA1 & 342846 & 922106 & 131.45 & 132.41 & -1.0 \\
\hline 03S15W26DAA1 & 342601 & 923447 & 10.45 & 11.02 & -0.6 \\
\hline 04S14W14CCC1 & 342201 & 922932 & 83.05 & 83.59 & -0.5 \\
\hline 05S13W03CAA1 & 341844 & 922400 & 84.77 & 88.26 & -3.5 \\
\hline 05S13W03CDA4 & 341838 & 922402 & 111.9 & 113.93 & -2.0 \\
\hline 05S13W07ADB1 & 341810 & 922650 & 60.22 & 81.75 & -21.5 \\
\hline 05S13W30AAA1 & 341550 & 922650 & 120.65 & 129.14 & -8.5 \\
\hline 05S14W06DCC1 & 341843 & 923327 & 87.62 & 87.64 & 0.0 \\
\hline 05S15W05ABD1 & 341924 & 923827 & 19.03 & 14.29 & 4.7 \\
\hline 06S11W05ACD1 & 341341 & 921413 & 210.47 & 216.06 & -5.6 \\
\hline 06S15W26ACA1 & 341022 & 923538 & 66.34 & 72.77 & -6.4 \\
\hline 07S12W21BDB1 & 340558 & 921953 & 2.17 & 4.12 & -2.0 \\
\hline \multicolumn{6}{|c|}{ Hot Spring County } \\
\hline 05S16W35ACA1 & 341460 & 924151 & 35.67 & 34.78 & 0.9 \\
\hline \multicolumn{6}{|c|}{ Jefferson County } \\
\hline 03S08W19BAD1 & 342624 & 915444 & 169.65 & 173.95 & -4.3 \\
\hline 03S08W19BBD1 & 342628 & 915505 & 167.52 & 181.23 & -13.7 \\
\hline 03S08W19BDB1 & 342619 & 915455 & 167.55 & 177.88 & -10.3 \\
\hline 03S09W23BBD1 & 342627 & 915713 & 178.27 & 186.85 & -8.6 \\
\hline 03S10W14CAD1 & 342659 & 920330 & 116.83 & 120.6 & -3.8 \\
\hline 03S10W27AAD1 & 342502 & 920434 & 125.96 & 136.63 & -10.7 \\
\hline
\end{tabular}


Appendix 2. Difference in water level from 2003 to 2007 in the Sparta-Memphis aquifer in Arkansas.-Continued

[Horizontal dautm is North American Datum of 1983; Negative values denote a decline, 2003 depth to water level from Schrader (2006)]

\begin{tabular}{|c|c|c|c|c|c|}
\hline Station name & $\begin{array}{l}\text { Latitude } \\
\text { (degrees, } \\
\text { minutes, } \\
\text { seconds) }\end{array}$ & $\begin{array}{c}\text { Longitude } \\
\text { (degrees, } \\
\text { minutes, } \\
\text { seconds) }\end{array}$ & $\begin{array}{c}2003 \text { depth } \\
\text { to water } \\
\text { (feet below land- } \\
\text { surface datum }\end{array}$ & $\begin{array}{c}2007 \text { depth } \\
\text { to water } \\
\text { (feet below land- } \\
\text { surface datum }\end{array}$ & $\begin{array}{c}\text { Difference in } \\
\text { water level from } \\
2003 \text { to } 2007 \\
\text { (feet) }\end{array}$ \\
\hline \multicolumn{6}{|c|}{ Jefferson County-Continued } \\
\hline 03S11W22ABC1 & 342651 & 921058 & 175.34 & 176.45 & -1.1 \\
\hline 04S07W17BCC1 & 342140 & 914742 & 171.33 & 205.35 & -34.0 \\
\hline 04S08W35BBD1 & 341909 & 915056 & 211.75 & 215.5 & -3.8 \\
\hline 04S10W17BDA1 & 342212 & 920646 & 191.57 & 205.51 & -13.9 \\
\hline 04S11W14BAD1 & 342220 & 921000 & 308.55 & 313.67 & -5.1 \\
\hline 05S08W30ADB1 & 341452 & 915440 & 295.19 & 298.66 & -3.5 \\
\hline 05S09W19BAA3 & 341609 & 920131 & 255.57 & 273.6 & -18.0 \\
\hline 05S09W24DBD1 & 341530 & 915556 & 272.52 & 279.23 & -6.7 \\
\hline 05S09W31DDC1 & 341337 & 920109 & 286.14 & 274.55 & 11.6 \\
\hline 05S10W11ACA1 & 341741 & 920322 & 195.96 & 225.57 & -29.6 \\
\hline 05S10W16BAD1 & 341700 & 920549 & 244.92 & 246.27 & -1.4 \\
\hline 05S10W16DBB1 & 341635 & 920543 & 292.4 & 312.25 & -19.9 \\
\hline 05S10W16DBD1 & 341635 & 920534 & 279.75 & 311.38 & -31.6 \\
\hline 06S08W16CCC1 & 341143 & 915517 & 256.4 & 255.56 & 0.8 \\
\hline 06S08W25ADC1 & 341025 & 915116 & 217.39 & 225.35 & -8.0 \\
\hline 06S09W17CAD1 & 341159 & 920207 & 280.07 & 263.78 & 16.3 \\
\hline 06S09W17CCA1 & 341152 & 920221 & 269.28 & 257.38 & 11.9 \\
\hline 06S10W23ACD1 & 341116 & 920508 & 226.16 & 230.84 & -4.7 \\
\hline 06S10W23DBA1 & 341105 & 920506 & 239.96 & 248.12 & -8.2 \\
\hline 07S07W24BAB1 & 340633 & 914523 & 161.69 & 170.85 & -9.2 \\
\hline 07S10W24CAC1 & 340549 & 920421 & 302.05 & 258.8 & 43.3 \\
\hline \multicolumn{6}{|c|}{ Lafayette County } \\
\hline 16S23W12CAD1 & 332143 & 932609 & 73.11 & 77.88 & -4.8 \\
\hline 16S24W26AAC1 & 331950 & 933303 & 53.85 & 57.61 & -3.8 \\
\hline 17S23W19ACC1 & 331520 & 933128 & 51.12 & 53.95 & -2.8 \\
\hline 17S24W23BBD1 & 331526 & 933403 & 31.59 & 35.42 & -3.8 \\
\hline 18S23W29ACC1 & 330911 & 933039 & 12.57 & 13.26 & -0.7 \\
\hline 19S23W29BDB1 & 330352 & 933103 & 40.9 & 43.16 & -2.3 \\
\hline 19S25W13CAB1 & 330555 & 933922 & 37.1 & 40.23 & -3.1 \\
\hline 20S23W05ADA1 & 330223 & 933026 & 33.18 & 34.97 & -1.8 \\
\hline 20S23W05ADB1 & 330223 & 933036 & 38.69 & 40.96 & -2.3 \\
\hline \multicolumn{6}{|c|}{ Lee County } \\
\hline 01N04E09CDD1 & 344210 & 904119 & 59.28 & 62.21 & -2.9 \\
\hline 02N01E10CAD1 & 344743 & 905925 & 51.1 & 54.44 & -3.3 \\
\hline \multicolumn{6}{|c|}{ Lincoln County } \\
\hline 07S07W30CDC1 & 340444 & 915043 & 179.23 & 190.05 & -10.8 \\
\hline
\end{tabular}


Appendix 2. Difference in water level from 2003 to 2007 in the Sparta-Memphis aquifer in Arkansas.—Continued

[Horizontal dautm is North American Datum of 1983; Negative values denote a decline, 2003 depth to water level from Schrader (2006)]

\begin{tabular}{|c|c|c|c|c|c|}
\hline Station name & $\begin{array}{l}\text { Latitude } \\
\text { (degrees, } \\
\text { minutes, } \\
\text { seconds) }\end{array}$ & $\begin{array}{l}\text { Longitude } \\
\text { (degrees, } \\
\text { minutes, } \\
\text { seconds) }\end{array}$ & $\begin{array}{c}2003 \text { depth } \\
\text { to water } \\
\text { (feet below land- } \\
\text { surface datum }\end{array}$ & $\begin{array}{c}2007 \text { depth } \\
\text { to water } \\
\text { (feet below land- } \\
\text { surface datum }\end{array}$ & $\begin{array}{c}\text { Difference in } \\
\text { water level from } \\
2003 \text { to } 2007 \\
\text { (feet) }\end{array}$ \\
\hline \multicolumn{6}{|c|}{ Lincoln County-Continued } \\
\hline 08S05W03BAA2 & 340310 & 913454 & 145.14 & 152.46 & -7.3 \\
\hline 08S05W35ACC1 & 335907 & 913337 & 136.92 & 152.15 & -15.2 \\
\hline 08S08W35DBB1 & 335858 & 915222 & 201.56 & 228.88 & -27.3 \\
\hline 08S08W35DCB1 & 335851 & 915217 & 210.41 & 260.17 & -49.8 \\
\hline 09S07W07DAD1 & 335634 & 915128 & 268.2 & 279.86 & -11.7 \\
\hline \multicolumn{6}{|c|}{ Lonoke County } \\
\hline 01N07W03BCC1 & 344425 & 914503 & 127.59 & 131.22 & -3.6 \\
\hline 01S08W02DBD1 & 343855 & 914960 & 96.65 & 98.31 & -1.7 \\
\hline 02N07W06ACD1 & 344939 & 914737 & 122.12 & 125.85 & -3.7 \\
\hline 02N07W09AAA1 & 344906 & 914500 & 98.64 & 101.45 & -2.8 \\
\hline 02N07W22DBA1 & 344651 & 914426 & 126.17 & 131.71 & -5.5 \\
\hline 02N07W24DAC1 & 344650 & 914209 & 143.96 & 149.65 & -5.7 \\
\hline 02S09W15BBB2 & 343247 & 915825 & 72.99 & 81.97 & -9.0 \\
\hline 03N07W03CAA1 & 345445 & 914426 & 79.11 & 79.98 & -0.9 \\
\hline 03N08W11ACD1 & 345403 & 914935 & 88.65 & 93.65 & -5.0 \\
\hline 03N08W22DAD1 & 345205 & 915024 & 86.56 & 97.42 & -10.9 \\
\hline 03N08W22DAD2 & 345205 & 915024 & 93.37 & 99.53 & -6.2 \\
\hline 03N08W22DDD2 & 345152 & 915025 & 95 & 101.98 & -7.0 \\
\hline \multicolumn{6}{|c|}{ Mississippi County } \\
\hline 11N09E26AAD3 & 353302 & 900523 & 21.75 & 25.96 & -4.2 \\
\hline 11N09E26ABA2 & 353304 & 900539 & 17.73 & 24.88 & -7.2 \\
\hline \multicolumn{6}{|c|}{ Monroe County } \\
\hline 01N03W14CCB1 & 344144 & 911801 & 71.29 & 75.96 & -4.7 \\
\hline 03N02W26DAB1 & 345042 & 911026 & 46.87 & 49.02 & -2.2 \\
\hline 04N02W28DDD4 & 345535 & 911221 & 30.06 & 32.68 & -2.6 \\
\hline 04N02W30BAC1 & 345617 & 911504 & 15.16 & 11.8 & 3.4 \\
\hline 04N02W30BAD1 & 345617 & 911515 & 9.09 & 15.07 & -6.0 \\
\hline \multicolumn{6}{|c|}{ Ouachita County } \\
\hline 11S15W27ABD1 & 334441 & 923726 & 67.03 & 69.34 & -2.3 \\
\hline 11S17W14CAC1 & 334631 & 924927 & 19.59 & 22.32 & -2.7 \\
\hline 11S17W36CCA1 & 334341 & 924834 & 7.43 & 9.43 & -2.0 \\
\hline 12S15W09BBA1 & 334223 & 923922 & 68.75 & 52.9 & 15.9 \\
\hline 12S16W25BDC1 & 333929 & 924211 & 33.1 & 32.42 & 0.7 \\
\hline 12S16W26ABD1 & 333946 & 924304 & 42.32 & 34.63 & 7.7 \\
\hline 12S18W25CAB1 & 333937 & 925442 & 77.29 & 78.56 & -1.3 \\
\hline
\end{tabular}


Appendix 2. Difference in water level from 2003 to 2007 in the Sparta-Memphis aquifer in Arkansas.-Continued

[Horizontal dautm is North American Datum of 1983; Negative values denote a decline, 2003 depth to water level from Schrader (2006)]

\begin{tabular}{|c|c|c|c|c|c|}
\hline Station name & $\begin{array}{l}\text { Latitude } \\
\text { (degrees, } \\
\text { minutes, } \\
\text { seconds) }\end{array}$ & $\begin{array}{c}\text { Longitude } \\
\text { (degrees, } \\
\text { minutes, } \\
\text { seconds) }\end{array}$ & $\begin{array}{c}2003 \text { depth } \\
\text { to water } \\
\text { (feet below land- } \\
\text { surface datum }\end{array}$ & $\begin{array}{c}2007 \text { depth } \\
\text { to water } \\
\text { (feet below land- } \\
\text { surface datum }\end{array}$ & $\begin{array}{c}\text { Difference in } \\
\text { water level from } \\
2003 \text { to } 2007 \\
\text { (feet) }\end{array}$ \\
\hline \multicolumn{6}{|c|}{ Ouachita County-Continued } \\
\hline 12S19W14AAA1 & 334143 & 930105 & 4.36 & 7.45 & -3.1 \\
\hline 12S19W35BDD1 & 333901 & 930146 & 154.95 & 160.25 & -5.3 \\
\hline 13S16W28ADD1 & 333416 & 924451 & 24.35 & 33.28 & -8.9 \\
\hline 13S19W28BCD1 & 333434 & 930418 & 33.19 & 38.21 & -5.0 \\
\hline 14S17W05CAD1 & 333238 & 925255 & 36.25 & 37.24 & -1.0 \\
\hline 14S17W32CAD1 & 332803 & 925251 & 82.3 & 79.06 & 3.2 \\
\hline 14S19W29ABB1 & 332941 & 930513 & 85.73 & 88.16 & -2.4 \\
\hline 15S15W32DBB2 & 332234 & 924027 & 174.58 & 169.42 & 5.2 \\
\hline 15S18W36ADD1 & 332311 & 925436 & 95.1 & 94.4 & 0.7 \\
\hline 15S19W10DCC1 & 332618 & 930318 & 70.85 & 69.86 & 1.0 \\
\hline 15S19W21CDD2 & 332438 & 930432 & 194.69 & 198.82 & -4.1 \\
\hline \multicolumn{6}{|c|}{ Phillips County } \\
\hline 01S02E32DDC1 & 343324 & 905455 & 80.73 & 84.17 & -3.4 \\
\hline 02S02E01ADC1 & 343323 & 905056 & 37.88 & 35.17 & 2.7 \\
\hline 02S04E02DBA1 & 343243 & 903907 & 113.3 & 129.19 & -15.9 \\
\hline 02S05E16BCB1 & 343108 & 903526 & 32.02 & 35.11 & -3.1 \\
\hline 02S05E29CCC1 & 342851 & 903635 & 33.81 & 23.56 & 10.3 \\
\hline 03S03E30DAA1 & 342403 & 904915 & 44.69 & 35.05 & 9.6 \\
\hline 04S02E25CCC1 & 341824 & 905121 & 36.37 & 37.67 & -1.3 \\
\hline \multicolumn{6}{|c|}{ Poinsett County } \\
\hline 10N01E12BDC1 & 353026 & 905630 & 94.51 & 100.38 & -5.9 \\
\hline 10N01E15DBB1 & 352931 & 905825 & 93.82 & 96.92 & -3.1 \\
\hline 10N01E33ABA1 & 352725 & 905924 & 74.66 & 79.5 & -4.8 \\
\hline 10N03E02BCD1 & 353139 & 904447 & 109.75 & 111.68 & -1.9 \\
\hline 10N03E23CAC1 & 352850 & 904432 & 111.13 & 113.12 & -2.0 \\
\hline 11N02E16CCC1 & 353448 & 905321 & 104.24 & 108.69 & -4.5 \\
\hline 11N03E25BDD1 & 353325 & 904323 & 119.68 & 121.45 & -1.8 \\
\hline 12N03E12BBB1 & 354137 & 904340 & 93.76 & 112.28 & -18.5 \\
\hline 12N03E35BCC1 & 353745 & 904456 & 98.58 & 100.53 & -2.0 \\
\hline 12N03E35DDA1 & 353727 & 904353 & 108.5 & 102.95 & 5.6 \\
\hline \multicolumn{6}{|c|}{ Prairie County } \\
\hline 01N05W19CDC1 & 344113 & 913505 & 141 & 145.15 & -4.2 \\
\hline 01N06W02ABB1 & 344442 & 913701 & 117.54 & 128.34 & -10.8 \\
\hline 01N06W34CBB1 & 343943 & 913846 & 157.19 & 169.7 & -12.5 \\
\hline 01S05W06BCB1 & 343904 & 913532 & 153.77 & 177.2 & -23.4 \\
\hline 01S05W20ABB1 & 343640 & 913352 & 155.61 & 154.65 & 1.0 \\
\hline
\end{tabular}


Appendix 2. Difference in water level from 2003 to 2007 in the Sparta-Memphis aquifer in Arkansas.—Continued

[Horizontal dautm is North American Datum of 1983; Negative values denote a decline, 2003 depth to water level from Schrader (2006)]

\begin{tabular}{|c|c|c|c|c|c|}
\hline Station name & $\begin{array}{l}\text { Latitude } \\
\text { (degrees, } \\
\text { minutes, } \\
\text { seconds) }\end{array}$ & $\begin{array}{c}\text { Longitude } \\
\text { (degrees, } \\
\text { minutes, } \\
\text { seconds) }\end{array}$ & $\begin{array}{c}2003 \text { depth } \\
\text { to water } \\
\text { (feet below land- } \\
\text { surface datum }\end{array}$ & $\begin{array}{c}2007 \text { depth } \\
\text { to water } \\
\text { (feet below land- } \\
\text { surface datum }\end{array}$ & $\begin{array}{c}\text { Difference in } \\
\text { water level from } \\
2003 \text { to } 2007 \\
\text { (feet) }\end{array}$ \\
\hline \multicolumn{6}{|c|}{ Prairie County-Continued } \\
\hline 01S06W11DBD1 & 343749 & 913654 & 169.4 & 177.82 & -8.4 \\
\hline 02N04W19ACB1 & 344649 & 912802 & 89.77 & 66.13 & 23.6 \\
\hline 02N06W19AAB1 & 344718 & 914050 & 142.97 & 150.58 & -7.6 \\
\hline 02N06W20BCB1 & 344707 & 914033 & 139.81 & 147.18 & -7.4 \\
\hline 02N06W21DAD1 & 344644 & 913829 & 121.02 & 132.92 & -11.9 \\
\hline 02N06W22BDD1 & 344654 & 913801 & 127.91 & 127.9 & 0.0 \\
\hline 03N05W03ADA2 & 345452 & 913043 & 59.14 & 59.9 & -0.8 \\
\hline 03N05W20CCC1 & 345145 & 913356 & 70.1 & 71.89 & -1.8 \\
\hline 03N06W20CDD1 & 345140 & 914004 & 84.2 & 85.88 & -1.7 \\
\hline \multicolumn{6}{|c|}{ St. Francis County } \\
\hline 04N04E18BAB1 & 345743 & 904319 & 64.25 & 65.29 & -1.0 \\
\hline 03N01W33CDD1 & 345446 & 910635 & 67.51 & 71.24 & -3.7 \\
\hline \multicolumn{6}{|c|}{ Union County } \\
\hline 16S14W15CAB1 & 331944 & 923218 & 153.21 & 149.7 & 3.5 \\
\hline 16S15W20DAA1 & 331860 & 923958 & 275.89 & 254.7 & 21.2 \\
\hline 16S15W31ACC1 & 331717 & 924129 & 301.68 & 265.72 & 36.0 \\
\hline 16S16W02ABC1 & 332206 & 924329 & 170.9 & 162.53 & 8.4 \\
\hline 16S18W34ABC2 & 331806 & 925709 & 206.35 & 209.53 & -3.2 \\
\hline 17S12W31DDD1 & 331206 & 922226 & 236.9 & 228.07 & 8.8 \\
\hline 17S12W32BBC1 & 331202 & 922219 & 249.08 & 241.54 & 7.5 \\
\hline 17S13W31BAC1 & 331200 & 922916 & 299.97 & 309.04 & -9.1 \\
\hline 17S15W08CDD1 & 331505 & 924027 & 333.65 & 289.65 & 44.0 \\
\hline 17S15W18DBB1 & 331439 & 924129 & 346.83 & 301.33 & 45.5 \\
\hline 17S15W28DBA1 & 331246 & 923910 & 393.19 & 345.83 & 47.4 \\
\hline 17S15W28DCC1 & 331233 & 923924 & 445.2 & 422.88 & 22.3 \\
\hline 17S15W29CDC1 & 331229 & 924039 & 380.4 & 361.79 & 18.6 \\
\hline 17S15W31DCA1 & 331145 & 924117 & 436.69 & 396.61 & 40.1 \\
\hline 17S15W31DDA1 & 331144 & 924105 & 426.27 & 383.42 & 42.9 \\
\hline 17S16W01BAA1 & 331649 & 924233 & 313.1 & 271.73 & 41.4 \\
\hline 17S16W02CCC1 & 331559 & 924403 & 339.93 & 316.37 & 23.6 \\
\hline 17S16W02DCD1 & 331602 & 924326 & 391.78 & 375.78 & 16.0 \\
\hline 17S16W12CDD1 & 331506 & 924232 & 399.07 & 382.38 & 16.7 \\
\hline 17S16W24BDB1 & 331357 & 924248 & 403.82 & 343.85 & 60.0 \\
\hline 17S17W30DCD1 & 331257 & 925356 & 319.4 & 323.53 & -4.1 \\
\hline 18S11W09ABC1 & 331012 & 921443 & 96.15 & 94.64 & 1.5 \\
\hline 18S12W33BBB1 & 330651 & 922120 & 137.32 & 139.56 & -2.2 \\
\hline
\end{tabular}


Appendix 2. Difference in water level from 2003 to 2007 in the Sparta-Memphis aquifer in Arkansas._Continued

[Horizontal dautm is North American Datum of 1983; Negative values denote a decline, 2003 depth to water level from Schrader (2006)]

\begin{tabular}{rccccc}
\hline & $\begin{array}{c}\text { Latitude } \\
\text { (degrees, } \\
\text { minutes, } \\
\text { seconds) }\end{array}$ & $\begin{array}{c}\text { Longitude } \\
\text { (degrees, } \\
\text { minutes, } \\
\text { seconds) }\end{array}$ & $\begin{array}{c}\text { 2003 depth } \\
\text { to water } \\
\text { (feet below land- } \\
\text { surface datum }\end{array}$ & $\begin{array}{c}\text { 2007 depth } \\
\text { to water } \\
\text { (feet below land- } \\
\text { surface datum }\end{array}$ & $\begin{array}{c}\text { Difference in } \\
\text { water level from } \\
\text { 2003 to 2007 } \\
\text { (feet) }\end{array}$ \\
\hline \multicolumn{5}{c}{ Union County-Continued } \\
\hline 18S14W06CCD1 & 331039 & 923531 & 386.17 & 342.8 & 43.4 \\
18S15W33ADA1 & 330659 & 923858 & 372.64 & 359.87 & 12.8 \\
18S15W35DAC1 & 330636 & 923707 & 306.48 & 283.78 & 22.7 \\
18S16W10CDD1 & 331000 & 924445 & 325.82 & 314.68 & 11.1 \\
18S16W11AAB1 & 331041 & 924314 & 379.23 & 337.3 & 41.9 \\
18S16W11DAC1 & 331011 & 924316 & 416.88 & 412.75 & 4.1 \\
18S16W12ACB1 & 331029 & 924232 & 453.75 & 433.04 & 20.7 \\
18S16W28BBB1 & 330809 & 924611 & 329.96 & 319.2 & 10.8 \\
18S17W22BDD1 & 330856 & 925056 & 359.82 & 340.69 & 19.1 \\
18S18W11ACD2 & 331051 & 925615 & 280.7 & 267.28 & 13.4 \\
19S10W16CBC1 & 330329 & 920904 & 84.28 & 88.33 & -4.1 \\
19S11W23ACA1 & 330255 & 921229 & 151.16 & 152.44 & -1.3 \\
19S11W25AAA1 & 330218 & 921113 & 148.02 & 151.2 & -3.2 \\
19S12W13AAA1 & 330411 & 921717 & 154.04 & 142.37 & 11.7 \\
19S16W35DDC1 & 330109 & 924326 & 239.08 & 235.15 & 3.9 \\
19S18W14ADA1 & 330452 & 925608 & 187.6 & 192.57 & -5.0 \\
\hline & & & Woodruff County & & \\
\hline 05N01W11ABA1 & 350426 & 910407 & 56.02 & 60 & -4.0 \\
05N01W17DBB1 & 350311 & 910727 & 45.67 & 47.36 & -1.7 \\
05N02W31DCB3 & 350027 & 911456 & 11.3 & 16.24 & -4.9 \\
06N01W13ABA1 & 350852 & 910254 & 65.36 & 68.46 & -3.1 \\
06N01W13ADC1 & 350827 & 910247 & 67.99 & 68.38 & -0.4 \\
07N01W12BCB1 & 351442 & 910326 & 63.21 & 67.94 & -4.7 \\
08N01W12CDA1 & 351934 & 910311 & 78.37 & 74.86 & 3.5 \\
08N02W26ADC1 & 351726 & 911004 & 34.84 & 33.83 & 1.0 \\
\hline & & & & \\
\hline
\end{tabular}


Appendix 3. Specific conductance, temperature, and chloride data from wells completed in the Sparta-Memphis aquifer in Arkansas, summer 2007.

[Horizontal datum is North American Datum of 1983; $\mu \mathrm{S} / \mathrm{cm}$, microsiemens per centimeter at 25 degrees Celsius; mg/L, milligrams per liter; --, no data]

\begin{tabular}{|c|c|c|c|c|c|c|c|}
\hline Station name & $\begin{array}{c}\text { Latitude } \\
\text { (degrees, } \\
\text { minutes, } \\
\text { seconds) }\end{array}$ & $\begin{array}{c}\text { Longitude } \\
\text { (degrees, } \\
\text { minutes, } \\
\text { seconds) }\end{array}$ & Date & Time & $\begin{array}{c}\text { Temperature } \\
\text { (degrees } \\
\text { Celsius) }\end{array}$ & $\begin{array}{c}\text { Specifc } \\
\text { conductance } \\
(\mu \mathrm{S} / \mathrm{cm})\end{array}$ & $\begin{array}{c}\text { Chloride } \\
\text { dissolved } \\
\text { (mg/L) }\end{array}$ \\
\hline \multicolumn{8}{|c|}{ Arkansas County } \\
\hline 02S04W06CDB1 & 343312 & 912849 & $7 / 31 / 2007$ & 1055 & 23.3 & 466 & -- \\
\hline 02S05W34ABC1 & 342925 & 913147 & $7 / 30 / 2007$ & 1625 & 24.3 & 390 & -- \\
\hline 03S04W26CDA1 & 342421 & 912438 & $7 / 05 / 2007$ & 1100 & 23.7 & 429 & 7.5 \\
\hline 03S05W15CBB1 & 342633 & 913229 & $7 / 30 / 2007$ & 1550 & 24.2 & 330 & 6.5 \\
\hline 03S06W30BBD1 & 342516 & 914216 & $7 / 30 / 2007$ & 1045 & 24.0 & 347 & 12.6 \\
\hline 04S01W04CBD1 & 342225 & 910808 & $7 / 05 / 2007$ & 1230 & 23.2 & 854 & -- \\
\hline 05S03W04ADB1 & 341734 & 912007 & $7 / 03 / 2007$ & 1245 & 23.4 & 393 & 10.4 \\
\hline 06S02W22CDB1 & 340904 & 911331 & $7 / 03 / 2007$ & 1100 & 28.0 & 409 & 13.2 \\
\hline 07S03W06ABC1 & 340702 & 912248 & $7 / 03 / 2007$ & 0805 & 23.6 & 193 & -- \\
\hline 08S02W09BCC1 & 340031 & 911448 & $7 / 03 / 2007$ & 1015 & 24.6 & 238 & 8.7 \\
\hline \multicolumn{8}{|c|}{ Ashley County } \\
\hline 15S07W32CDD1 & 332118 & 915101 & $6 / 22 / 2007$ & 0700 & 23.4 & 875 & 35.2 \\
\hline \multicolumn{8}{|c|}{ Bradley County } \\
\hline 13S09W06ACB2 & 333647 & 920417 & $6 / 25 / 2007$ & 1610 & 26.7 & 362 & 11.4 \\
\hline 13S09W06BDC1 & 333649 & 920406 & $6 / 25 / 2007$ & 1650 & 27.1 & 390 & -- \\
\hline 13S11W17BCD1 & 333454 & 921607 & $6 / 25 / 2007$ & 1510 & 25.6 & 419 & -- \\
\hline 14S09W16AAC1 & 332931 & 920218 & $6 / 25 / 2007$ & 1730 & 25.6 & 499 & -- \\
\hline \multicolumn{8}{|c|}{ Calhoun County } \\
\hline 11S14W12CAC3 & 334630 & 922928 & $6 / 21 / 2007$ & 1320 & 21.6 & 189 & 12.5 \\
\hline 11S14W13BAA1 & 334616 & 922922 & $6 / 21 / 2007$ & 1300 & 19.5 & 124 & -- \\
\hline 13S13W32CDA1 & 333227 & 922742 & $6 / 21 / 2007$ & 1400 & 22.1 & 431 & 23.8 \\
\hline 13S15W36CBD1 & 333227 & 923532 & $6 / 21 / 2007$ & 1430 & 24.8 & 282 & 8.4 \\
\hline 14S13W12CCB1 & 333040 & 922404 & $7 / 23 / 2007$ & 1030 & 24.3 & 431 & 14.6 \\
\hline 14S15W16BAA1 & 333055 & 923912 & $6 / 21 / 2007$ & 1520 & 26.9 & 688 & 76.7 \\
\hline \multicolumn{8}{|c|}{ Cleveland County } \\
\hline 09S09W04BBD1 & 335820 & 920237 & $7 / 02 / 2007$ & 1640 & 25.6 & 174 & -- \\
\hline 09S11W01DCA1 & 335729 & 921134 & $7 / 02 / 2007$ & 1700 & 24.2 & 282 & 3.3 \\
\hline 10S09W23CDC1 & 334918 & 920021 & $7 / 02 / 2007$ & 1605 & 27.0 & 224 & -- \\
\hline 10S09W35ACD1 & 334758 & 915957 & $7 / 02 / 2007$ & 1545 & 25.0 & 234 & 2.2 \\
\hline 11S11W16AAB1 & 334543 & 921423 & $7 / 02 / 2007$ & 1510 & 26.2 & 366 & 5.7 \\
\hline \multicolumn{8}{|c|}{ Columbia County } \\
\hline 15S20W20CCB1 & 332453 & 931215 & $6 / 19 / 2007$ & 1440 & 23.3 & 314 & 5.0 \\
\hline 16S20W18ACD1 & 332053 & 931237 & $6 / 19 / 2007$ & 1410 & 23.6 & 356 & 4.5 \\
\hline 17S19W15AAB1 & 331546 & 930318 & $6 / 19 / 2007$ & 1505 & 23.4 & 421 & 9.3 \\
\hline
\end{tabular}


Appendix 3. Specific conductance, temperature, and chloride data from wells completed in the Sparta-Memphis aquifer in Arkansas, summer 2007.-Continued

[Horizontal datum is North American Datum of $1983 ; \mu \mathrm{S} / \mathrm{cm}$, microsiemens per centimeter at 25 degrees Celsius; mg/L, milligrams per liter; --, no data]

\begin{tabular}{|c|c|c|c|c|c|c|c|}
\hline Station name & $\begin{array}{c}\text { Latitude } \\
\text { (degrees, } \\
\text { minutes, } \\
\text { seconds) }\end{array}$ & $\begin{array}{c}\text { Longitude } \\
\text { (degrees, } \\
\text { minutes, } \\
\text { seconds) }\end{array}$ & Date & Time & $\begin{array}{c}\text { Temperature } \\
\text { (degrees } \\
\text { Celsius) }\end{array}$ & $\begin{array}{c}\text { Specifc } \\
\text { conductance } \\
(\mu \mathrm{S} / \mathrm{cm})\end{array}$ & $\begin{array}{c}\text { Chloride } \\
\text { dissolved } \\
\text { (mg/L) }\end{array}$ \\
\hline \multicolumn{8}{|c|}{ Columbia County-Continued } \\
\hline 17S20W17CDA1 & 331520 & 931201 & $7 / 23 / 2007$ & 1410 & 23.7 & 383 & 8.2 \\
\hline 18S20W06DDC1 & 331143 & 931249 & $6 / 19 / 2007$ & 1300 & 22.8 & 297 & 3.8 \\
\hline 18S20W18ABD1 & 331039 & 931255 & $6 / 19 / 2007$ & 1235 & 24.3 & 262 & 3.1 \\
\hline 18S21W17ACD1 & 331034 & 931759 & $6 / 19 / 2007$ & 1115 & 22.0 & 232 & 2.4 \\
\hline 18S22W27DDD1 & 330835 & 932159 & $6 / 19 / 2007$ & 1200 & 21.6 & 215 & 3.3 \\
\hline 19S20W09CBD1 & 330555 & 931129 & $7 / 23 / 2007$ & 1440 & 23.6 & 229 & 3.1 \\
\hline 19S23W11CDA2 & 330609 & 932744 & $6 / 19 / 2007$ & 0800 & 21.8 & 178 & 3.7 \\
\hline 19S23W11DDB1 & 330605 & 932722 & $6 / 19 / 2007$ & 0820 & 19.4 & 189 & 4.5 \\
\hline \multicolumn{8}{|c|}{ Crittenden County } \\
\hline 06N09E23AAB1 & 350745 & 900553 & $8 / 16 / 2007$ & 1600 & 24.5 & 254 & 23.3 \\
\hline \multicolumn{8}{|c|}{ Cross County } \\
\hline 07N05E04ADD1 & 351538 & 903330 & $8 / 16 / 2007$ & 1130 & 21.6 & 190 & 2.6 \\
\hline 09N03E22AAB2 & 352404 & 904518 & $8 / 16 / 2007$ & 0900 & 19.0 & 335 & 3.2 \\
\hline 09N03E22AAD1 & 352403 & 904512 & $8 / 16 / 2007$ & 0840 & 19.6 & 333 & 3.6 \\
\hline 09N04E30DCA1 & 352232 & 904218 & $8 / 16 / 2007$ & 0930 & 22.6 & 459 & 3.1 \\
\hline 09N04E30DCA1 & 352232 & 904218 & $8 / 22 / 2007$ & 0911 & 23.9 & 449 & 3.1 \\
\hline \multicolumn{8}{|c|}{ Dallas County } \\
\hline 07S14W31AAA1 & 340425 & 923334 & $6 / 18 / 2007$ & 0940 & 24.1 & 129 & 7.7 \\
\hline 08S16W18ACC1 & 340152 & 924639 & $6 / 18 / 2007$ & 1235 & 21.4 & 41 & 4.8 \\
\hline 09S16W19CAA1 & 335605 & 924701 & $6 / 18 / 2007$ & 1200 & 21.8 & 268 & 6.2 \\
\hline 10S13W34ACA1 & 334832 & 922455 & $6 / 18 / 2007$ & 1040 & 24.6 & 263 & -- \\
\hline 10S14W27CDB1 & 334908 & 923138 & $6 / 18 / 2007$ & 1105 & 24.7 & 268 & 11.6 \\
\hline \multicolumn{8}{|c|}{ Desha County } \\
\hline 09S02W26AAC1 & 335346 & 911521 & $6 / 27 / 2007$ & 1210 & 23.8 & 244 & 9.7 \\
\hline 10S04W11CBC1 & 335034 & 912905 & $6 / 27 / 2007$ & 1500 & 27.0 & 249 & -- \\
\hline 11S01W31BBB1 & 334225 & 911415 & $6 / 27 / 2007$ & 1130 & 24.1 & 317 & -- \\
\hline 12S01W32CDB1 & 333629 & 911244 & $6 / 27 / 2007$ & 0740 & 22.0 & 353 & 13.3 \\
\hline 12S03W26CBB1 & 333749 & 912259 & $6 / 27 / 2007$ & 0955 & 25.4 & 411 & -- \\
\hline 12S03W34DAD1 & 333643 & 912305 & $6 / 27 / 2007$ & 1015 & 25.3 & 475 & -- \\
\hline \multicolumn{8}{|c|}{ Drew County } \\
\hline 11S05W21CDC1 & 334352 & 913724 & $6 / 26 / 2007$ & 1545 & 22.7 & 294 & 3.8 \\
\hline 11S07W22BBC1 & 334450 & 914905 & $6 / 26 / 2007$ & 1500 & 26.6 & 205 & 1.9 \\
\hline 12S06W30BBD1 & 333807 & 914543 & $6 / 26 / 2007$ & 1420 & 25.2 & 264 & 4.2 \\
\hline 13S05W36ACB1 & 333151 & 913408 & $6 / 26 / 2007$ & 1330 & 22.4 & 282 & -- \\
\hline
\end{tabular}


Appendix 3. Specific conductance, temperature, and chloride data from wells completed in the Sparta-Memphis aquifer in Arkansas, summer 2007.-Continued

[Horizontal datum is North American Datum of 1983; $\mu \mathrm{S} / \mathrm{cm}$, microsiemens per centimeter at 25 degrees Celsius; mg/L, milligrams per liter; --, no data]

\begin{tabular}{|c|c|c|c|c|c|c|c|}
\hline Station name & $\begin{array}{l}\text { Latitude } \\
\text { (degrees, } \\
\text { minutes, } \\
\text { seconds) }\end{array}$ & $\begin{array}{c}\text { Longitude } \\
\text { (degrees, } \\
\text { minutes, } \\
\text { seconds) }\end{array}$ & Date & Time & $\begin{array}{c}\text { Temperature } \\
\text { (degrees } \\
\text { Celsius) }\end{array}$ & $\begin{array}{c}\text { Specifc } \\
\text { conductance } \\
(\mu \mathrm{S} / \mathrm{cm})\end{array}$ & $\begin{array}{c}\text { Chloride } \\
\text { dissolved } \\
\text { (mg/L) }\end{array}$ \\
\hline \multicolumn{8}{|c|}{ Jefferson County } \\
\hline 03S10W27AAD1 & 342502 & 920434 & $8 / 07 / 2007$ & 0840 & 22.8 & 87 & 2.5 \\
\hline 03S11W22ABC1 & 342651 & 921058 & $8 / 07 / 2007$ & 1305 & 25.7 & 121 & 7.4 \\
\hline 04S07W17BCC1 & 342140 & 914742 & $8 / 03 / 2007$ & 0900 & 24.4 & 142 & 4.5 \\
\hline 04S08W35BBD1 & 341909 & 915056 & $8 / 03 / 2007$ & 0930 & 24.1 & 146 & 1.5 \\
\hline 04S11W14BAD1 & 342220 & 921000 & $8 / 07 / 2007$ & 1145 & 24.6 & 82 & -- \\
\hline 04S11W14BCA1 & 342218 & 921015 & $8 / 07 / 2007$ & 1125 & 24.6 & 86 & 3.2 \\
\hline 05S09W31DDC1 & 341337 & 920109 & $8 / 07 / 2007$ & 1530 & 30.0 & 131 & 2.2 \\
\hline 05S10W16CAA1 & 341637 & 920545 & $8 / 07 / 2007$ & 1025 & 25.3 & 95 & -- \\
\hline 06S09W17CAD1 & 341159 & 920207 & $8 / 07 / 2007$ & 1450 & 26.6 & 141 & 1.7 \\
\hline 06S10W23ACA2 & 341123 & 920504 & 8/07/2007 & 1435 & 23.5 & 178 & -- \\
\hline 06S10W23ACD1 & 341116 & 920508 & $8 / 07 / 2007$ & 1415 & 23.7 & 129 & -- \\
\hline 06S10W23DBA1 & 341105 & 920506 & $8 / 07 / 2007$ & 1400 & 27.4 & 166 & 1.9 \\
\hline \multicolumn{8}{|c|}{ Lafayette County } \\
\hline 19S23W29BDB1 & 330352 & 933103 & $6 / 19 / 2007$ & 0900 & 24.0 & 252 & -- \\
\hline 20S23W05ADB 1 & 330223 & 933036 & $6 / 19 / 2007$ & 0920 & 26.3 & 275 & 6.3 \\
\hline \multicolumn{8}{|c|}{ Lincoln County } \\
\hline 07S06W33BAA1 & 340445 & 914140 & $6 / 28 / 2007$ & 0830 & 24.8 & 200 & -- \\
\hline 07S07W30CDC1 & 340444 & 915043 & $6 / 28 / 2007$ & 1315 & 29.8 & 211 & 1.2 \\
\hline 08S04W22AAA1 & 340105 & 912753 & $6 / 28 / 2007$ & 0945 & 25.7 & 204 & -- \\
\hline 08S05W03BAA2 & 340310 & 913454 & $6 / 28 / 2007$ & 0915 & 24.5 & 209 & 4.5 \\
\hline 08S05W35ACC1 & 335907 & 913337 & $6 / 28 / 2007$ & 0740 & 23.4 & 237 & 6.1 \\
\hline 08S05W35ACC1 & 335907 & 913337 & $6 / 28 / 2007$ & 1115 & 25.8 & 308 & -- \\
\hline 08S08W35DBB1 & 335858 & 915222 & $6 / 28 / 2007$ & 1400 & 27.0 & 201 & -- \\
\hline 08S08W35DCB1 & 335851 & 915217 & $6 / 28 / 2007$ & 1435 & 27.7 & 202 & 1.4 \\
\hline 09S07W07DAD1 & 335634 & 915128 & $6 / 28 / 2007$ & 1235 & 24.9 & 204 & 1.4 \\
\hline \multicolumn{8}{|c|}{ Lonoke County } \\
\hline 02N07W09AAA1 & 344906 & 914500 & $8 / 01 / 2007$ & 1005 & 20.4 & 374 & -- \\
\hline 02N07W32DDD1 & 344453 & 914619 & $7 / 10 / 2007$ & 1337 & 20.2 & 471 & 7.9 \\
\hline 02N07W32DDD1 & 344453 & 914619 & $7 / 31 / 2007$ & 1445 & 19.9 & 464 & 7.9 \\
\hline 02N08W20BCA1 & 344710 & 915330 & $8 / 01 / 2007$ & 0915 & 19.8 & 567 & 78.3 \\
\hline 02N08W20BCD1 & 344708 & 915335 & $7 / 08 / 2007$ & 0940 & 19.5 & 575 & 76.8 \\
\hline 03N08W23DDD1 & 345152 & 915025 & $8 / 01 / 2007$ & 1145 & 19.3 & 407 & 24.5 \\
\hline \multicolumn{8}{|c|}{ Monroe County } \\
\hline 01N03W14CCB1 & 344144 & 911801 & $8 / 13 / 2007$ & 1130 & 23.5 & 892 & 162 \\
\hline 01S02W22ADB1 & 343601 & 911158 & $8 / 13 / 2007$ & 1615 & 21.6 & 731 & 66.1 \\
\hline
\end{tabular}


Appendix 3. Specific conductance, temperature, and chloride data from wells completed in the Sparta-Memphis aquifer in Arkansas, summer 2007.-Continued

[Horizontal datum is North American Datum of 1983; $\mu \mathrm{S} / \mathrm{cm}$, microsiemens per centimeter at 25 degrees Celsius; mg/L, milligrams per liter; --, no data]

\begin{tabular}{|c|c|c|c|c|c|c|c|}
\hline Station name & $\begin{array}{c}\text { Latitude } \\
\text { (degrees, } \\
\text { minutes, } \\
\text { seconds) }\end{array}$ & $\begin{array}{c}\text { Longitude } \\
\text { (degrees, } \\
\text { minutes, } \\
\text { seconds) }\end{array}$ & Date & Time & $\begin{array}{c}\text { Temperature } \\
\text { (degrees } \\
\text { Celsius) }\end{array}$ & $\begin{array}{c}\text { Specifc } \\
\text { conductance } \\
(\mu \mathrm{S} / \mathrm{cm})\end{array}$ & $\begin{array}{c}\text { Chloride } \\
\text { dissolved } \\
\text { (mg/L) }\end{array}$ \\
\hline \multicolumn{8}{|c|}{ Monroe County-Continued } \\
\hline 03N02W31ADD2 & 345008 & 911439 & $8 / 13 / 2007$ & 1400 & 20.1 & 1,280 & -- \\
\hline 04N02W30BAD1 & 345617 & 911515 & $8 / 13 / 2007$ & 1400 & 20.1 & 1,280 & 308 \\
\hline \multicolumn{8}{|c|}{ Nevada County } \\
\hline 14S21W04CCB1 & 333251 & 931708 & $6 / 18 / 2007$ & 1500 & 20.8 & 159 & 3.8 \\
\hline 14S21W20AAB1 & 333050 & 931723 & $6 / 18 / 2007$ & 1520 & 19.6 & 166 & 4.8 \\
\hline \multicolumn{8}{|c|}{ Ouachita County } \\
\hline \multicolumn{8}{|l|}{ 12S16W26B } \\
\hline AA1 & 333948 & 924304 & $7 / 23 / 2007$ & 1145 & 22.7 & 250 & 6.8 \\
\hline 12S19W14AAA1 & 334143 & 930105 & $6 / 21 / 2007$ & 0915 & 19.6 & 35 & 2.4 \\
\hline 13S16W28ADD1 & 333416 & 924451 & $6 / 21 / 2007$ & 1145 & 22.4 & 591 & 84.4 \\
\hline 13S19W28BCD1 & 333434 & 930418 & $6 / 21 / 2007$ & 1000 & 21.5 & 109 & 3.7 \\
\hline 15S18W36ADD1 & 332311 & 925436 & $6 / 21 / 2007$ & 1040 & 24.4 & 281 & 31.7 \\
\hline 15S19W10DCC1 & 332618 & 930318 & $6 / 21 / 2007$ & 0810 & 21.7 & 186 & 5.0 \\
\hline \multicolumn{8}{|c|}{ Phillips County } \\
\hline 01S02E32DDC1 & 343324 & 905455 & $8 / 14 / 2007$ & 0920 & 21.2 & 792 & 37.4 \\
\hline 01S03E34DDC1 & 343323 & 904621 & $8 / 14 / 2007$ & 1015 & 20.2 & 629 & 3.7 \\
\hline 02S02E01ADC1 & 343323 & 905056 & $8 / 14 / 2007$ & 1045 & 22.7 & 871 & 70.4 \\
\hline 02S04E01CBB1 & 343244 & 903842 & $8 / 14 / 2007$ & 1115 & 21.2 & 767 & 17.4 \\
\hline 02S04E02CBC1 & 343243 & 903846 & $8 / 14 / 2007$ & 1135 & 20.8 & 779 & 25.2 \\
\hline 03S03E30DAA1 & 342403 & 904915 & $8 / 14 / 2007$ & 1540 & 23.0 & 880 & 51.3 \\
\hline 03S05E05BAB1 & 342755 & 903621 & $8 / 14 / 2007$ & 1250 & 21.9 & 694 & 22.4 \\
\hline 04S02E25CCC1 & 341824 & 905121 & $8 / 14 / 2007$ & 1340 & 23.7 & 1,100 & 166 \\
\hline \multicolumn{8}{|c|}{ Prairie County } \\
\hline 02N06W08CD1 & 344810 & 914011 & $8 / 02 / 2007$ & 1400 & 20.4 & 391 & 9.7 \\
\hline \multicolumn{8}{|c|}{ St. Francis County } \\
\hline 05N03E33ABA1 & 350025 & 904708 & $8 / 15 / 2007$ & 0730 & 19.0 & 603 & 15.7 \\
\hline 05N03E33ABA2 & 350020 & 904713 & $8 / 15 / 2007$ & 0800 & 18.3 & 613 & 10.5 \\
\hline 05N03E33ABA3 & 350020 & 904711 & $8 / 15 / 2007$ & 0830 & 18.9 & 542 & 16.6 \\
\hline \multicolumn{8}{|c|}{ Union County } \\
\hline 16S14W15CAB1 & 331944 & 923218 & $6 / 19 / 2007$ & 1730 & 21.4 & 448 & 30.2 \\
\hline 16S15W20DAA1 & 331860 & 923958 & $6 / 19 / 2007$ & 1635 & 24.1 & 492 & 33.1 \\
\hline 16S16W01DDD1 & 332114 & 924211 & $7 / 24 / 2007$ & 1010 & 21.5 & 454 & 20.7 \\
\hline 16S18W34ABC2 & 331806 & 925709 & $6 / 19 / 2007$ & 1555 & 23.4 & 318 & 5.9 \\
\hline 17S12W32BBC1 & 331202 & 922219 & $6 / 20 / 2007$ & 0900 & 25.7 & 864 & 125 \\
\hline 17S13W31BAC1 & 331200 & 922916 & $6 / 20 / 2007$ & 0805 & 25.5 & 727 & 94.8 \\
\hline
\end{tabular}


Appendix 3. Specific conductance, temperature, and chloride data from wells completed in the Sparta-Memphis aquifer in Arkansas, summer 2007.-Continued

[Horizontal datum is North American Datum of 1983; $\mu \mathrm{S} / \mathrm{cm}$, microsiemens per centimeter at 25 degrees Celsius; mg/L, milligrams per liter; --, no data]

\begin{tabular}{|c|c|c|c|c|c|c|c|}
\hline Station name & $\begin{array}{c}\text { Latitude } \\
\text { (degrees, } \\
\text { minutes, } \\
\text { seconds) }\end{array}$ & $\begin{array}{c}\text { Longitude } \\
\text { (degrees, } \\
\text { minutes, } \\
\text { seconds) }\end{array}$ & Date & Time & $\begin{array}{c}\text { Temperature } \\
\text { (degrees } \\
\text { Celsius) }\end{array}$ & $\begin{array}{c}\text { Specifc } \\
\text { conductance } \\
(\mu \mathrm{S} / \mathrm{cm})\end{array}$ & $\begin{array}{c}\text { Chloride } \\
\text { dissolved } \\
\text { (mg/L) }\end{array}$ \\
\hline 17S13W31BAD1 & 331204 & 922907 & $7 / 24 / 2007$ & 1225 & 26.7 & 736 & 94.2 \\
\hline \multicolumn{8}{|c|}{ Union County-Continued } \\
\hline 17S16W24BDB1 & 331357 & 924248 & $7 / 24 / 2007$ & 0720 & 21.8 & 427 & 22.6 \\
\hline 17S17W30DCD1 & 331257 & 925356 & $7 / 23 / 2007$ & 1530 & 20.6 & 318 & 9.4 \\
\hline 18S14W06CCD1 & 331039 & 923531 & $6 / 20 / 2007$ & 1450 & 25.9 & 720 & 84.3 \\
\hline 18S15W33ADA1 & 330659 & 923858 & $6 / 20 / 2007$ & 1405 & 27.0 & 635 & 89.2 \\
\hline 18S15W35DAC1 & 330636 & 923707 & $6 / 20 / 2007$ & 1300 & 24.2 & 703 & 99.3 \\
\hline 18S16W11DAC1 & 331011 & 924316 & $6 / 20 / 2007$ & 1200 & 24.1 & 530 & 33.3 \\
\hline 18S16W12ACB1 & 331029 & 924232 & $6 / 20 / 2007$ & 1000 & 22.9 & 565 & 31 \\
\hline 18S16W28BBB1 & 330809 & 924611 & $6 / 20 / 2007$ & 1115 & 23.6 & 537 & 26.6 \\
\hline 18S18W11ACD2 & 331051 & 925615 & $6 / 20 / 2007$ & 1535 & 25.8 & 351 & 12.6 \\
\hline 19S11W25AAA1 & 330218 & 921113 & $7 / 25 / 2007$ & 1005 & 23.4 & 1,120 & 216 \\
\hline 19S16W35DDC1 & 330109 & 924326 & $7 / 24 / 2007$ & 1315 & 24.0 & 574 & 96.5 \\
\hline
\end{tabular}

Publishing support provided by:

Lafayette and Rolla Publishing Service Centers

For more information concerning the research described in the report:

U.S. Geological Survey

Arkansas Water Science Center

401 Hardin Road

Little Rock, AR 72211-3528

(501) 228-3600

http://ar.water.usgs.gov 


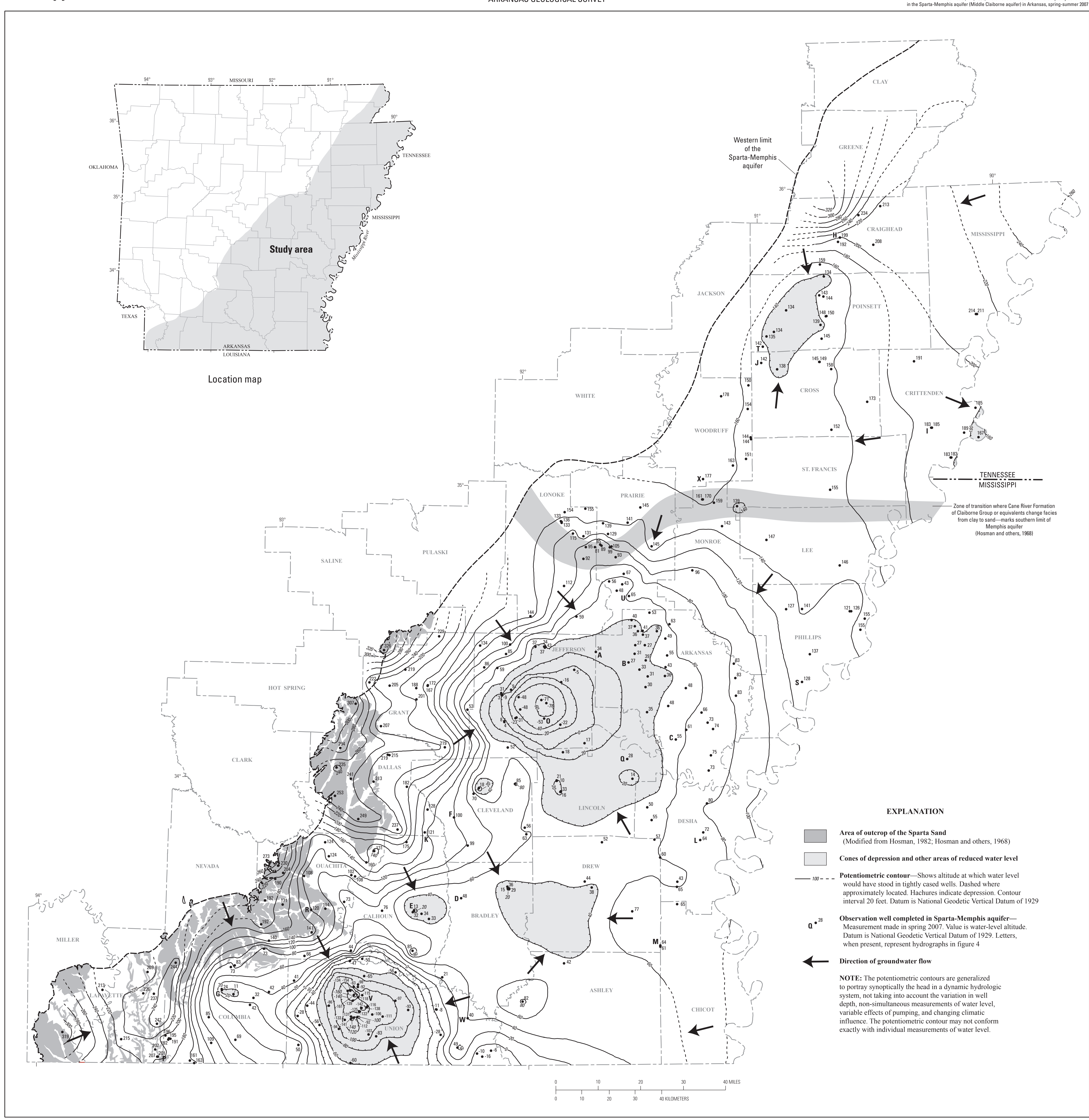

Potentiometric Surface for the Sparta-Memphis Aquifer in Arkansas, 2007 


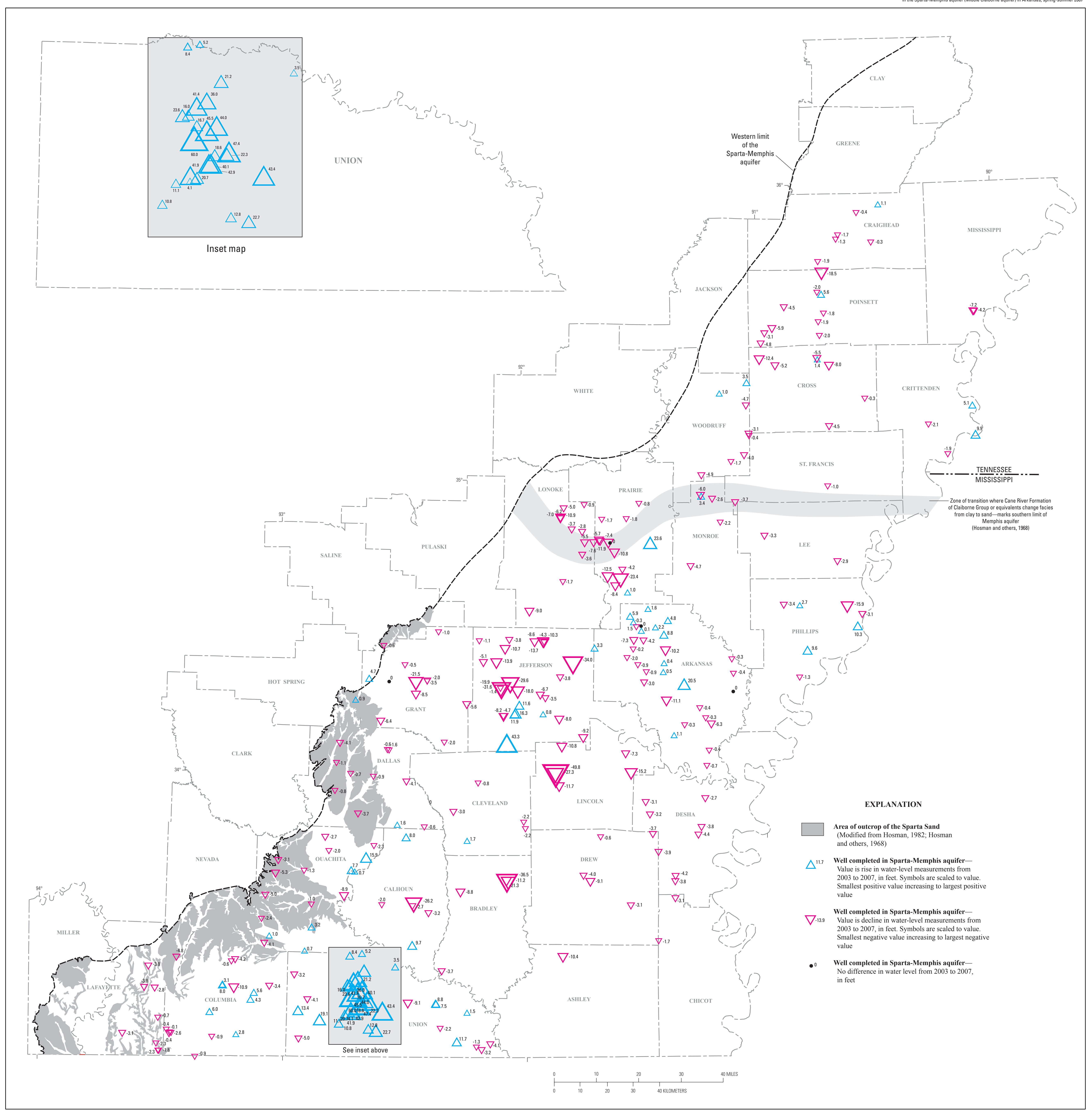

Water-Level Difference for the Sparta-Memphis Aquifer in Arkansas from 2003 to 2007 


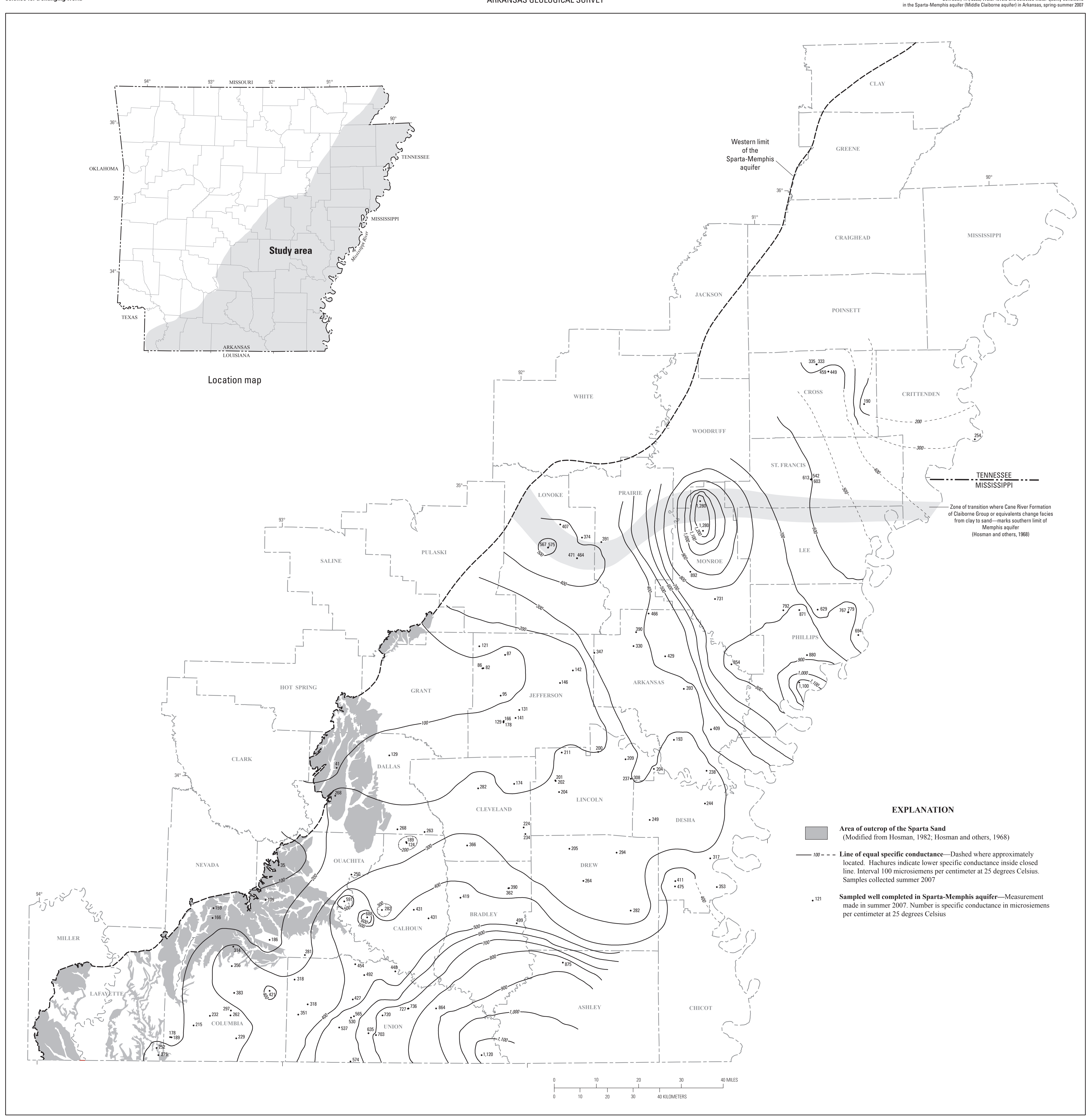

Specific Conductance for the Sparta-Memphis Aquifer in Arkansas, 2007 
